\title{
STATISTICAL EVALUATION OF SHEAR STRENGTH PARAMETERS OF FINE GRAINED TILLS
}

\author{
By \\ Chandra Prakash Poudyal \\ B. Sc (Geology), Tribhuvan University, Nepal, 1997 \\ M. Sc. (Geology), Tribhuvan University, Nepal, 2001 \\ PhD. (Geology), Chungnam National University, Korea, 2010
}

\begin{abstract}
A thesis
presented to Ryerson University

in partial fulfillment of the

requirements for the degree of

Master of Applied Science

in the program of

Civil Engineering
\end{abstract}

Toronto, Ontario, Canada, 2018

(C) Chandra Poudyal 2018 


\section{AUTHOR'S DECLARATION FOR ELECTRONIC SUBMISSION OF A THESIS}

I hereby declare that I am the sole author of this thesis. This is a true copy of the thesis, including any required final revisions, as accepted by my examiners.

I authorize Ryerson University to lend this thesis to other institutions or individuals for the purpose of scholarly research.

I further authorize Ryerson University to reproduce this thesis by photocopying or by other means, in total or in part, at the request of other institutions or individuals for the purpose of scholarly research.

I understand that this thesis may be made available electronically to the public. 


\title{
STATISTICAL EVALUATION OF SHEAR STRENGTH PARAMETERS OF FINE GRAINED TILLS
}

\author{
Chandra Prakash Poudyal \\ Master of Applied Science, 2018 \\ Department of Civil Engineering \\ Ryerson University, Toronto, Canada
}

\section{ABSTRACT}

A statistical analysis is conducted in this study on the shear strength parameters of fine-grained tills from a series of consolidated undrained triaxial tests performed for a light rail transit project in the City of Toronto. Three different failure criteria are applied: the maximum stress ratio, the maximum deviator stress, and the residual stress. Three methods generate only minimal difference in the shear failure angle and a slight difference in cohesion. The friction angle calculated using the maximum stress ratio method ranges from 18.6 to 35.26 degrees compared with values ranging from 18.5 to 34.26 degrees by the maximum deviator stress method. The undrained shear modulus calculated from one-third and two-third peak deviator stress points generate a wide variation from $2 \mathrm{MPa}$ to $167 \mathrm{MPa}$ with an average value of $34 \mathrm{MPa}$. 


\section{ACKNOWLEDGEMENTS}

First, I am grateful to Dr. Jinyuan Liu for giving me the opportunity to do research as a MASc student in Civil Engineering. Dr. Liu did not provide just academic knowledge but he also shared valuable advice and guidance throughout the research and on tackling difficulties during the whole study period. His experiences and engineering intuition along with the new ideas, novel approaches and strong work ethic has encouraged me and inspired my growth as a student and researcher in the geotechnical engineering field. I gratefully acknowledge Dr. Liu for his assistance and guidance to complete this thesis.

Next, I would like to give thanks and gratitude to Dr. Laifa Cao for his great suggestions on the research approach. Many thanks go to the Head of the Department of Civil Engineering and Graduate Program Director, for making all the necessary arrangement to carry out the project. I must also thank Metrolinx and SPL Consultants Limited for granting permission to study the ECLRT project data.

Furthermore, I would like to thank my friends Mr. Markus Jesswein, Mr. Shuihan Li, Mr. Ali Ahmad, Mr. Cong Shi, Mr. Mohammad Afroz, and Mr. Alexender for their help and valuable suggestions on data processing and presenting.

Last but not least, thanks to my wife LAXMI and my children PRADEEPTI and PRANJAL for their endless support, love, encouragement, and patience throughout my educational career at Ryerson University. 


\section{TABLE OF CONTENTS}

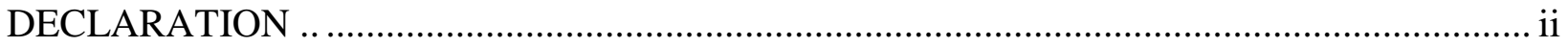

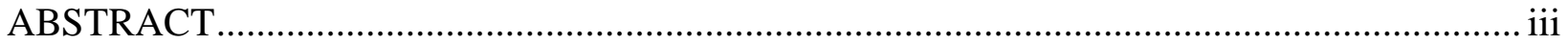

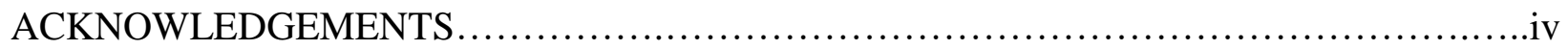

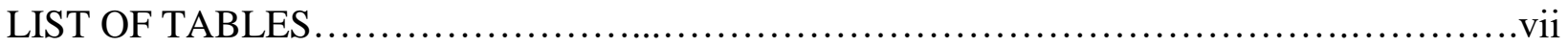

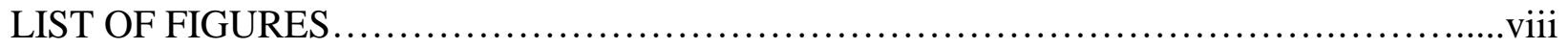

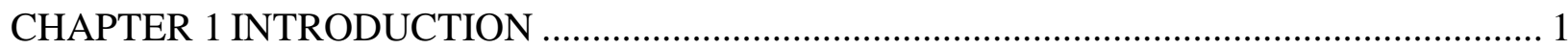

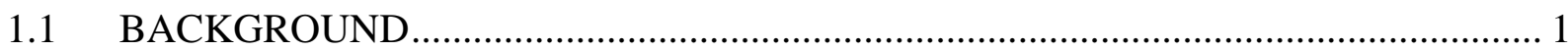

1.2 RELIABILITY BASED GEOTECHNICAL DESIGN …………................................ 3

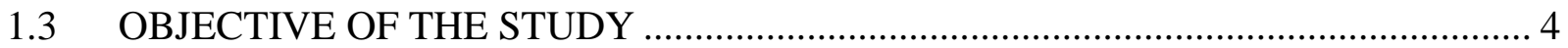

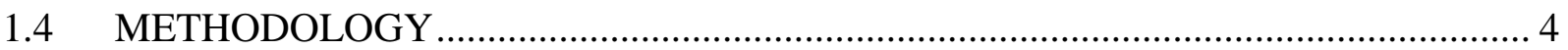

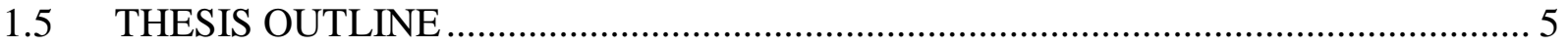

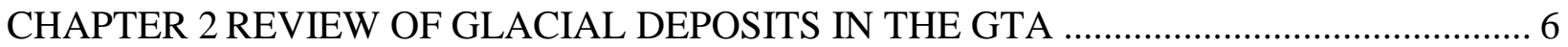

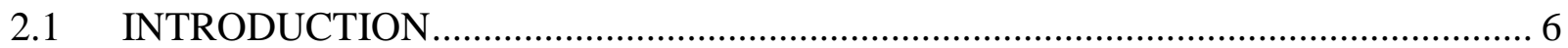

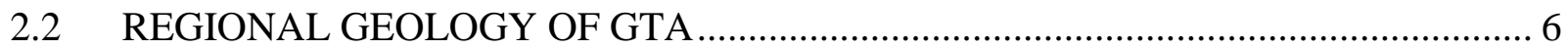

2.3 ENGINEERING BACKGROUND OF THE STUDY ……………………….......... 7

2.4 ENGINEERING PROPERTIES OF GLACIAL TILLS ........................................... 8

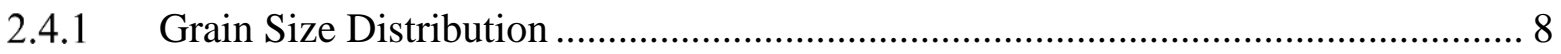

2.4.2 Water Content and Unit Weight ……………................................................... 14

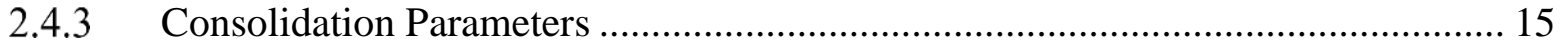

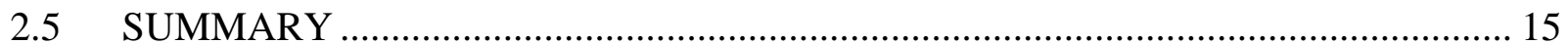

CHAPTER 3 SHEAR STRENGTH OF SOIL AND TRIAXIAL TEST ……………................. 16

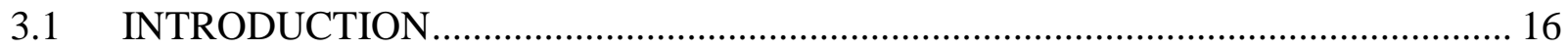

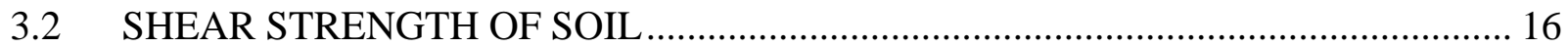

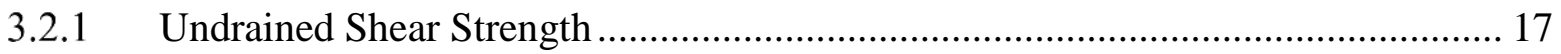

3.2.2 The Principle of Effective Stress ..................................................................... 17

3.3 LABORATORY AND FIELD TESTING TO DETERMINE SHEAR STRENGTH

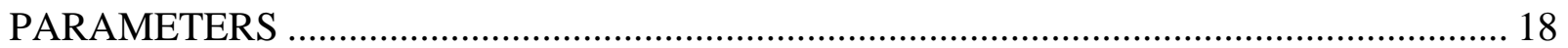

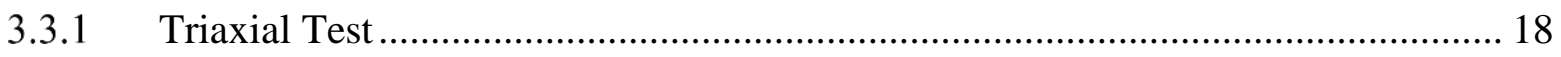

3.3.2 Consolidated Undrained Test.......................................................................... 19 


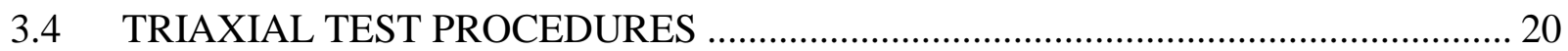

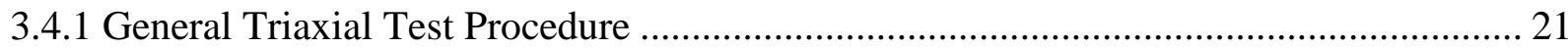

3.5 PRESENTING OF TEST RESULTS FROM TRIAXIAL TESTS ............................... 24

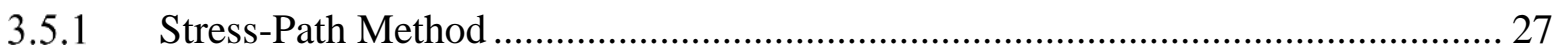

3.6 DETERMINATION OF SHEAR STRENGTH PARAMETERS FROM TRIAXIAL

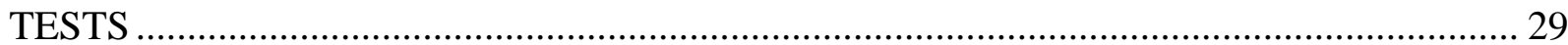

3.6.1 Failure Criterion and Failure Envelope ................................................................ 29

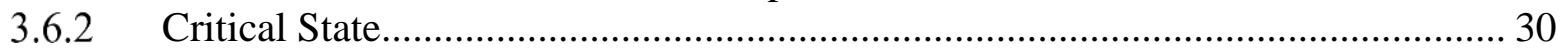

3.6.3 Impact from Different Failure Criteria ………................................................. 33

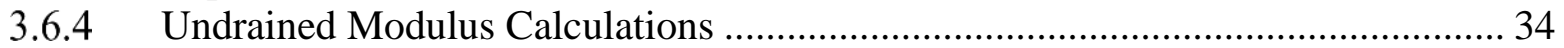

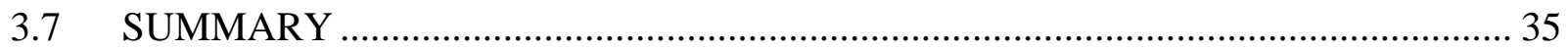

CHAPTER 4 STATISTICAL ANALYSIS OF SHEAR STRENGTH PARAMETERS OF FINE-

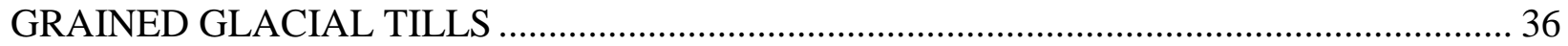

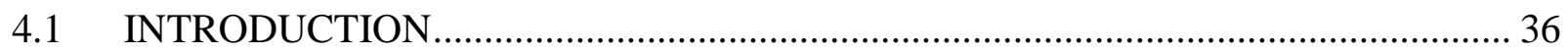

4.1.1 Triaxial Tests Conducted at Don Mills Station ......................................................... 37

4.2 STATISTICAL ANALYSIS OF FINE-GRAINED TILLS IN GTA ............................ 39

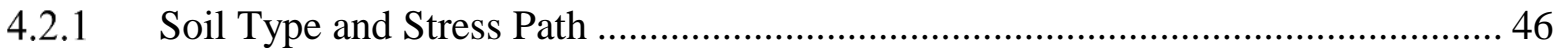

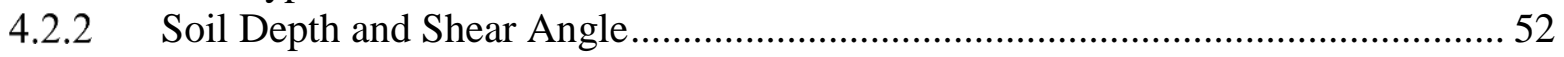

4.2.3 Soil Type and Friction Angle ........................................................................... 52

4.2.4 Shear Bands ............................................................................................. 54

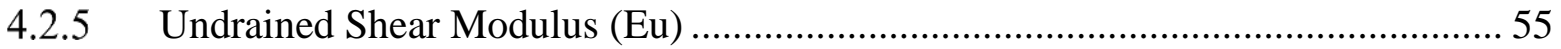

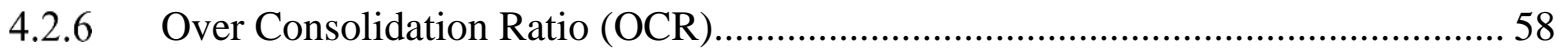

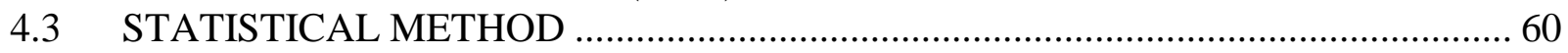

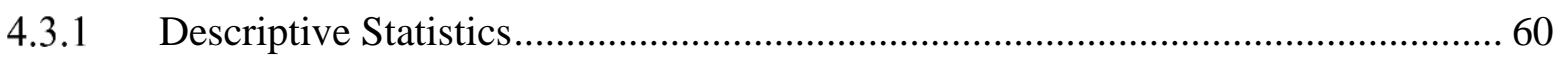

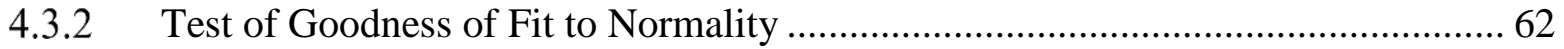

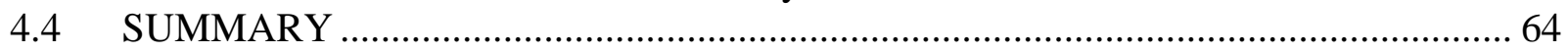

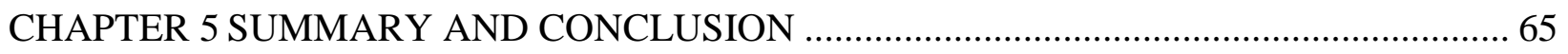

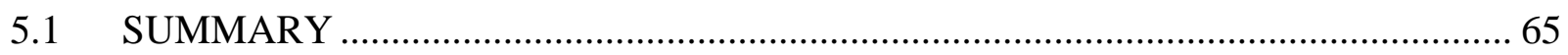

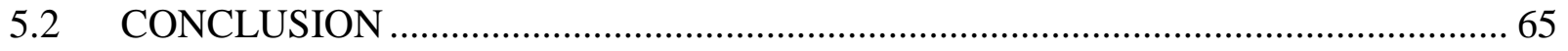

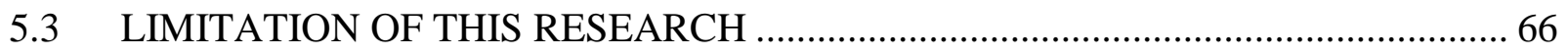

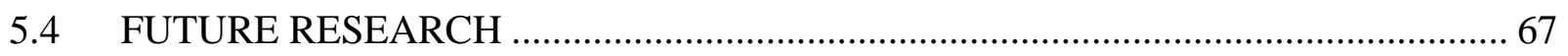

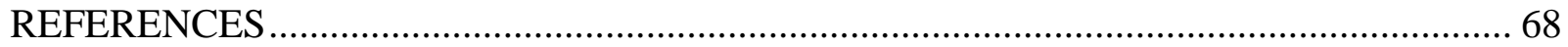




\section{LIST OF TABLES}

Table 3-1 The confining pressure and the failure strain on Black Creek Station 23m depth ....... 27

Table 4-1 Different parameter used to conduct triaxial test of different depth ......................... 37

Table 4-2 Calculation of cohesion (a), friction angle ( $\psi)$ and cohesion ( $\left.c^{\prime}\right)$, friction angle $(\phi$,$) of$ soil based on the maximum stress ratio and maximum deviator stress ........................... 40

Table 4-3 Calculation of cohesion (a), friction angle ( $\psi)$ and cohesion ( $\left.c^{\prime}\right)$, friction angle $(\phi$,$) of$

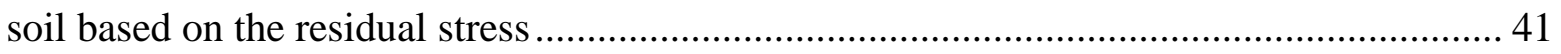

Table 4-4 Descriptive statistics of friction angle and effective friction angle on different failure

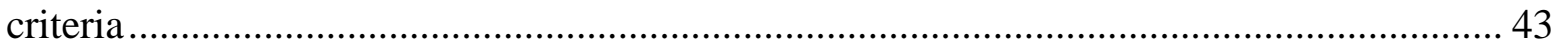

Table 4-5 Calculation of t-stat and other variables from regression analysis using Excel .......... 45

Table 4-6 The statistical description of different soil types................................................ 54

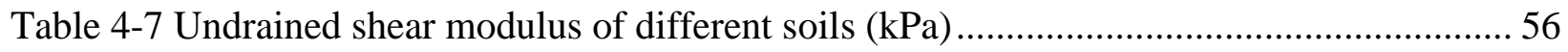

Table 4-8 Statistics evaluation of undrained shear modulus of different types of soils .............. 57

Table 4-9 Showing the descriptive statistics of the data for triaxial test ................................ 61 


\section{LIST OF FIGURES}

Figure 2-1 Geological map of the Toronto area (Sharpe 1980) …........................................ 7

Figure 2-2 Schematic map of ECLRT (http://www.thecrosstown.ca/the-project) ..................... 8

Figure 2-3 Grainsize distribution range of Silty Clay of Don Mills station .............................. 10

Figure 2-4 Grainsize distribution range of Silty Clay of Don Mills station ............................. 11

Figure 2-5 Grainsize distribution histogram of borehole number DM04 Don Mills station ........ 11

Figure 2-6 Grainsize distribution range of borehole number DM04 of Don Mills station........... 12

Figure 2-7 Grainsize distribution histogram of borehole number CH111 of Chaplin station ....... 13

Figure 2-8 Grainsize distribution range of borehole number CH111 of Chaplin Station............ 13

Figure 3-1 Schematic general set-up of a soil specimen inside a triaxial cell

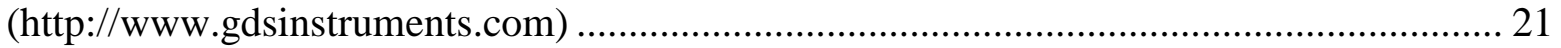

Figure 3-2 Specimen saturation by increasing back pressure (http://www.gdsinstruments.com) 22

Figure 3-3 B-check to confirm specimen saturation (http://www.gdsinstruments.com)............ 23

Figure 3-4 Consolidation stage (http://www.gdsinstruments.com) ..................................... 23

Figure 3-5 Specimen response of normally consolidated clay after shearing (left); Cohesive specimen post-shear showing failure plane (right). (from lab test) ................................ 24

Figure 3-6 Black Creek station pore pressure and deviator stress vs shear strain .................... 26

Figure 3-7 Black Creek station Mohr-Coulomb failure line .............................................. 26

Figure 3-8 The p'-q curve of Black Creek station with the depth of 23.11-23.75m ................. 28

Figure 3-9 The p'-q curve of Don Mills station with the depth of $28.42-29.82 \mathrm{~m} \ldots \ldots \ldots \ldots \ldots \ldots . . . . . . . .29$

Figure 3-10 The relationship between the failure criteria (Left) and Mohr-Coulomb failure envelop 30

Figure 3-11 Critical State Line (CSL) is draw by joining the locus of the points 32 
Figure 3-12 Critical State Line (CSL) is draw by joining the locus of the points of Black Creek

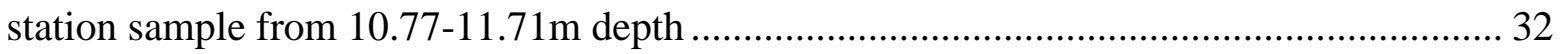

Figure 3-13 Different state of stresses with their characteristic values of Don Mills station at the

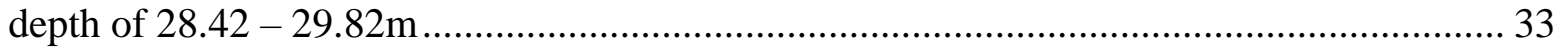

Figure 3-14 An Example of Secant modulus calculation of Black Creek Station 26m depth...... 34

Figure 4-1 Estimation of Preconsolidation pressure at a depth 27.71m of Don Mills Station using

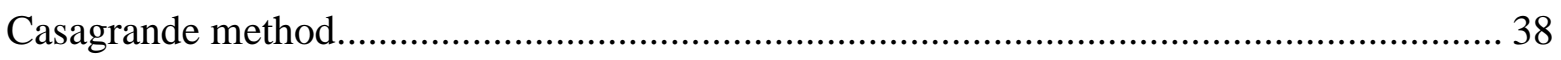

Figure 4-2 Stress Path (p'-q) curve of Don Mills station at depth of 28.42-29.82m ................. 38

Figure 4-3 Histogram plot of friction angle ( $\left.\phi^{\prime}\right)$ based on maximum deviator stress and the

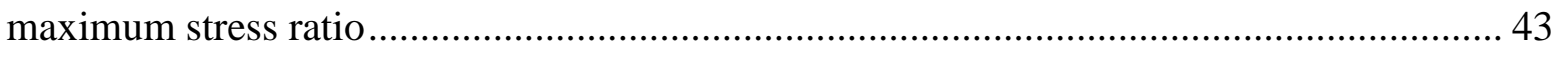

Figure 4-4 Relation between shear stress and normal effective stress at max. stress ratio.......... 44

Figure 4-5 Relation between shear stress and normal effective stress at max. deviator stress ..... 46

Figure 4-6 Relation between the shear stress and normal effective stress of Silty Clay ............. 47

Figure 4-7 Relation between the shear stress and normal effective stress of Clayey Silt ........... 48

Figure 4-8 Relation between the shear stress and normal effective stress of Clay ................... 49

Figure 4-9 Relation between the shear stress and normal effective stress of Clayey Silt Till..... 50

Figure 4-10 Relation between the shear stress and normal effective stress of Silty Clay Till ..... 51

Figure 4-11 Comparison of the shear stress and normal effective stress based on maximum deviator

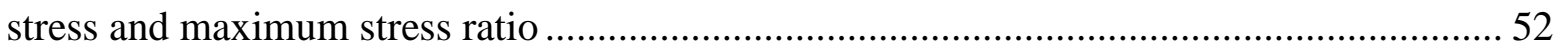

Figure 4-12 Soil type and friction angle relation ............................................................ 53

Figure 4-13 The triaxial test result showing different angle of failure in Allen station ( SPL, 2013)

Figure 4-14 The undrained shear modulus of different types of soil from GTA...................... 58

Figure 4-15 Relationship between OCR and the normalized deviator stress of GTA................ 59 
Figure 4-16 Various parameter of the soil and their range

Figure 4-17 Significance level for various parameter of the soil according to Shapiro-Wilk test 63 


\section{CHAPTER 1 INTRODUCTION}

\subsection{BACKGROUND}

In nature, soil is always heterogeneous due to the variations in grain size and composition, as a result it exhibits varying strength. The strength of the soil primarily depends on grain shape, size, orientation, composition, and water content. Usually, strength of the steel is measured in terms of tensile strength, strength of concrete is measured in terms of compressive strength, and strength of soil is measured in terms of shear strength. The shear strength of the soil is defined as the resistance to shearing that caused shear deformation. Shear strength is a crucial parameter in geotechnical engineering as it helps to obtain the bearing capacity of shallow and deep foundations, lateral pressure on retaining wall, pavement capacity, and slope stability analysis.

The greater Toronto area (GTA) is one of the most densely populated areas in Canada. The demand for public transportation is one of the major challenges for the city along with sewage and utilities managements due to fast urbanization. The other major challenge of the region is to manage the fluvial environments of the area which, in another words, is management and maintenance of existing natural areas from the degraded stream channels. To maintain natural beauty and serve for the city, the subway is the most suitable and reliable mode of transportation. Building a light rail transit (LRT) in a soil which had history of glacial deposits is challenging and lots of soil properties need to be considered. The glacial deposits found in Toronto and its surrounding are mostly till deposits. The borehole logs of this till indicates that they were originated from the ecological processes and are associated with the glaciation. Due to the nature of formation of glacier till, there are lots of inclusions or pockets of seams with heterogeneous materials such as sand, gravel, clay, or silt. In some cases, the till has cobbles (60 to $200 \mathrm{~mm}$ ) or boulders (over 200 $\mathrm{mm}$ ) and normal sampling equipment can't differentiate these materials. The heterogeneity is observed both laterally and vertically, however, in most of the cases more homogeneity is observed in the horizontal drilling and variation is observed in vertical drilling in terms of content of the soil particles.

The bedrock geology of the GTA is primarily sedimentary rocks at depth and the upper portion or the top layer of the area comprises of thick sediments deposited by glacier. The oldest formation 
of GTA comprises the sands, silt, and clays of the Scarborough Formation, which was deposited between 135,000 and 60,000 years ago, and lies on top of weathered shale bedrock (Eyles et al., 1998). The Sunnybrook Formation lies above the Scarborough Formation and dated about 50,000 years old. The layer above the Sunnybrook Formation is the Thorncliffe Formation and is comprised of layers of sands, silt, and clays, dated about 45,000 years old. The Northern Till lies above the Thorncliffe Formation and deposited between 20,000 and 45,000 years ago. Above the Northern Till layer lies the patches of the Halton Till/Mackinaw Interstadial Formations mostly composed of sand and gravel, deposited approximately 13,300 years ago (Eyles et al., 1998). The thickness of these formations varies in different areas and the order and compositions of layers of sand, silt and clay beds are different.

There were intensive geotechnical investigations carried out during the construction of Eglinton Crosstown Light Rail Transit (ECLRT). Different geotechnical properties of soil had been tested using different kinds of tests; such as grain size analysis, Atterberg Limit test, consolidation test, unconfined compressive strength test, triaxial test, standard penetration test, etc. To determine the shear strength of the soil, the triaxial test is most useful and this study will focus on the triaxial test of different soil types found in the study area. The shear strength of soil is very important to predict bearing capacity and behavior of soil upon loading. These data obtained from the test can be valuable for the future projects in GTA. In the planning phase if we know the shear strength of the soil then we can modify or rearrange support system or reevaluate the project's significance and longevity.

The geotechnical data obtained from the experiments are used to design the stability of structures. The information is not sufficient in quantity and not precise and accurate in every time due to the inhomogeneity of the natural materials and variable in scales ranging from microstructure to visible one. Due to lack of uniformity and information one should go through the parameterizing and model the physical world. The geotechnical investigation can be explained through the deterministic or probabilistic approaches. 


\subsection{RELIABILITY BASED GEOTECHNICAL DESIGN}

The reliability based design provides more consistent means of dealing with uncertainties, but it is not perfect solution. In many aspect of geotechnical engineering, the engineering judgement is necessary and the reliability analysis simply shows how uncertainties affect the performance of structure. The uncertainties encountered in geotechnical engineering design are mostly Epistemic uncertainty (i.e. lack of knowledge) rather than Aleatory uncertainty (i.e. pure randomness) (Beacher and Christian, 2003). The trend of using uncertainties analysis have been increasing in recent years in geotechnical community of North America (Goble 1999, DiMaggio et al. 1999, Green \& Becker 2001), and major agencies have shown their interest on it such as OHBDC3 (Ministry of Transportation Ontario 1992),

Nowadays the use of deterministic approach decreased to assess the variability of geotechnical parameters (i.e. quantifying, processing, and reporting) for design and characterization. For uncertainty based perspective the design code required to quantify not only the most suitable value but also the level of uncertainty and confidence to select such values. The deterministic approach involves single value comparison for design impact $(\mathrm{F})$ and design resistances $(\mathrm{R})$. On the other

hand the probabilistic procedures must account the distribution of all parameters and probability of occurrences $(\mathrm{pF})$.

Due to the origin of complex geological process the soil characteristics determination is complex and much more uncertainties than any other engineering materials like concrete or steel. So the soil characteristics values are still determined based on the experiences and only the mean values of the tests are used frequently. However the statistical method can be effective tools to minimize errors or soil risks while determining the soil properties.

The shear strength of the soil is most important parameter for the design of foundation as the bearing capacity of soil is depends on it. The shear strength is used to design embankments of dams, roads, excavations, pavements, levees, and for the stability analysis. The evaluation of shear strength of soil is necessary to design of earth's retaining structures on surface or underground structures. There is no such research have been done yet. 


\subsection{OBJECTIVE OF THE STUDY}

The scope of this research is to analyze shear strength properties of the soil in GTA using the triaxial test data along the ECLRT. The strength of the soil is most important to build any construction and the behavior of soil is changing from place to place due to inhomogeneity of the soil in the ground. The main objectives of this thesis are listed below:

1) Support reliability-based geotechnical design by conducting a statistical analysis of shear strength parameters of soils in the GTA. The reliability based design require soil characteristics and there are no such study till date on fine grained soil in GTA.

2) Calculate different properties of the soils such as axial strain, major effective stress, minor effective stress, pore pressure dissipation, deviator stress etc. from triaxial test data

3) There are many failure methods available to determine the shear strength parameter of soil but there is no comparison for soils in the GTA. This present study evaluates the impact of different failure methods on the shear strength parameter.

4) Conduct statistical analysis from triaxial test data to obtain geotechnical characteristics of fine grained soil in the GTA.

\subsection{METHODOLOGY}

A series of geotechnical tests must be carried out to build any infrastructure. The fine grained glacial tills were analyzed through the triaxial tests during the construction of ECLRT project, in different places. The triaxial tests were done in different stress conditions. Those test raw data were obtain from SPL Consultants.

The raw data obtained from the SPL consultant were used to calculate different parameters such as axial strain, major and minor effective stress, pore pressure dissipation, deviator stress, stress strain ratios, undrained shear strength etc. on excel. To determine the overconsolidation ratio, Oedometer analysis result is used to estimate preconsolidation pressure. 
The triaxial tests are used to determine the shear strength of the soil and can obtain the failure strength using different methods. Common methods to determine failure based on the maximum deviator stress and the maximum stress ratio. The maximum deviator stress can be obtained from the plot of deviator stress vs strain and the maximum stress ratio can be obtained after calculating the major and minor principal effective stresses.

\subsection{THESIS OUTLINE}

This dissertation is organized in five chapters, including introduction as first chapter. The second chapter describes the review of geology of the GTA along with the engineering properties of the soils. Chapter 3 reviews the shear strength of the soil along with the triaxial test and its significance. The theories of the shear strength and the calculation principals are also described in this chapter. Chapter 4 covers the statistical analysis of shear strength parameters. The triaxial test and the significance of the results that are derived from the analysis using different relationships of stress, strain, pore pressure deviator stress etc. Also the statistical analysis of different parameter are described in this chapter. Chapter 5 is the summary and conclusion of the dissertation and the final outcome of the thesis and also for the future research have been discussed. 


\section{CHAPTER 2 REVIEW OF GLACIAL DEPOSITS IN THE GTA}

\subsection{INTRODUCTION}

In the past time period there are different geological process undergone on the Earth's different places. Canada is one of the place where there was huge ice deposited on it. Due to temperature changes those ice sheets were melted and at the same time the glacial deposits occurred in the area. Due to variation in depositional processes, the soil parameters are also differ and it should be analyzed thoroughly. This chapter explains some of properties of the soil in the GTA, along the ECLRT alignment.

\subsection{REGIONAL GEOLOGY OF GTA}

According to Karrow (1967), almost all part of the Ontario had undergone three glacial periods and two interglacial periods. During these glacial and interglacial periods, several advances and retreats were observed (Karrow and White, 1998). Due to these characteristics in the past the subsurface deposits have significant changes within small distances. The glacial tills that are found these days are particularly deposited in late Wisconsian Periods and represented by different groups such as Sunnybrook, Seminary, Meadowcliffe, Newmarket and Halton Tills (Sharpe et al., 1999). By classification, the till deposits can be divided into cohesive with low plasticity and cohesionless glacial tills (Manzari et al., 2014). The general geological map of the GTA is shown in Figure 2-1.

In GTA, the ice was more than one kilometer thick, and it deposited a layer of till during a glacial retreat. The giant ice-plow scooped more material out of several big valleys forming new lakes and making existing lakes more elliptical. The glacial tills are highly variable laterally and vertically due to its depositional nature, and soil composition. The soil contains all grain sizes from as course as the boulder size to as fine as clay particles. As the glacial till was covered by several hundreds of meter thick ice, the soil was over consolidated in most cases and shows non-linear stress-strain characteristics (Baker et al. 1998). Studies show that the cobbles and boulders are more common in these deposits. 


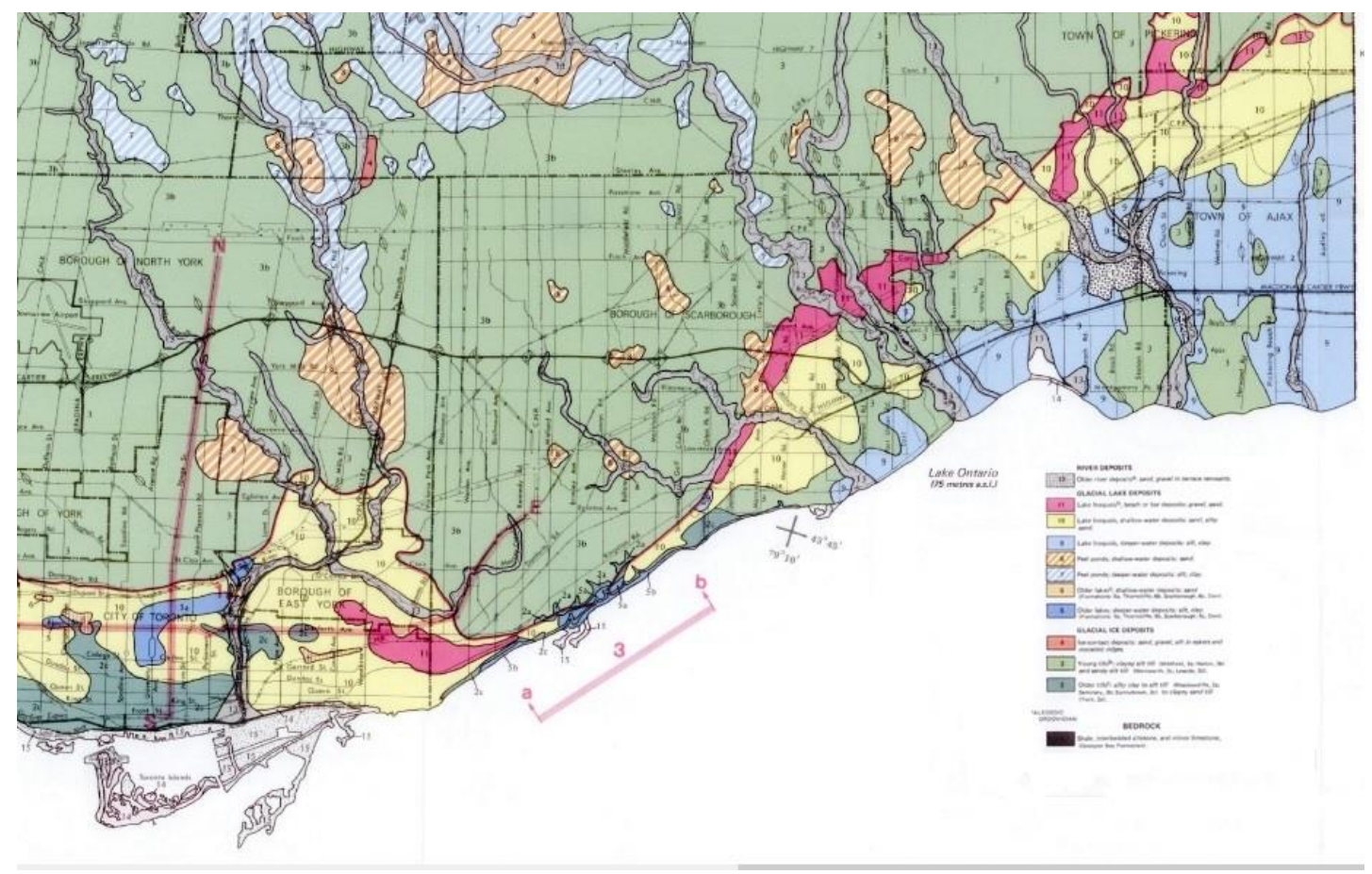

Figure 2-1 Geological map of the Toronto area (Sharpe 1980)

\subsection{ENGINEERING BACKGROUND OF THE STUDY}

The Eglinton Crosstown Light Rail Transit (ECLRT) is approximately $33 \mathrm{~km}$ in length and passes through Toronto downtown, near Lake Ontario, see the schematic map of ECLRT in Toronto (Figure 2-2) (ttc.ca). During the investigation for this ECLRT different in-situ and laboratory tests were performed. The in-situ tests include, standard penetration tests (SPT), Vane shear test, seismic test, hydraulic conductivity and pressure meter tests (PMT) whereas the laboratory test includes moisture content, grain size, hydrometer analysis, density, Atterberg limit test, consolidation test, point load test, and triaxial tests (drained and undrained). Although there are several tests performed only few are done in all stations, like grain size analysis, moisture content, Atterberg limit test. According to Toronto Transit Commission (TTC), Geotechnical Standard (TTC 2014), the soil is classified as glacial till and further sub-classified as cohesive glacial till with low plasticity and cohesionless glacial till. The glacial till with low plasticity is further classified into two classes a) Silty Clay Till, b) Clayey Silt, whereas the glacial till of cohesionless soil is further divided into two classes c) Sandy Silt Till, d) Silty Sand Till. There is a variation in soil types in each borehole due to the nature of glacial advancement and retreat. 
During the drilling of borehole, the encountered glacial till generally consists of coarse grained cohesionless deposits of silt, silty sand, sand and gravelly sand interbedded with the fine grained silty clay and clayey silt. The relative density of cohesionless tills are very loose to dense, but the prominent soils are very dense and the SPT-N value ranges from 1 to more than 50 blows within $300 \mathrm{~mm}$ penetration.

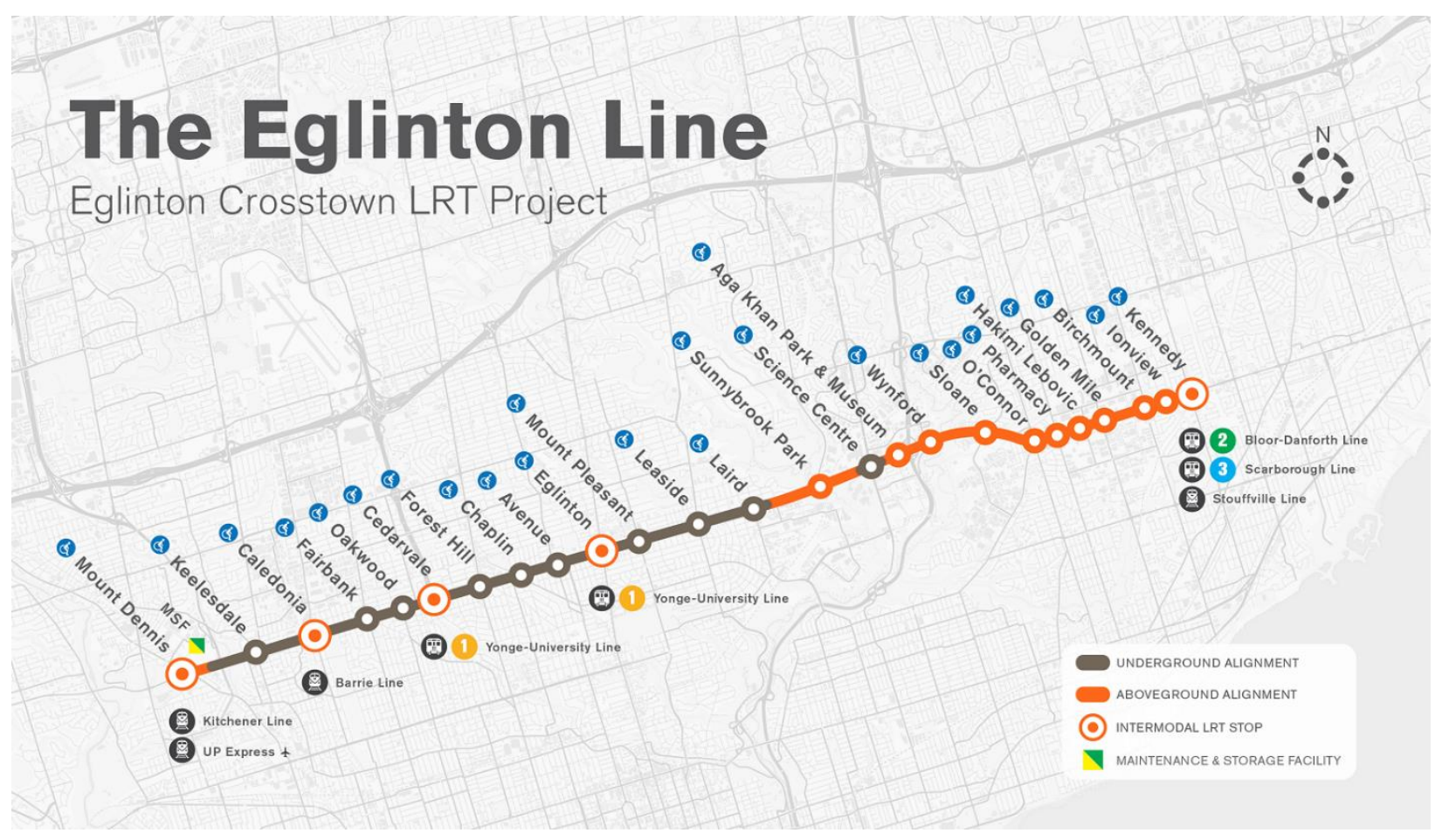

Figure 2-2 Schematic map of ECLRT (http://www.thecrosstown.calthe-project)

\subsection{ENGINEERING PROPERTIES OF GLACIAL TILLS}

\subsubsection{Grain Size Distribution}

The glacial and interglacial deposits can be distinguished by observing soil texture. The grain size analyses of glacial till deposits are generally well-graded, containing different percentages of gravel size to silt and clay particles. Sometimes the glacial till also contains cobbles and boulder sized particles. The glacial till can be divided into cohesionless glacial till (Silt, Sandy Silt, Silty Sand, Sand and Gravelly Sand) and cohesive glacial till (Silty Clay Till and Clayey Silt Till) based on the consistency of the soil. 
The grain size analysis of glacial till has great variations in sizes and composition, ranging from up to $14 \%$ gravel, $2-90 \%$ sand, $58-86 \%$ silt to more than $40 \%$ clay particles. The moisture content in soil primarily depends on the grain size, composition, and the phreatic level in particular sample location. It is observed that increasing grain size from silt to sand or gravel corresponds to increasing SPT-N values.

\section{b) Silty Clay Till (CL) and Clayey Silt Till (CL-ML)}

The sandy silt till and silty sand till consists of 2-5\% gravel, more than $44 \%$ silt and sometimes 5$20 \%$ clay particles. The fine grain cohesive soil consists of silty clay (CL), and clayey silt (CLML) in varying proportions and the moisture content ranges from 10-35\%. The grain size consists of nearly $20 \%$ sand and more than $40 \%$ of clay particles. The liquid limit and plastic limit varies from $24-55 \%$ and $15-30 \%$, respectively. The plasticity index also varies and can be classified into (CL-ML) based on TTC (TTC, 2004). There is a wide range of grain size distributions and Atterberg limits values found in cohesive tills in the GTA.

\section{c) Boulders and Cobbles}

The boulders and cobbles are common in the soil of GTA. The percentage and size of boulders and cobbles vary from location to location, hence difficult to quantify solely on the basis of borehole drilling data. However, the other parameter such as SPT-N values and sediments obtained by auger drilling indicates the presence of rock fragments in the glacial till deposition of the GTA. The size and percentage of boulders and cobbles within the glacial tills are difficult to quantify through borehole drilling.

TTC has adopted ASTM (2011) definition to define boulder size fragments. Two parameters are used to describe the boulder frequency, boulder volume ratio (BVR) and the boulder number ratio (BNR). The boulder volume ratio is defined as the ratio of the cumulative volume of all boulders to the total excavated volume of ground, whereas the boulder number ratio is defined as the number of boulder per cubic meters of cumulative boulder volume encountered (Boone et al., 1998). The value of BVR and BNR are site specific and never the same, and primarily depends on depositional 
behavior of glacial till. The maximum dimension of boulder reported was $3 \mathrm{~m}$. The boulder volume ratio in interglacial deposits and glacial tills are $0.12 \%$ and $0.17 \%$ respectively, recommended for the TTC project (Boone and Shirlaw, 1996).

The grainsize distribution is different in different places. Most of the soil are sandy soil although clay particles are abundant. The grainsize distribution of different areas are shown in Figures 2-3 to $2-8$.

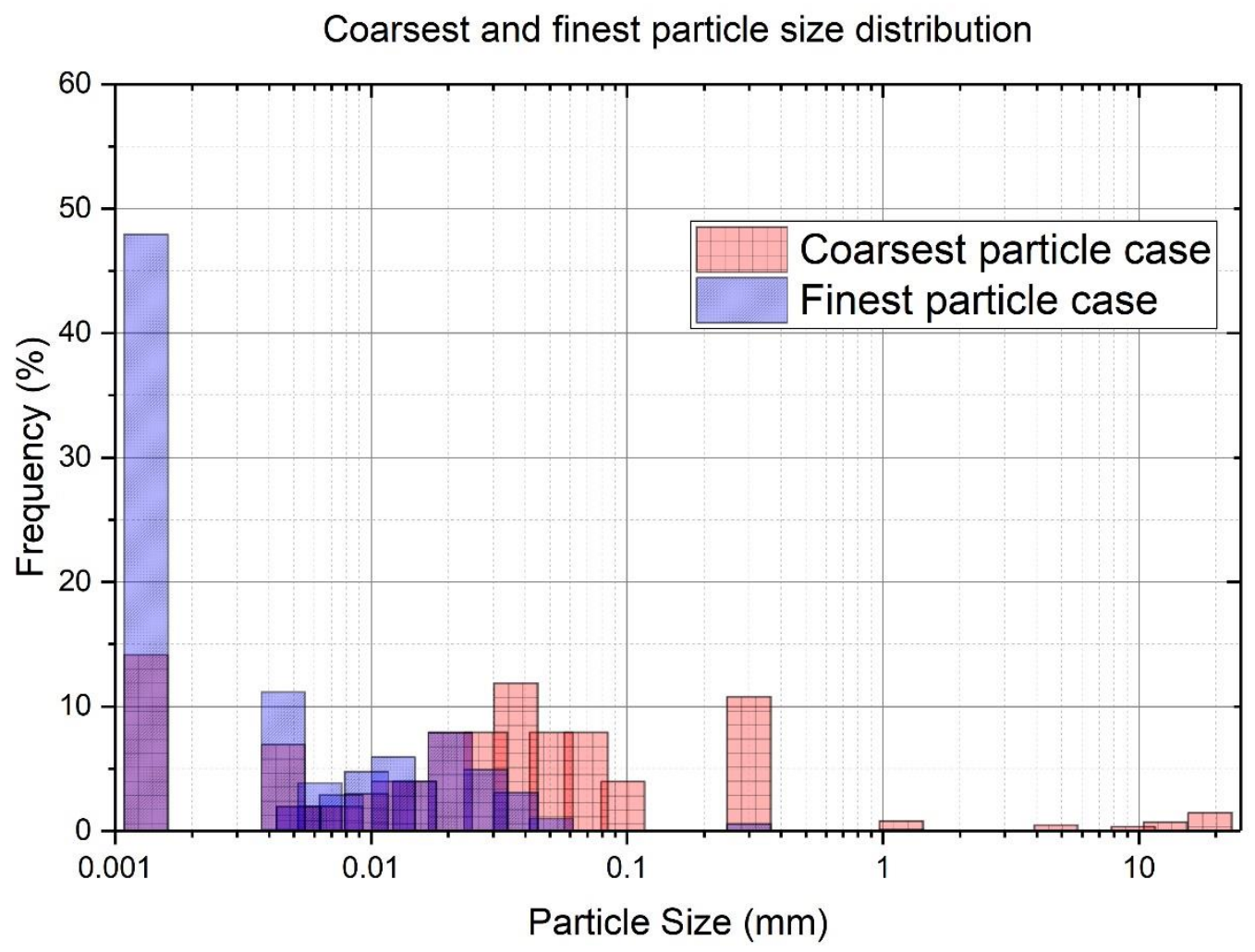

Figure 2-3 Grainsize distribution range of Silty Clay of Don Mills station

The figure $2-3$ shows that more than $45 \%$ of soil belong to very fine grained soil and all soil have their diameter below $0.1 \mathrm{~mm}$., which means the soil have almost all fine grained. On the other hand, the coarsest soil particle ranges all types of soil fine to course but the coarse grained soil are very low in proportion (Figure 2-3 and 2-4). 


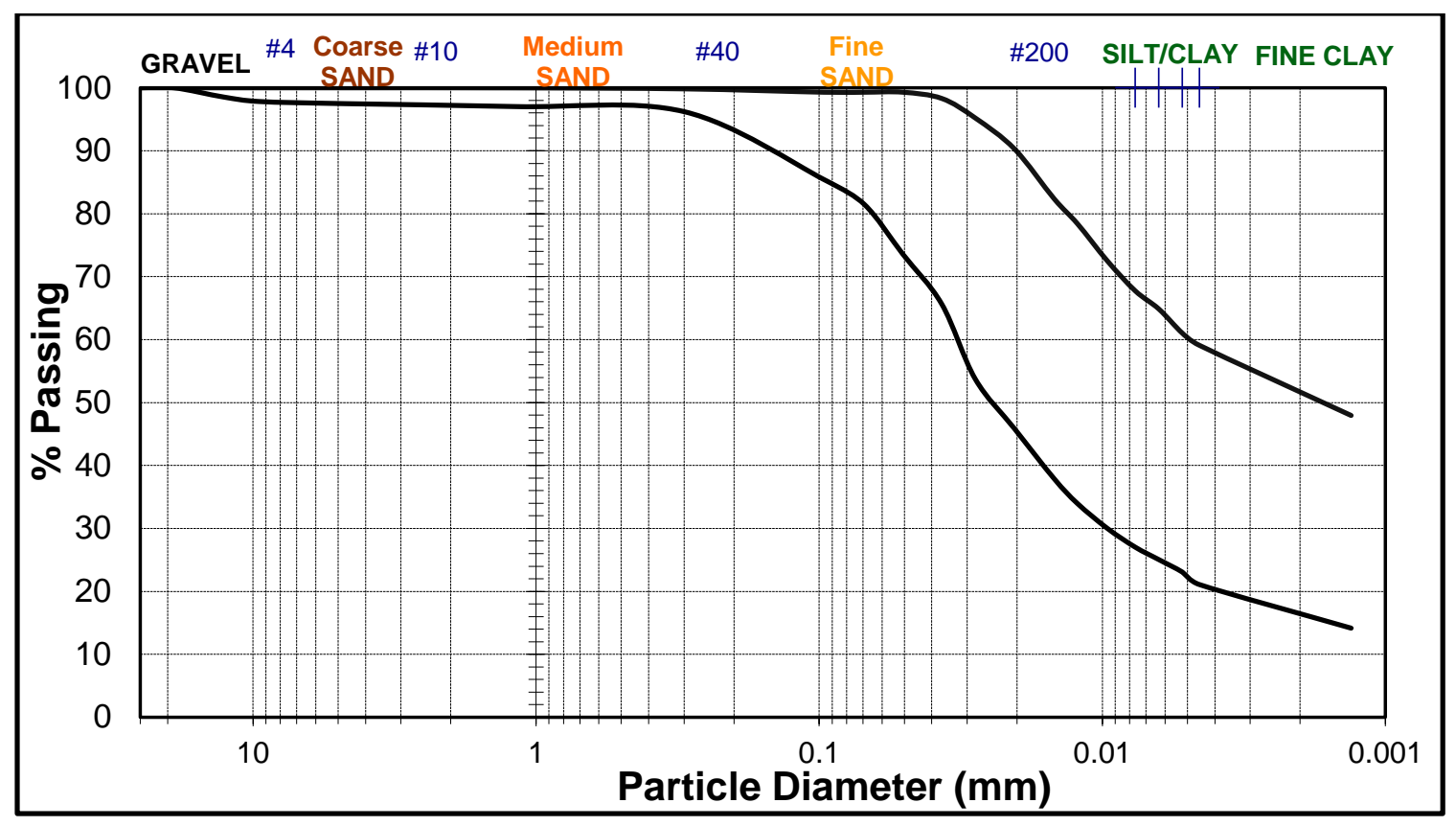

Figure 2-4 Grainsize distribution range of Silty Clay of Don Mills station

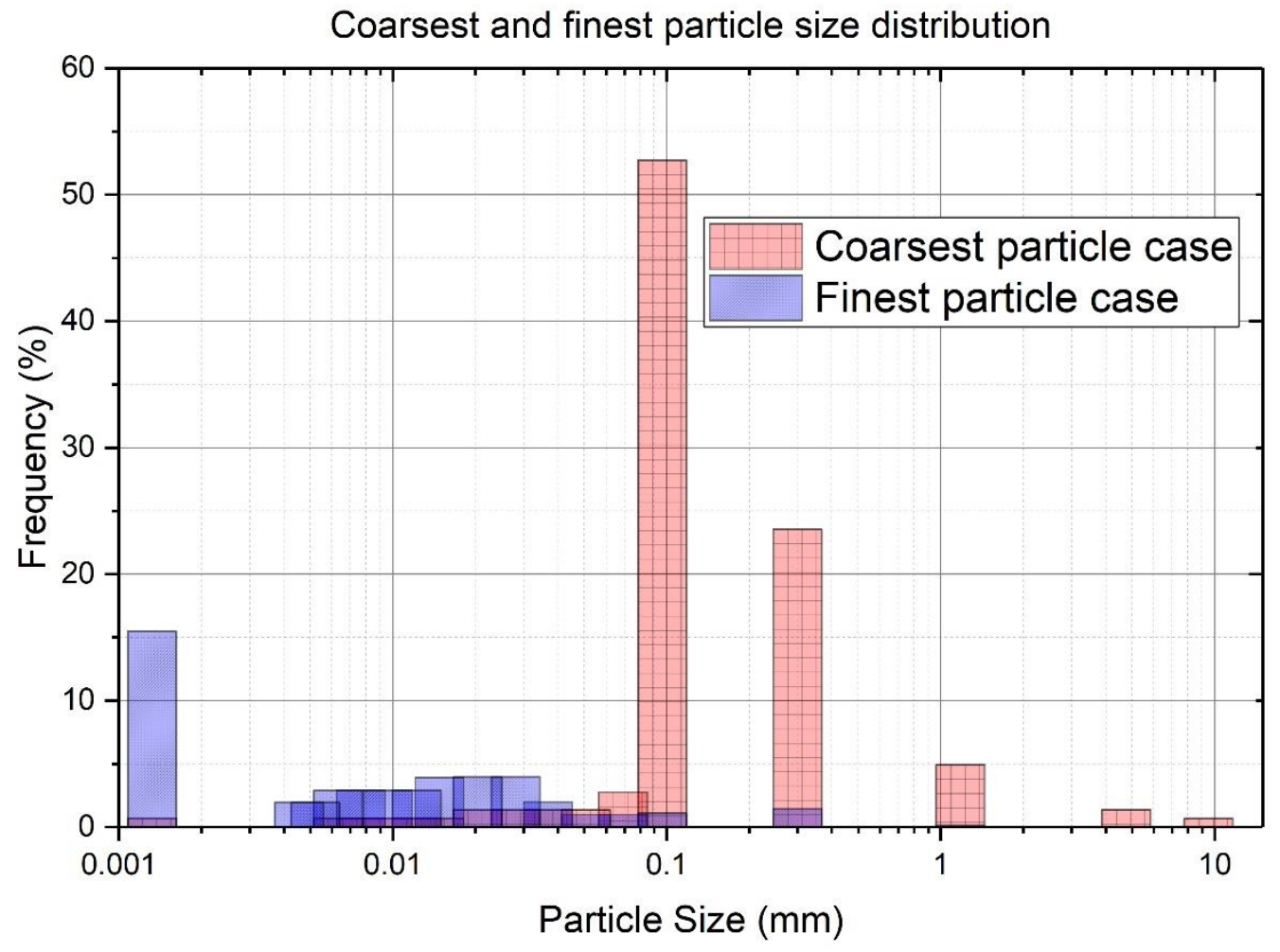

Figure 2-5 Grainsize distribution histogram of borehole number DM04 Don Mills station 


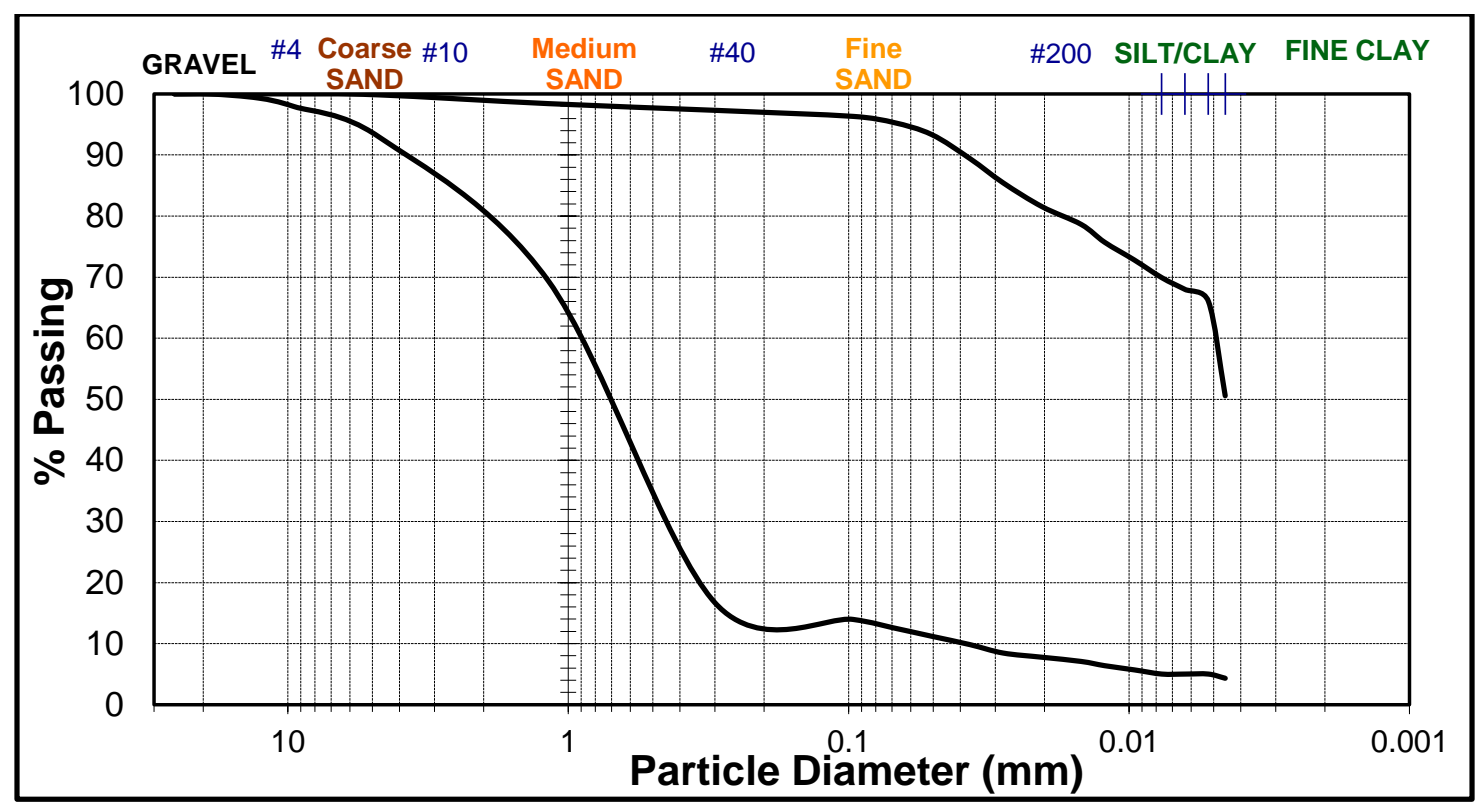

Figure 2-6 Grainsize distribution range of borehole number DM04 of Don Mills station

The soil from the borehole number DM04 of Don Mills have also wide variation in the particle size distribution. It is found that the finest particle size distribution contains almost all particle having diameter less than $0.1 \mathrm{~mm}$ and the coarsest particle size distribution is more than $50 \%$ of particle size on $0.1 \mathrm{~mm}$ and some are lies higher diameter size.

The figure 2-7 and 2-8 represents the soil grain distribution of Chaplin station of borehole number $\mathrm{CH} 111$. The finest particle size grains lies almost all having diameter size $0.1 \mathrm{~mm}$. and more than $50 \%$ of soil have their particle diameter about $0.001 \mathrm{~mm}$. On the other hand the coarsest particle size contain more than $50 \%$ of grains sizes $0.3 \mathrm{~mm}$ to $0.4 \mathrm{~mm}$ in diameter. Around $4-6 \%$ of the soils have their grain size more than $1 \mathrm{~cm}$. 
Coarsest and finest particle size distribution

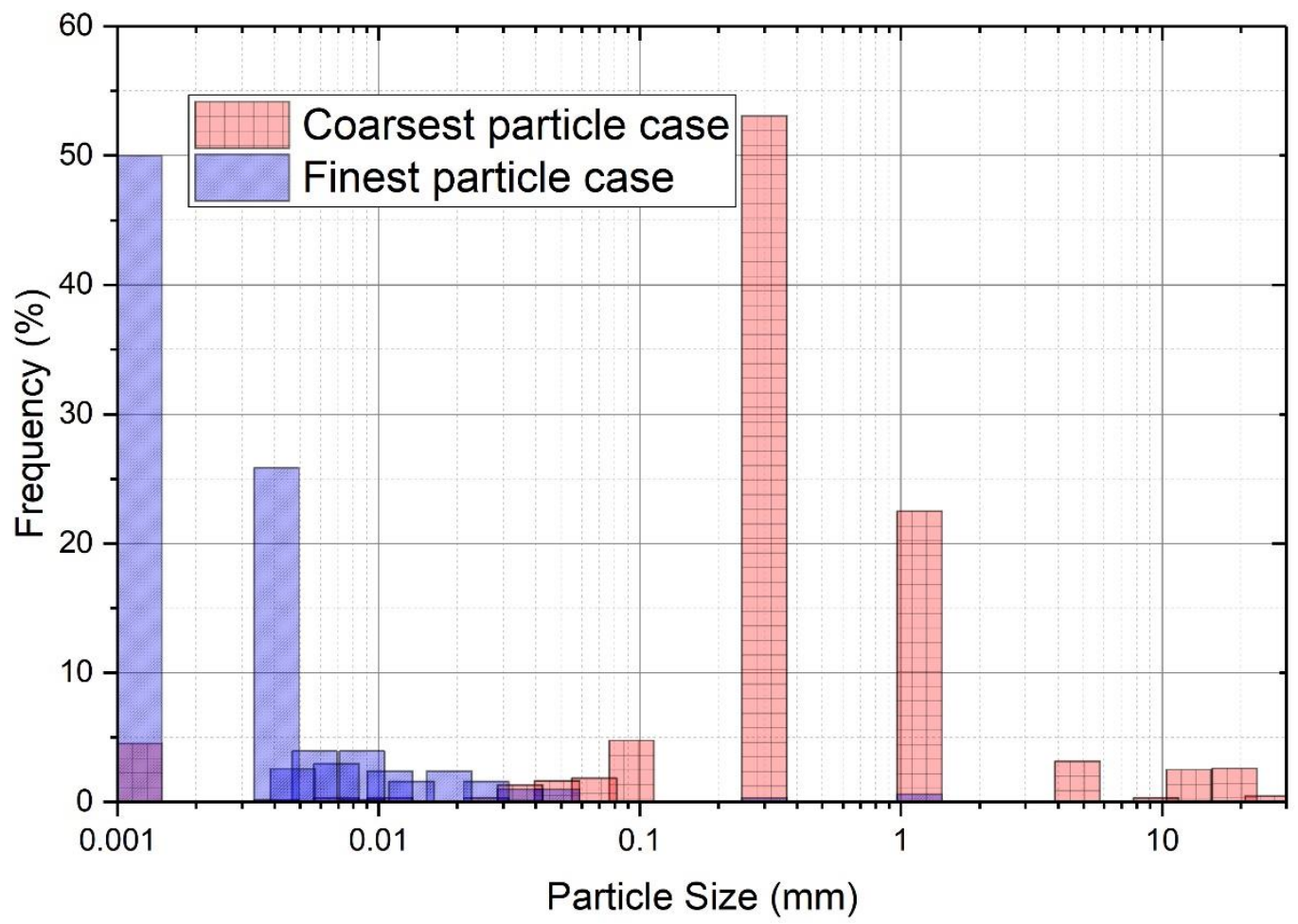

Figure 2-7 Grainsize distribution histogram of borehole number CH11 lof Chaplin station

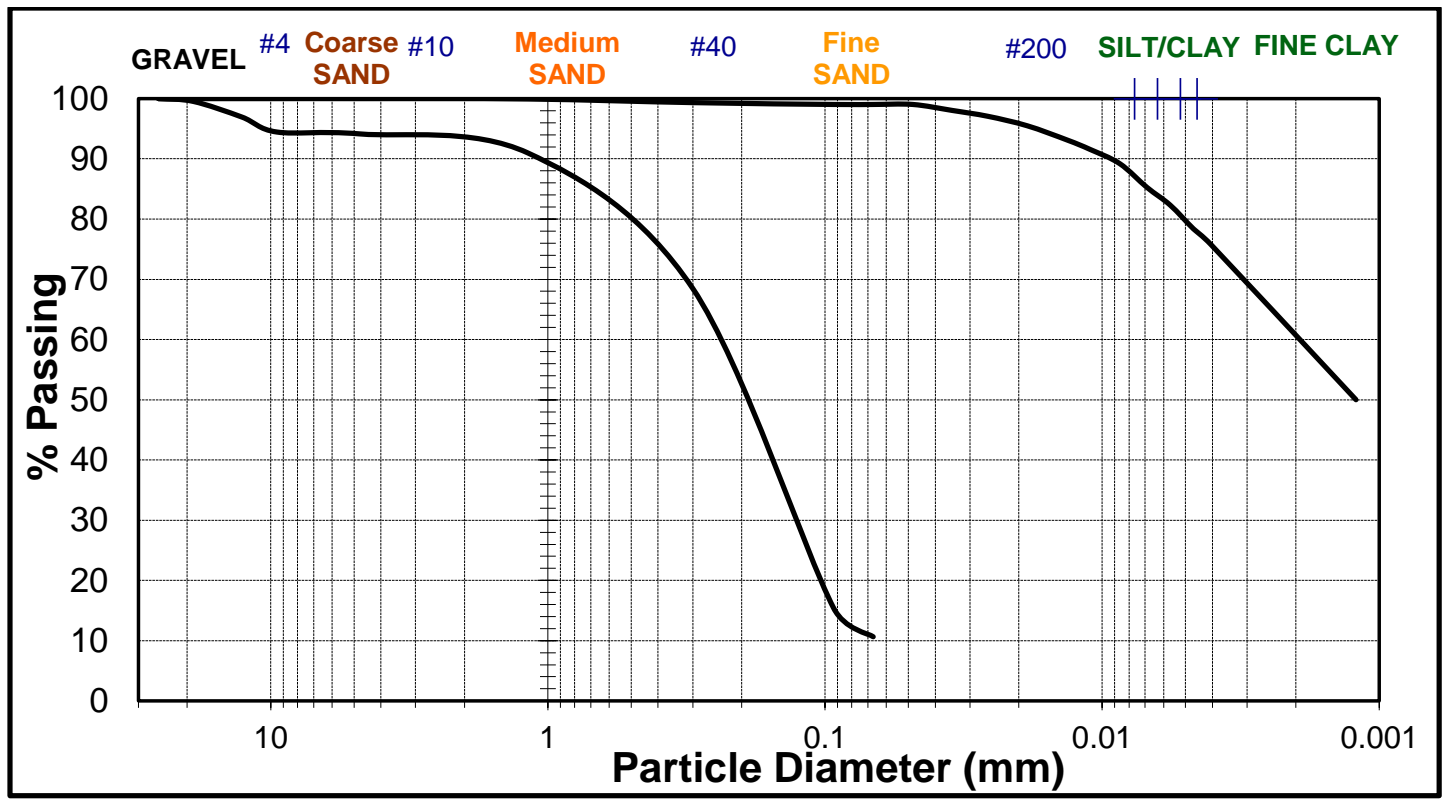

Figure 2-8 Grainsize distribution range of borehole number CH111 of Chaplin Station 


\subsubsection{Water Content and Unit Weight}

The water content (w) of silty clay till ranges from $7 \%$ to exceeding $40 \%$ in some cases and the water content of clayey silt till is similar to silty clay till, ranging from $6 \%$ to nearly $33 \%$. The water content of sandy silt till to silty sand till is generally lower than that of the cohesive silty clay till to clayey silt till. The statistical distributions of water content of the glacial tills indicates that more than $50 \%$ of the cohesive till samples have the water content ranging from $10 \%$ to $18 \%$, whereas more than $50 \%$ of the cohesionless till samples have the water content ranging from $6 \%$ to $10 \%$.

The unit weight $(\gamma)$ obtained from different samples of the silty clay till ranged from 20.0 to 23.9 $\mathrm{kN} / \mathrm{m}^{3}$ with an average value of $22.6 \mathrm{kN} / \mathrm{m}^{3}$; the unit weight $(\gamma)$ of clayey silt till was similar to that of the silty clay till and ranged from 19.9 to $24.0 \mathrm{kN} / \mathrm{m}^{3}$ with an average value of $22.6 \mathrm{kN} / \mathrm{m}^{3}$. The unit weight $(\gamma)$ of the cohesive tills are generally lower than that of the cohesionless tills. The unit weight measurement is more realistic when the soil has some cohesion or cementation. The unit weight of the cohesive soil decreases with the increase in water content. Both of soil, clayey silt till and silty clay till shows similar results in terms of water content and unit weight. The unit weight of the cohesive tills can be estimated from the water content using the following equation (Cao et al., 2015):

$$
\gamma\left(k N / m^{2}\right)=24.2-0.13 w \pm 1.5
$$

where $w$ is the water content

The unit weight of the silty clay till and clayey silt till can also be estimated from with the SPT N values. It is obvious that the increases in SPT-N value increases when unit weight of the soil increases. For a higher SPT-N value, the unit weight is generally greater than $22 \mathrm{kN} / \mathrm{m}^{3}$, whereas for a lower SPT-N value, the unit weight ranged from 19.9 to $21.6 \mathrm{kN} / \mathrm{m}^{3}$, as reported by SPL Consultant on Don Mills Station (SPL, 2013). 


\subsubsection{Consolidation Parameters}

The consolidation test can be used to evaluate how much settlement can occur if the load is applied. The test conducted in cohesive till samples indicated that they are mostly overconsolidated. The compression index $\left(\mathrm{C}_{\mathrm{c}}\right)$ of the soil ranges from 0.037 to 0.121 and the recompression index $\left(\mathrm{C}_{\mathrm{r}}\right)$ ranges from $0.008-0.016$. The coefficient of consolidation $\left(\mathrm{C}_{\mathrm{v}}\right)$ ranges from $2 \times 10^{-2}$ to $5 \times 10^{-4} \mathrm{~cm}^{2} / \mathrm{s}$ (Laifa Cao et. al 2015). The consolidation test gives us the pre-consolidation pressure which are useful to determine the over consolidation ratio of the soil. The characteristics of glacial tills are so complex due to glacial advance and retreat. The consolidation history is one of the most important factors to determine the mechanical properties of soil for understanding the stress history.

The consolidation parameters are used for the calculation of overconsolidation ratio. There are only a few consolidation tests performed in the soil. The Casagrande method uses consolidation test data to determine preconsolidation pressure. During the triaxial test, some tests were run with confining pressure lower than that of preconsolidation pressure. Preconsoildation pressure is used to calculate overconsolidation ratio.

\subsection{SUMMARY}

This chapter introduced the general properties of the glacial deposits of GTA. The grain sizes found in the area and the range of grains from clay to boulders. Most of the area were covered by the fine grained soil and their liquid limits are high in variation. Whereas the unit weight of the soil are similar. It is most important to know the geotechnical properties of the soil before the construction of any infra-structures. The geotechnical properties of soil primarily depends on the soil composition, soil's compressibility and moisture content. The next chapter describes the shear strength of the soil found in the GTA during the construction of ECLRT. 


\section{CHAPTER 3 SHEAR STRENGTH OF SOIL AND TRIAXIAL TEST}

\subsection{INTRODUCTION}

This chapter introduces the factors affecting shear strength of the soil and the procedure of triaxial test along with the relation within various parameters. First the shear strength of the soil, its properties and the calculation along with the effect of pore water pressure will be discussed. Next the triaxial test procedure will be discussed. Finally, the triaxial test results will be discussed along with the calculation procedures for different criteria and soil strength parameters.

\subsection{SHEAR STRENGTH OF SOIL}

The soil has complex behavior due to presence of pore water pressure, so to determine the strength of the soil shear strength is measured. The individual soil particles can slide or roll relative to each other generating a shear displacement. The shear strength is the maximum shear stress applied to a soil mass before it failed along the shearing plane. To determine the bearing capacity of foundation, we need to know the shear strength of soil because. Fredlund et al. (1978) proposed an equation using two independent stress state variables; net normal stress ( $\left.\sigma_{u a}\right)$ and matric suction $\left(\mathrm{U}_{\mathrm{a}}-\mathrm{U}_{\mathrm{w}}\right)$. And the equation is as follows;

$T_{f f}=C^{\prime}+\left(\sigma_{f}-u_{a}\right) f \times \tan \emptyset^{\prime}+\left(U_{a}-U_{w}\right) f \times \tan \emptyset^{b}$

where $T_{\mathrm{ff}}$ is shear stress on the failure plane at failure;

$\mathrm{C}^{\prime}$ is intercept of the Mohr-Coulomb failure envelope on the shear stress axis;

$\left(\sigma_{\mathrm{f}}-\mathrm{u}_{\mathrm{a}}\right)_{\mathrm{f}}$ is net normal stress on the failure plane at failure;

$\sigma_{\mathrm{ff}}$ is total normal stress on the failure plane at failure;

$\mathrm{u}_{\mathrm{af}}$ is pore-air pressure at failure;

$\phi '$ is angle of internal friction associated with the net normal stress state variable;

$\left(\sigma_{\mathrm{f}}-\mathrm{u}_{\mathrm{a}}\right)_{\mathrm{f}} ;\left(\mathrm{u}_{\mathrm{a}}-\mathrm{u}_{\mathrm{w}}\right)_{\mathrm{f}}$ is matric suction at failure;

$\mathrm{u}_{\mathrm{wf}}$ is pore water pressure at failure;

$\phi^{\mathrm{b}}=$ angle indicating the rate of change in shear strength relative to changes in matric suction 
The triaxial shear test are best described using Mohr-Columb failure criteria. The stress path and Mohr circle is the best representation of triaxial shear condition. As defined by Skempton and Bishop (1954), the shear strength is as the maximum shear stress that the soil could tolerate.

Shear resistance have three different components cohesion, friction, and dilatency. The mobilization between two adjacent particles that interact or stick to each other without any external pressure is the cohesion. The linkage between adjacent particles increases the force within the particles. The friction is the resistance between particles when they move relatively to each other. The dilatency is geometric interference of particles that gives higher shear resistance due to increase in volume. At this moment the pore pressure will be negative.

\subsubsection{Undrained Shear Strength}

Terzaghi et al., (1996) conducted different laboratory tests on saturated clay. For the study of undrained shear strength of the clay Terzaghi used unconsolidated undrained and consolidated undrained tests. The test on saturated clay gave very small (almost zero) angle of shear resistance when there was no change in water content. Skempton (1948b) performed an unconsolidated undrained test at constant hydrostatic pressure $\left(\sigma_{3}\right)$ and increasing axial pressure until failure. There was not any change in water content. During his experiment it was found that the compressive strength of saturated clay $\left(\sigma_{1}-\sigma_{3}\right)$ was unchanged. When clay behaves as purely cohesive material and shearing resistance angle $(\phi)$ is equal zero. However, Skempton (1948b) concluded that $\phi=0$ can't be applied to partially saturated soil. The undrained shear strength $\left(\mathrm{S}_{\mathrm{u}}\right)$ can be calculated using following formula:

$S_{u}=\frac{1}{2}\left(\sigma_{1}-\sigma_{3}\right) f$

\subsubsection{The Principle of Effective Stress}

The effective stress controls the deformation behavior of saturated soil (Terzaghi, 1920) and the effective stress is defined in terms of the total stress and pore water pressure. 
$\sigma^{\prime}=\sigma-u$

where $\sigma$ is total stress, $\sigma^{\prime}$ is effective stress and $u$ is pore water pressure.

The saturated soil has soil particles and water in all voids. When the total stress is applied on it, it causes an increase in pore pressure. This increased pore pressure starts to dissipate from the soil transferring stresses to soil particle which is called effective stress.

\subsection{LABORATORY AND FIELD TESTING TO DETERMINE SHEAR STRENGTH PARAMETERS}

To measure the undrained shear strength of the soil, there are many laboratory and field tests in use. The field test includes the cone penetration test (CPT) and the field vane shear test. The laboratory method used to measure the undrained shear strength includes; unconfined compression strength (UCS) test, direct shear test, unconsolidated undrained (UU) test, triaxial test, and fall cone test. Different test procedures laboratory or field may give some variation in the results of undrained shear strengths.

\subsubsection{Triaxial Test}

The triaxial test first introduced by Casagrande is more complicated and versatile than the direct shear tests. In triaxial test, we can control the applied stress and confining stress. The test can be performed in either drained or undrained condition. The common triaxial tests are consolidated undrained (CU) and consolidated drained (CD) test. For both of these tests, the sample is consolidated under isotropic condition (can be anisotropic also) and then load is applied allowing the shear failure. For the CU test the soil sample is sheared in undrained conditions with or without excess pore pressure whereas in the CD test, the sample is sheared in drained condition i.e.

allowing the dissipation of pore water pressure. During the triaxial test, the soil specimen is enclosed by a flexible membrane, which prevents the induction or expulsion of pore water from the soil. The back pressure is applied to soil specimen to make sure the soil is saturated. Back pressure increases the cell pressure and pore pressure at the same time and allow equalization at 
each increment. The B-parameter is measured before applying additional increment. The B coefficient can be calculated as

$B=\Delta u / \Delta \sigma_{3}$

where $\Delta \mathrm{u}$ is change in pore pressure and $\Delta \sigma_{3}$ is change in cell pressure.

In this condition, the soil specimen is under confining stress exerted by a fluid. The fluid pressure represents two minor principal stresses whereas both the fluid pressure and axial force gives the vertical stress. In general the axial stress is the major principal stress. The stress is transmitted to the soil through rigid porous plates which used to perform either drained or undrained conditions

during the loading phase. The measurement of axial deformation is done directly by monitoring the movement of the end plate or piston.

\subsubsection{Consolidated Undrained Test}

The consolidated undrained test is one type of triaxial tests where the soil specimen is isotopically consolidated under hydrostatic pressure before increasing major principal stress without allowing drainage from the specimen to let the shearing happen. The measurement of pore pressure is not mandatory in this test. If the pore pressure is measured, then the result can be expressed in terms of both total and effective stresses. There is a standard procedure for CU test using the effective pressure (Mayne 1985).

As soil is anisotropic, the major and minor principal stresses are not equal due to the ground condition, and can be calculated using minor principle stress over major principle stresses \{Lateral earth pressure $\left.(\mathrm{K})=\sigma_{3} / \sigma_{1}\right\}$. The overconsolidated clay also exhibit anisotropic condition where $\mathrm{K}$ $>1$ and natural soft clay exhibit $\mathrm{K}<1$. In order to evaluate the anisotropic nature of soil, a special procedure of an anisotropic consolidation can be used to replace the standard isotropic consolidation mentioned above to simulate better the field condition. 


\subsection{TRIAXIAL TEST PROCEDURES}

The triaxial test specimen must be cylindrical with a standard sample height vs diameter ratio of 2:1. The soil specimen diameter ranges from 38 to $100 \mathrm{~mm}$ and covered by the rubber membrane. This rubber membrane prevents water drainage from soil sample and water inclusion from the confining chamber to the soil sample. The prepared soil specimen is placed into the triaxial test machine, and proceeds for the saturation, consolidation, and shearing stages, which allows us to see the soil response under approximately in-situ conditions. After consolidation, the soil will go to shearing stage by applying load axially. The general triaxial specimen setup is shown in Figure 3-1. Primarily there are three different ways we can conduct the triaxial tests in laboratory. They are as follows:

- Unconsolidated Undrained test (UU)

- Consolidated Undrained test (CU)

- Consolidated Drained test (CD)

The triaxial tests carried out for ECLRT were mostly CU triaxial test. This test is the most common procedure as it allows to determine the strength parameters (i.e. $\phi^{\prime}$ and $c^{\prime}$ ) based on the effective stresses which permits faster rate of shearing in compared with the CD test. The recording of excess pore pressure change within the specimen during shearing helps to get strength parameters. 


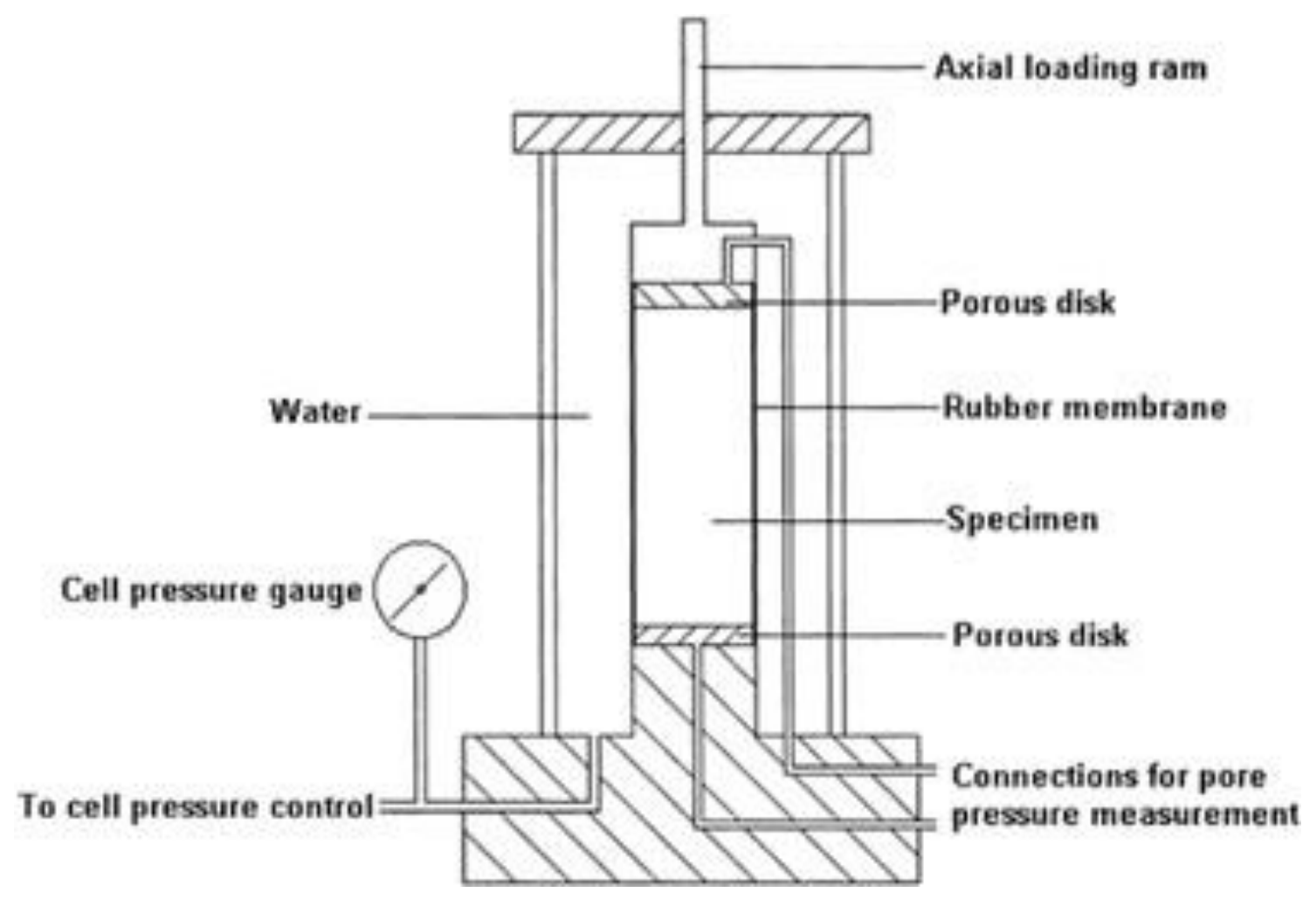

Figure 3-1 Schematic general set-up of a soil specimen inside a triaxial cell (http://www.gdsinstruments.com)

\subsubsection{General Triaxial Test Procedure}

The general triaxial test procedure typically consists of four different stages: a) specimen and system preparation, b) saturation, c) consolidation, and d) shearing.

\section{a) Specimen \& System Preparation}

The soil sample is prepared on specified dimensions before placing it into the triaxial cell. There are different preparation methods for different types of soil samples. For the cohesive soil specimen, the preparation starts with trimming undisturbed soil that extruded from Shelby tubes or cut from the block samples. For the granular soil sample, it is required to prepare from the pedestal using a split part of mould. A membrane suction stretcher is use to place the rubber membrane around the soil sample. This membrane prevents the water inclusion or dissemination from the soil sample. This process is followed by the placement of specimen into the triaxial cell 
and assemblages of other components. Then cell is filled with water pressure and volume controllers connected and parameters are set as required.

\section{b) Saturation}

The saturation is the process of filling out all pore spaces within the test sample and de-airing of the drainage lines. To reach de-aired condition partial vacuum is applied to allow air to pass out and to draw water into the transducer and drainage line, then cell and back pressures are a linearly increased. The figure below (Figure 3-2) shows that the constant effective stress is maintained during the process of de-airing to make sure the increase in effective stress is less than the required shearing. If the increase in effective stress is above the shearing the sample leads to overconsolidation. For the full saturation following two steps are taken:

- Use of de-aired water to fill specimen voids.

- Increase of back pressure to force air into solution (as shown in Figure 3-2).

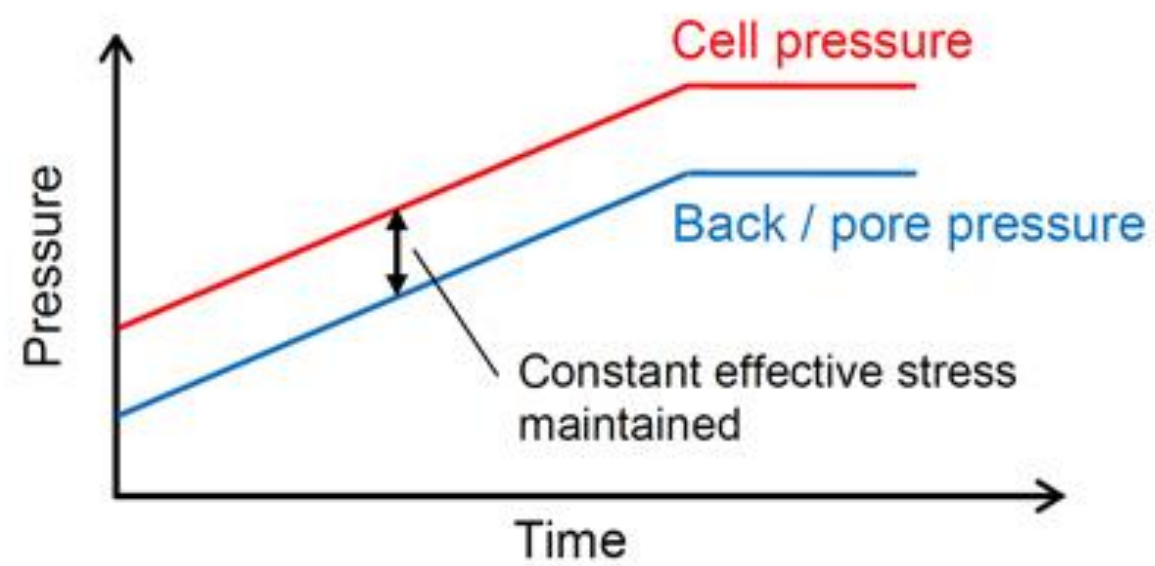

Figure 3-2 Specimen saturation by increasing back pressure (http://www.gdsinstruments.com)

Before moving to the consolidation stage degree of saturation is tested to determine the Skempton's B-value. During this procedure, also known as B-check, specimen drainage is closed and cell pressure is raised approximately $50 \mathrm{kPa}$ (Figure $3-3$ ). The $\mathrm{B}$-value $>0.95$ is used to confirm saturation of the specimen, but this B-value depends on the soil. For normally consolidated soil, B $\approx 1.00$ is at full saturation while it is approximately 0.91 for stiff clay at fully saturated condition. 


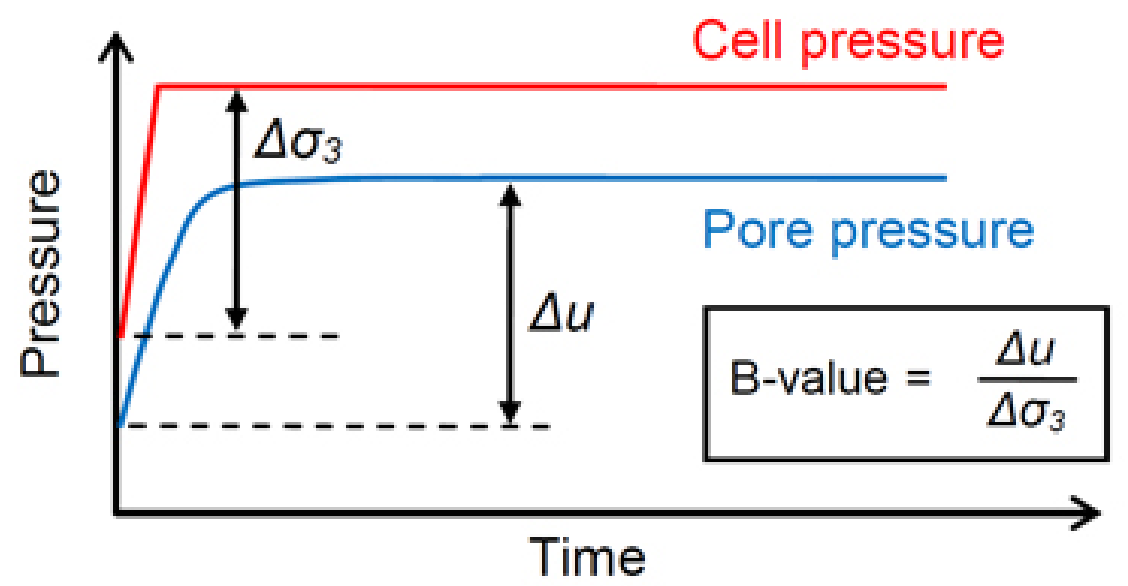

Figure 3-3 B-check to confirm specimen saturation (http://www.gdsinstruments.com)

\section{c) Consolidation}

The consolidation stage achieved by increasing the cell pressure and maintaining a constant back pressure at the same time. The consolidation process is continued until the change in volume is insignificant and at least $95 \%$ of the excess pore pressure has been dissipated. The consolidation behavior can also be used to estimate rate of strain for shearing in cohesive soil. This stage brings the specimen to the effective stress required for the shearing (Figure 3-4).

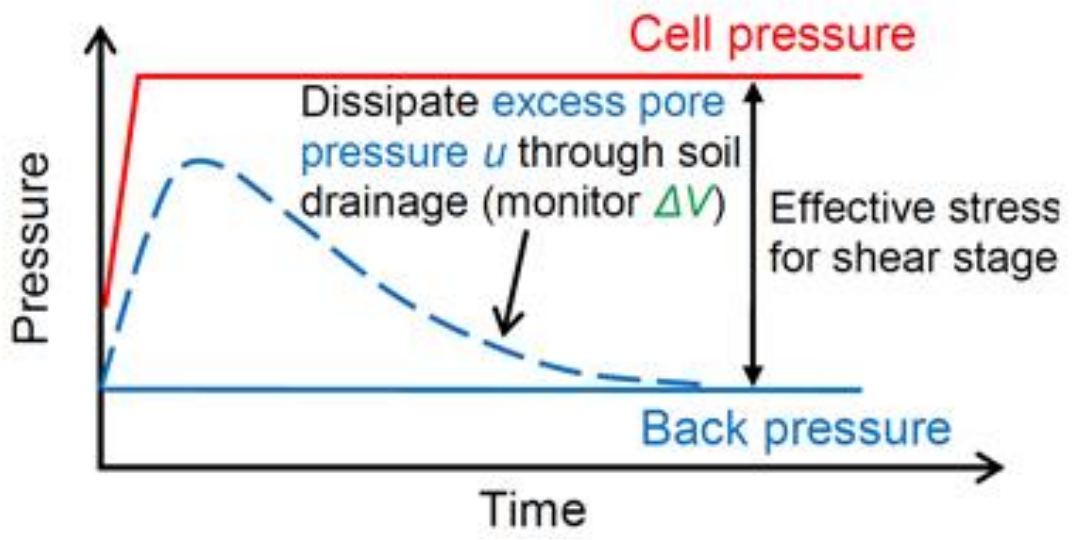

Figure 3-4 Consolidation stage (http://www.gdsinstruments.com) 
After the consolidation stage the sample goes under the shearing stage by applying the axial stress to the specimen at a constant rate whereas a constant confining pressure is maintained. The strain rate and drainage condition is dependent on the type of soil and test types.

The specimen response is monitored by plotting the deviator stress $q\left(\sigma_{1}-\sigma_{3}\right)$ and the effective principal stress ratio $\left(\sigma_{1}^{\prime} / \sigma_{3},\right)$ against the axial strain. The shearing continues until the specified failure criteria is reached. From this stage, one may identify peak deviator stress, or peak effective principal stress ratio, excess pore pressure and volume change values etc. The response of normally consolidated clay is shown in Figure 3-5. After the completion of shearing, the system can be dismantled and post-test moisture content is measured.
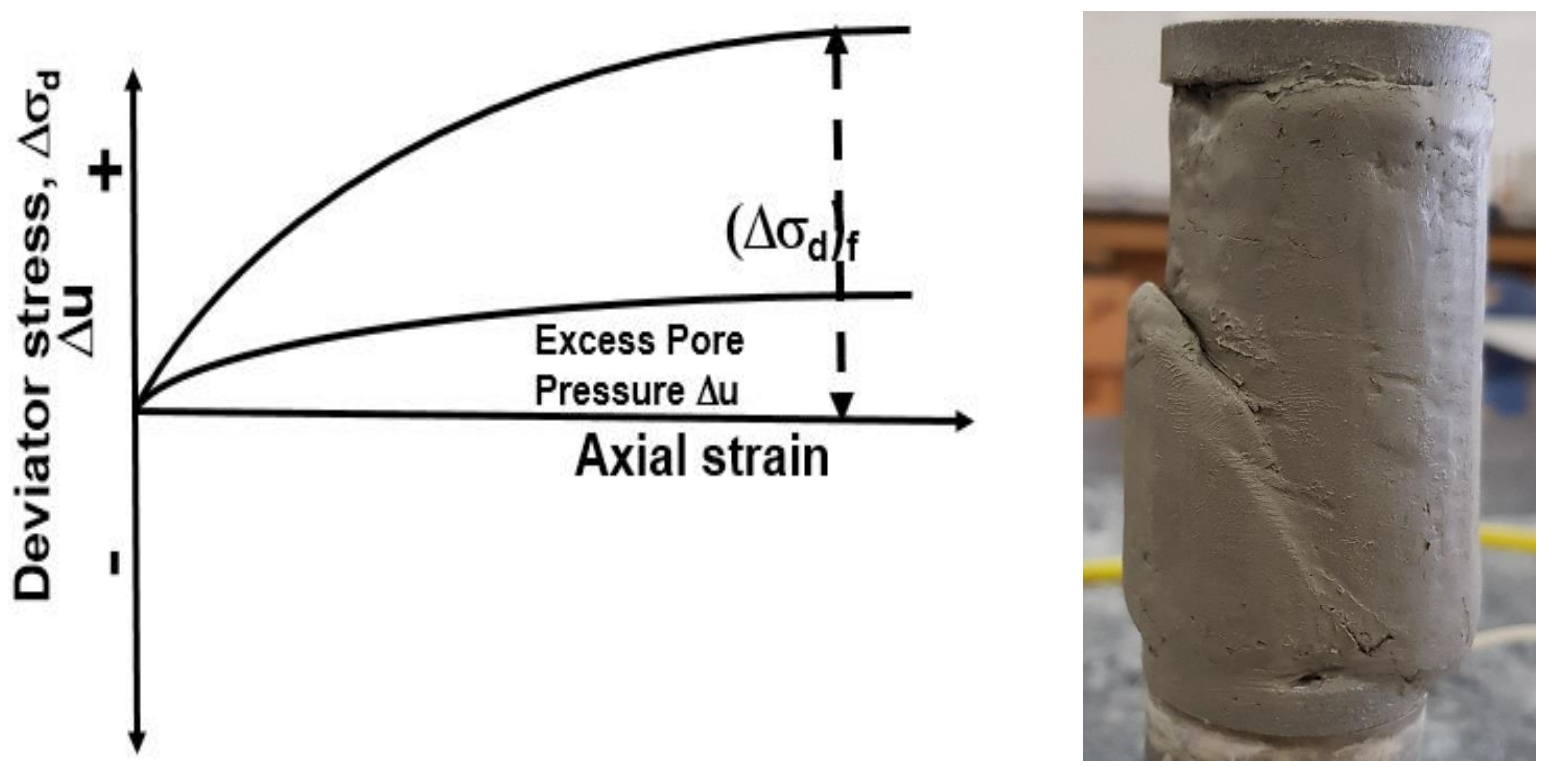

Figure 3-5 Specimen response of normally consolidated clay after shearing (left); Cohesive specimen post-shear showing failure plane (right). (from lab test)

\subsection{PRESENTING OF TEST RESULTS FROM TRIAXIAL TESTS}

The triaxial test must be conducted to closely simulate the stress path and stress history of the sample. Initially the confining pressure is applied and the sample is allowed for failure using 
deviator stress. The deviator stress can be calculated using the vertical stress over cross sectional area of the soil sample, ie.

Deviator stress $=\mathrm{P} / \mathrm{A}=\left(\sigma_{1}-\sigma_{3}\right)$

where:

$\mathrm{P}$ is shear force applied on soil sample

$\mathrm{A}$ is the cross sectional area of the soil sample;

$\sigma_{1}$ and $\sigma_{3}$ are the major (vertical) and minor (confining) principle stress

The deviator stress at failure $\left(\sigma_{1 \mathrm{f}}-\sigma_{3 \mathrm{f}}\right)$ is calculated deducting the minor principal stress from the major principal stress. Plot of deviator stress and the strain shows failure condition of the soil sample. The relationship with excess pore pressure and strain shows the change in pore pressure needed to fail the sample. The Mohr Coulomb failure criteria can be used to determine shear strength of the soil, apparent cohesion c', effective internal friction angle $\varphi$ ' and the effective normal stress $\sigma_{\mathrm{n}}$ along the failure plane. The failure criteria parameters c' and $\varphi$ ' can be obtained graphically from Mohr-Coulomb failure envelop.

Three undrained triaxial tests were performed with the confining pressures ranging from 385 to $635 \mathrm{kPa}$., Figure 3-6 shows the principal stress difference and the change in pore pressure vs. the axial strain. On the other hand, the pore pressure change shows initial positive increment indicates the volume change means the contraction but as shearing continues the pore pressure changes to negative values showing the suction behavior. The natural clayey soil fails progressively under the foundation. The strain softening behaviour should be considered to determine the progressive failure phenomenon. The elasto-plastic soil model for the clayey soil has limited capacity to model the behaviour. So, the most commonly used model, the Modified Cam Clay (MCC) model can use for heavily over-consolidated soil with high value of the ratio $\kappa / \lambda$, where $\lambda$ and $\kappa$ are respectively the slopes of virgin loading and the unloading-reloading lines in e- lnp' curve (e is void ratio) (Roscoe and Burland, 1968). 


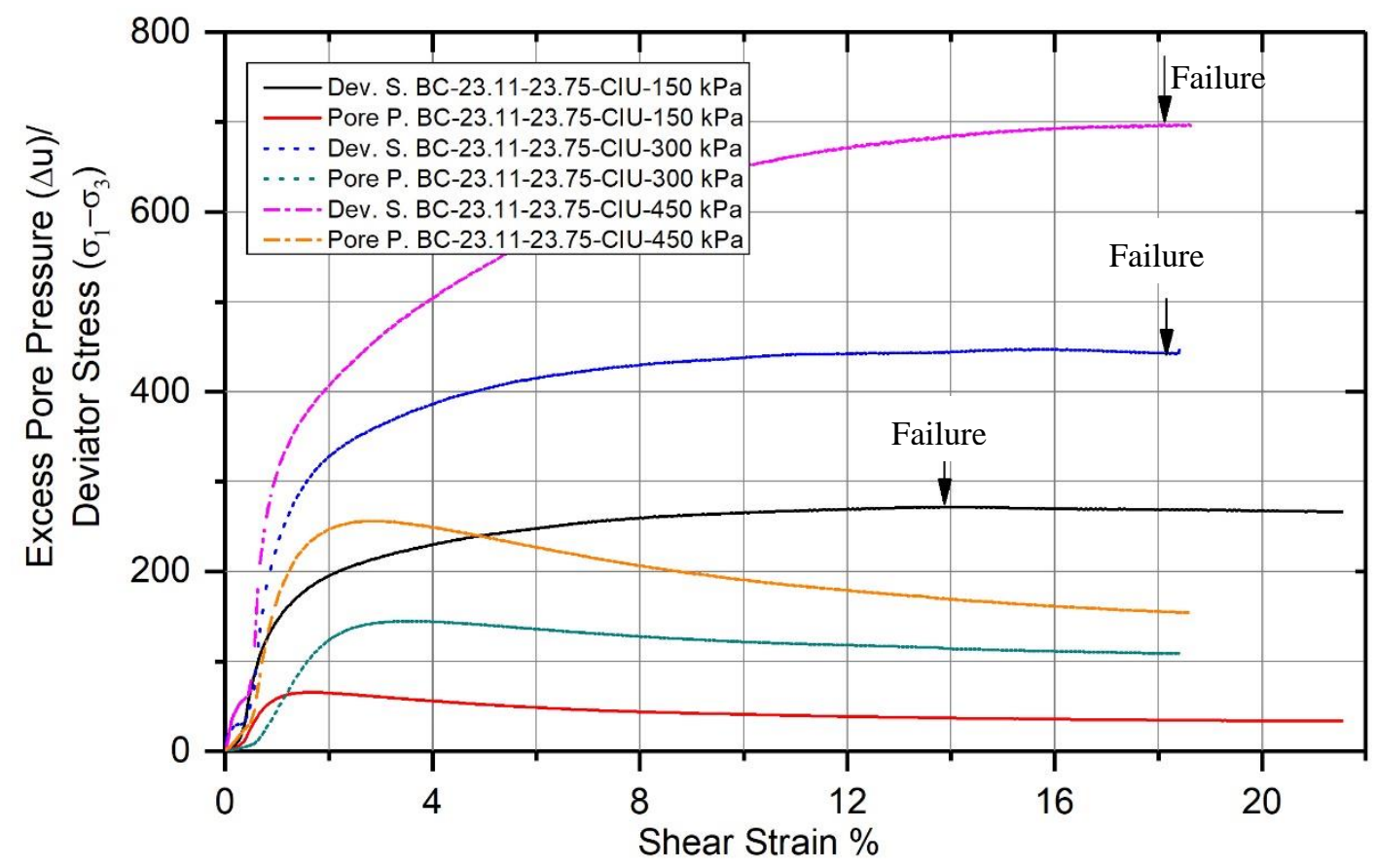

Figure 3-6 Black Creek station pore pressure and deviator stress vs shear strain

In Figure 3-6 it can be observed that the pore pressure rises and more or less constant even increased in strain. And also the deviator stress is increasing by increasing the strain that means the soil is normally consolidated. This figure also shows failure at different strain values and it is based on maximum deviator stress.

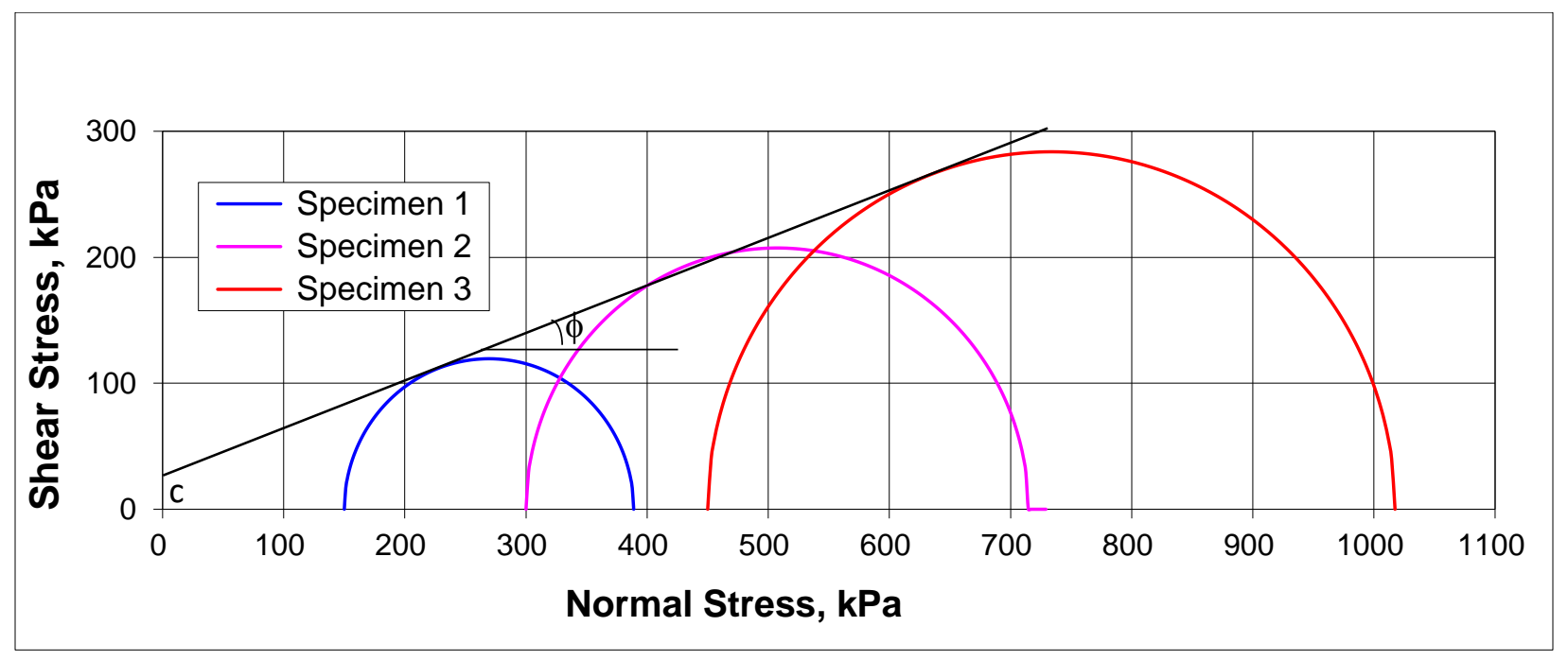

Figure 3-7 Black Creek station Mohr-Coulomb failure line 
From the Mohr Circle plot (Figure 3-7) the soil parameter cohesion (c) is $25 \mathrm{kPa}$ and the angle of internal friction angle $(\phi)$ is calculated as 22.55 degree. Other parameter such as undrained shear Modulus and failure strain are shown Table 3-1 below.

Table 3-1 The confining pressure and the failure strain on Black Creek Station 23m depth

\begin{tabular}{|c|c|c|}
\hline $\begin{array}{c}\text { Confining Pressure } \\
(\mathrm{kPa})\end{array}$ & $\begin{array}{c}\text { Undrained Shear } \\
\text { Modulus }(\mathrm{kPa})\end{array}$ & $\begin{array}{c}\text { Failure Strain } \\
(\%)\end{array}$ \\
\hline 335 & 8720.56 & 13.99 \\
\hline 365 & 19409.05 & 18.40 \\
\hline 655 & 11385.09 & 18.49 \\
\hline
\end{tabular}

\subsubsection{Stress-Path Method}

The stress path method is used to estimate settlement and is based on the axial strain measurements. The result of the undrained test with major stress directions shows that the undrained strength of the sandy soil depends on the loading direction and rotation of the major stress direction (Symes et. al. 1984). For the triaxial test, the soil sample disturbance maximizes the error so the conventional triaxial test procedure helps to reduce errors by applying relatively high confining pressure. The most important consideration of triaxial test is to analyze effect of over-consolidation by applying high confining pressure. The soil deposits in the GTA are mostly overconsolidated as the whole area was covered by thick ice sheets and now after removal they are under the vertical stress relaxation. The major components of sample disturbance is due to field removal and can be approximated by using in-situ stress condition and anisotropic consolidation.

A stress path is the representation of series of points of stress state that soil experienced during the triaxial test and can represented by Mohr Circle in the $\tau-\sigma$ coordinate system. The state of stress can also be represented by stress point having coordinates $\left(\sigma_{1}-\sigma_{3}\right) / 2$ and $\left(\sigma_{1}+\sigma_{3}\right) / 2$ as shown in Figure 3-8. For the triaxial test $\sigma_{1}$ and $\sigma_{3}$ act on vertical $\left(\sigma_{\mathrm{v}}\right)$ and horizontal $\left(\sigma_{\mathrm{h}}\right)$ planes and the stress points can simply q and p respectively; or

$$
q=\frac{\sigma_{v}-\sigma_{h}}{2}
$$




$$
p=\frac{\sigma_{v}+\sigma_{h}}{2}
$$

Here both $q$ and $p$ can be defined in terms of principal stresses and $q$ is considered positive when $\sigma_{\mathrm{v}}>\sigma_{\mathrm{h}}$, otherwise it is negative.

The shearing behavior can be seen clearly while plotting the effective mean principal stress and the principal stress difference ie. p'-q curve (Fig: 3-8). The stiffness and strength increases with the increase in initial confining pressure can be observed in the p'-q curves (Figure 3-8).

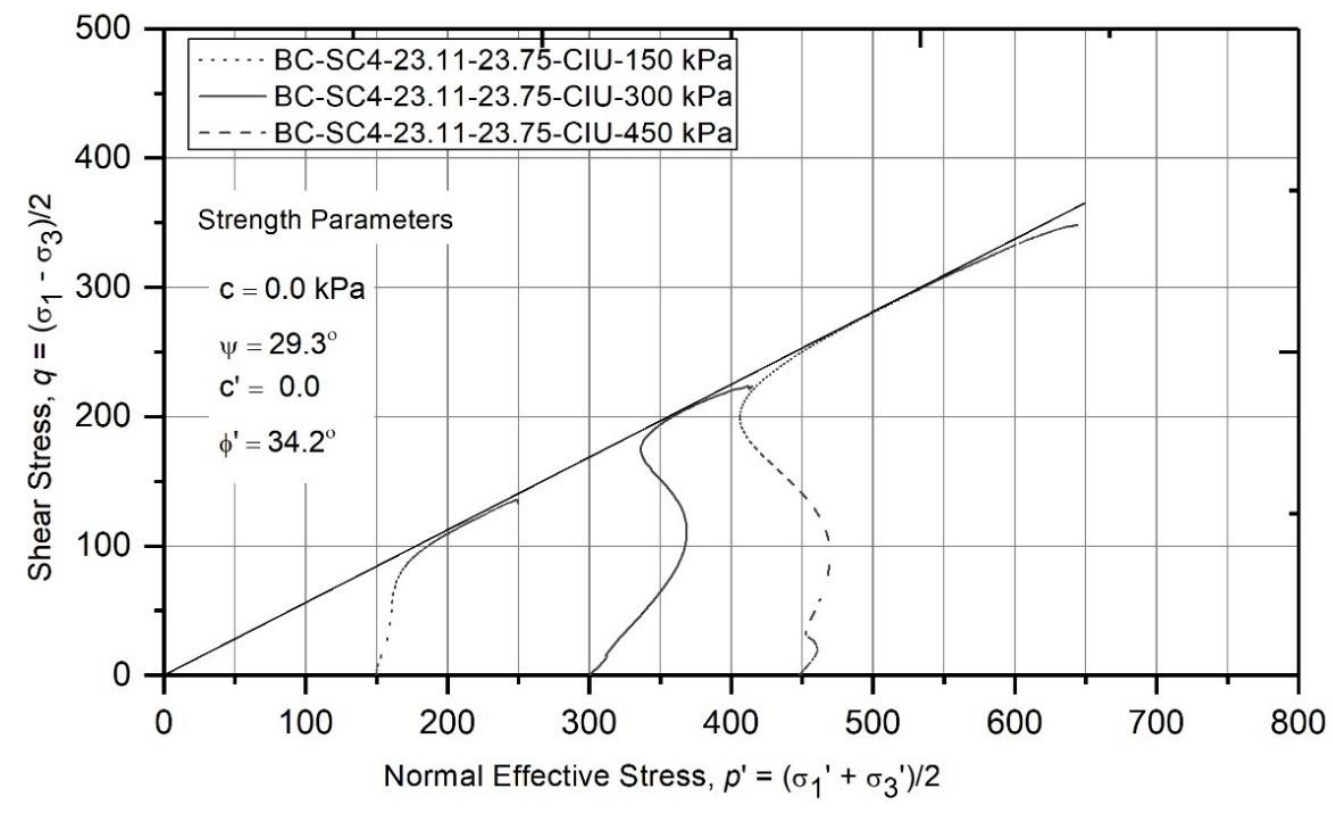

Figure 3-8 The p'-q curve of Black Creek station with the depth of 23.11-23.75m

Three triaxial tests conducted in the glacial till of GTA are shown in Figure 3-9 showing the effective principal stress vs. the principal stress difference. It can be observed that the shear strength parameters can be obtained from three tests under different confining pressures. 


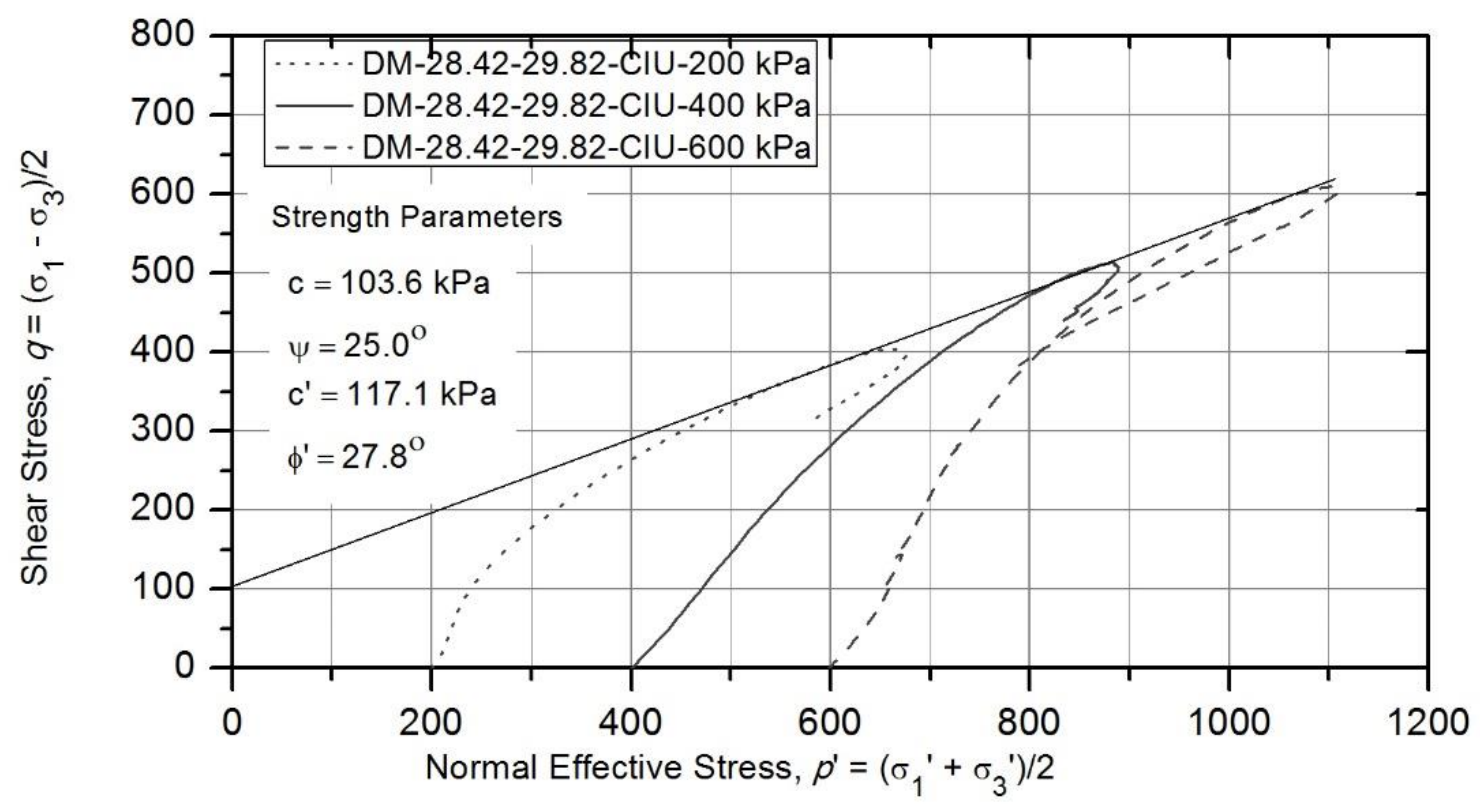

Figure 3-9 The p'-q curve of Don Mills station with the depth of $28.42-29.82 m$

\subsection{DETERMINATION OF SHEAR STRENGTH PARAMETERS FROM TRIAXIAL TESTS}

From this test, not only the angle of shearing resistance $\phi$ ' and cohesion $c^{\prime}$, and undrained shear strength $C_{u}$ can be obtained, and also other parameters such as compression index $C_{c}$, shear stiffness $G$ and permeability $k$ can be obtained. The test results are more fruitful to find the triaxial compression strength at cut slope and triaxial extension at the slope base.

\subsubsection{Failure Criterion and Failure Envelope}

For the failure criteria both the peak effective stress ratio and the peak principal stress difference (total stress) have been used to derive failure criteria for glacial till. In undrained test the principal stress difference depends on the soil properties, stress path and over consolidation ratio (OCR). Previously, the peak principal stress difference was used for the failure criterion (Henkel 1959; Parry and Nadarajah 1973). Later on, the peak effective principal stress ratio was used. In the consolidated undrained test, pore pressure variation can make the peak principal stress difference before or after the peak principal stress ratio occurs which makes difficulty for choosing the failure 
criteria (Simons 1960b). The relation between the failure criteria and the Mohr-Coulomb failure criteria are shown in figure 3-10.
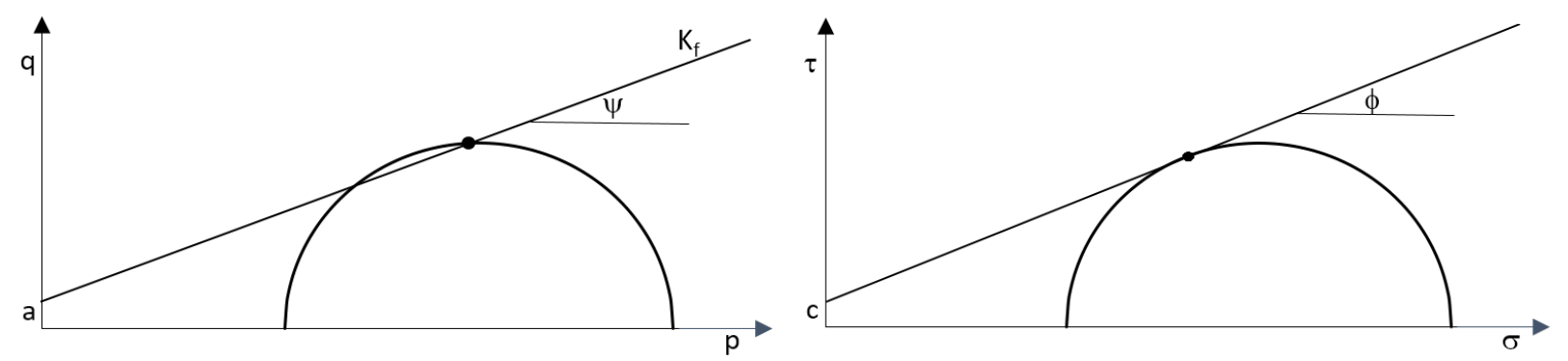

Figure 3-10 The relationship between the failure criteria (Left) and Mohr-Coulomb failure envelop

There are three different confining pressure 200, $400 \& 600 \mathrm{kPa}$ applied for the analysis of Don Mills Station at the depth of 28.42-29.82 (Figure 3-9). While increasing the confining pressure it is seen that the deviator stress also increased. On the other hand, the maximum deviator stresses achieved in early stages of strain development in the soil sample. The pore pressure changes in all the case of three different confining pressure initially increased and after some time the pressure will gradually decreases.

\subsubsection{Critical State}

The critical state theory is widely used for the interpretation of behavior of soils after pioneering work of Roscoe et al. (1958). The critical state is a condition of shearing of soils where the stress ratio $(\mathrm{M})$ or the critical state of friction angle $(\phi c)$ and the critical void ratio $(\varepsilon)$ reached. The condition can be formulated as:

$\frac{\delta p^{\prime}}{\delta \varepsilon q}=\frac{\delta \mathrm{p}}{\delta \varepsilon \mathrm{q}}=\frac{\delta v}{\delta \varepsilon q}=0$

The test of soil specimens describes the representation of a series of points. These points describe the path called critical state path, where the soil reached its maximum shear points and the unique 
line in the p'-q'-v space referred as critical state line (CSL) and is represented by the following equations:

$q=M p^{\prime}$

$v=\Gamma-\lambda \ln p^{\prime}$

Where $\mathrm{M}, \Gamma$ and $\lambda$ are soil constants

The critical state was identified at constant deviator stress with increasing axial strain. The critical state and the friction angle is determined by

$$
\sin \phi=\frac{\frac{\sigma^{\prime} 1}{\sigma^{\prime}}-1}{\frac{\sigma^{\prime} 1}{\sigma^{\prime} 3}+1}=\frac{\sigma^{\prime} 1-\sigma^{\prime} 3}{\sigma^{\prime} 1+\sigma^{\prime} 3}
$$

Where $\sigma_{1}{ }_{1}$ and $\sigma_{3}{ }_{3}$ are effective major and minor principal stresses respectively. The mean normal effective stress and deviator stresses used in the critical state determination by assuming the compressive stress and strains as positive defined in triaxial test condition $\sigma_{2}^{\prime}=\sigma_{3}^{\prime}$ as follows

$p^{\prime}=\frac{\sigma^{\prime} 1+\sigma^{\prime 3}}{2}$

$q=\sqrt{\left[\left(\sigma^{\prime} 1-\sigma^{\prime} 2\right)^{2}+\left(\sigma^{\prime} 2-\sigma^{\prime} 3\right)^{2}+\left(\sigma^{\prime} 3-\sigma^{\prime} 1\right)^{2}\right] / 2}=\left(\sigma^{\prime} 1-\sigma^{\prime} 3\right) / 2$

The triaxial test is very useful to define the critical state line in sandy soils. During the triaxial test the soil sample should reach a specific point p' (the effective mean principal stress), q (the principal stress difference) and e (void ratio). The effective stress of the soil and the void ratio become constant under critical state condition, and is called the ultimate or critical state and the void ratio at this time is called critical void ratio. The soil behavior observed in triaxial tests for overconsolidated specimens with zone failure supports the critical state theory (Tsai, 1985).

The triaxial tests showed that the end points of the stress path at the same applied stress in p'-q curve (Figure 3-11 and 3-12). The test was summarized using four different notations. The first two letter for the borehole station, followed by depth of the soil sample, then kind of test and at last the applied confining pressure. For example LA-32.12-33.15-CIU-666 kPa; here LA represent 
the Laird station; 32.12-33.15 represent the sample depth; CIU represent Consolidated Isotropic Undrained test; and $666 \mathrm{kPa}$ is applied confining pressure.

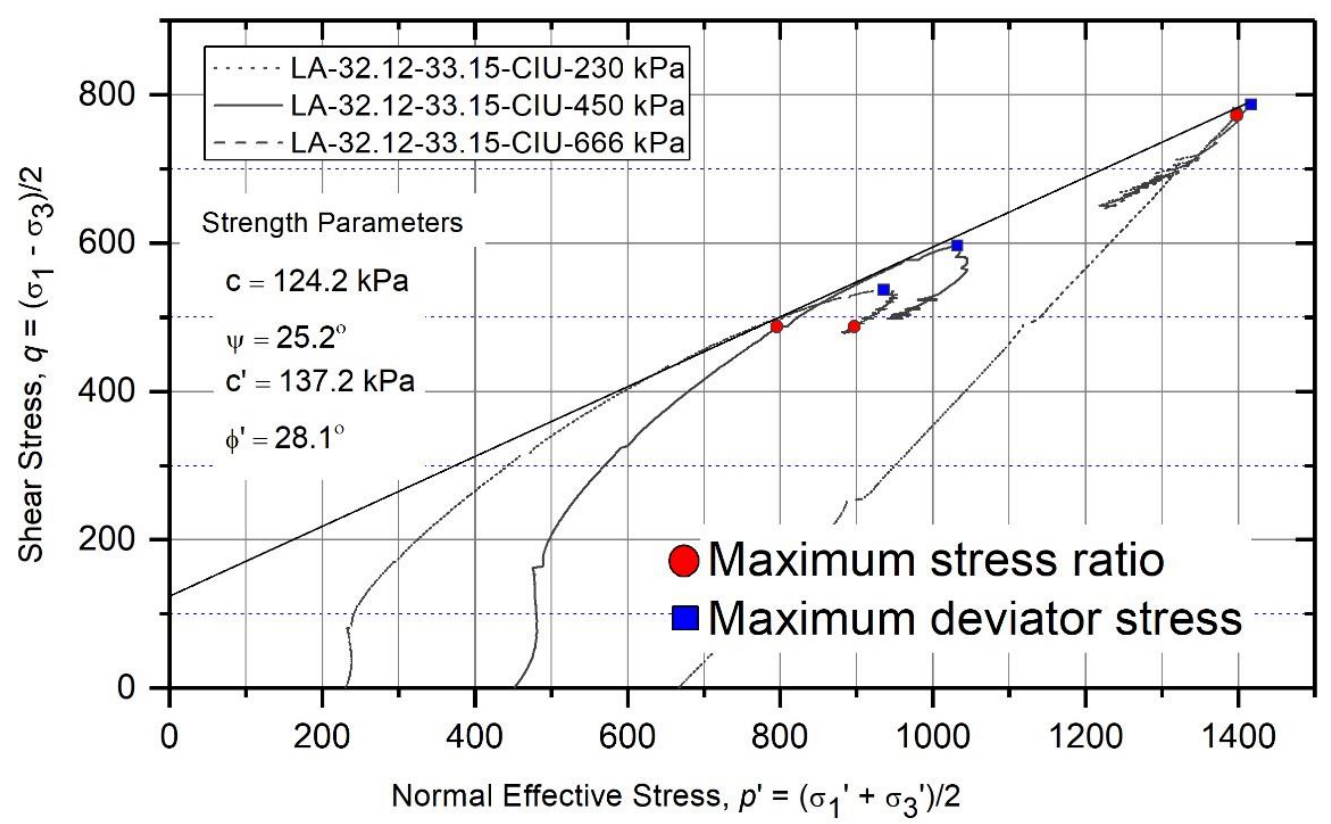

Figure 3-11 Critical State Line (CSL) is draw by joining the locus of the points

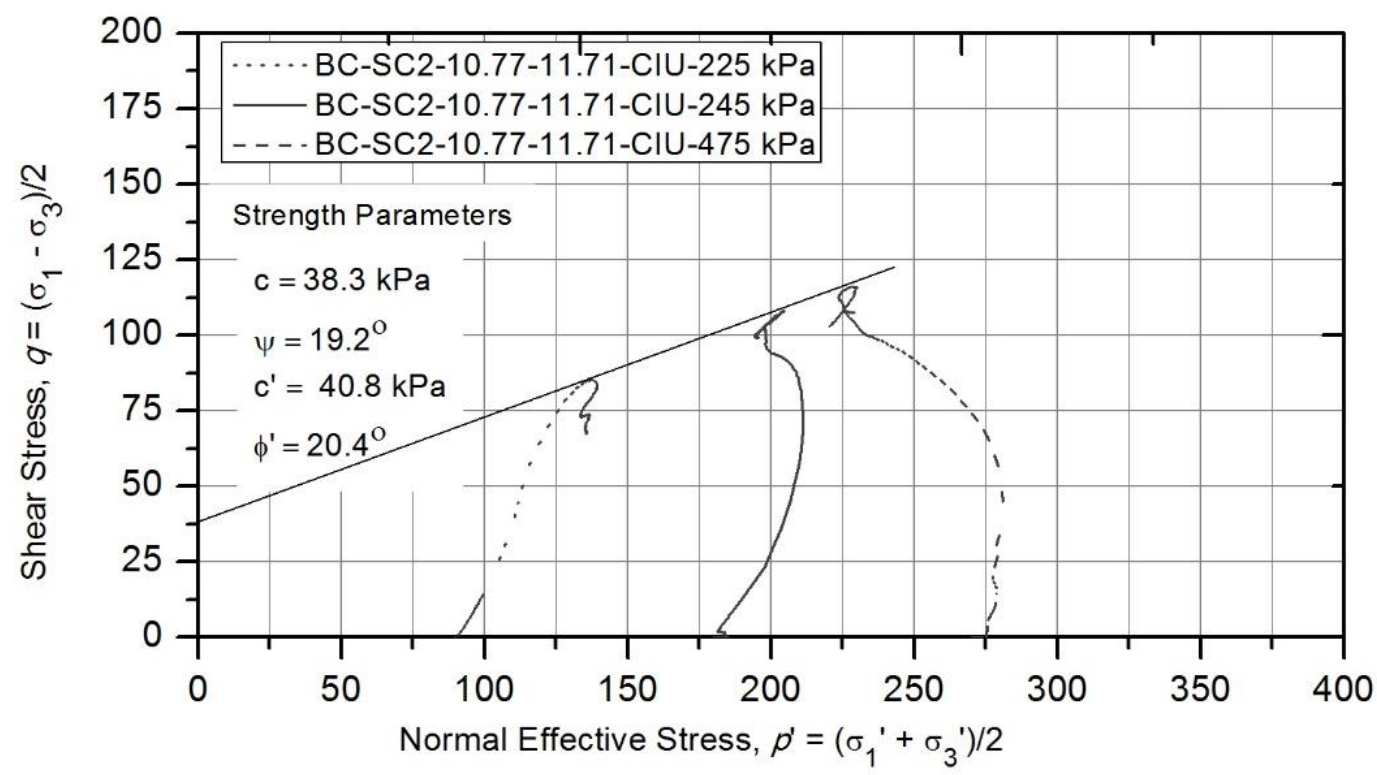

Figure 3-12 Critical State Line (CSL) is draw by joining the locus of the points of Black Creek station sample from 10.77-11.71m depth 


\subsubsection{Impact from Different Failure Criteria}

There are different methods in use to depict the failure criteria. Figure 3-13 shows 3 different ways of failure determination and calculated strength parameters. The maximum stress ratio is one of the common method. In this method the ratio between the major effective principal stresses to that minor effective principal stresses are used and if the ratio is highest then the failure is assumed to occur. On the other hand some of authors said the failure will occur when deviator stress is the maximum. Also the residual stress can be failure criteria. Among these criteria taken for the comparison it is found that the friction angle are more or less similar whereas the cohesion have some wide difference. For an example, the Don Mills station with the depth of $28.42-29.82 \mathrm{~m}$ having different stress combinations i.e. maximum stress ratio, maximum deviator stress and the residual stress is plotted (Figure 3-13) along with their cohesion and friction values.

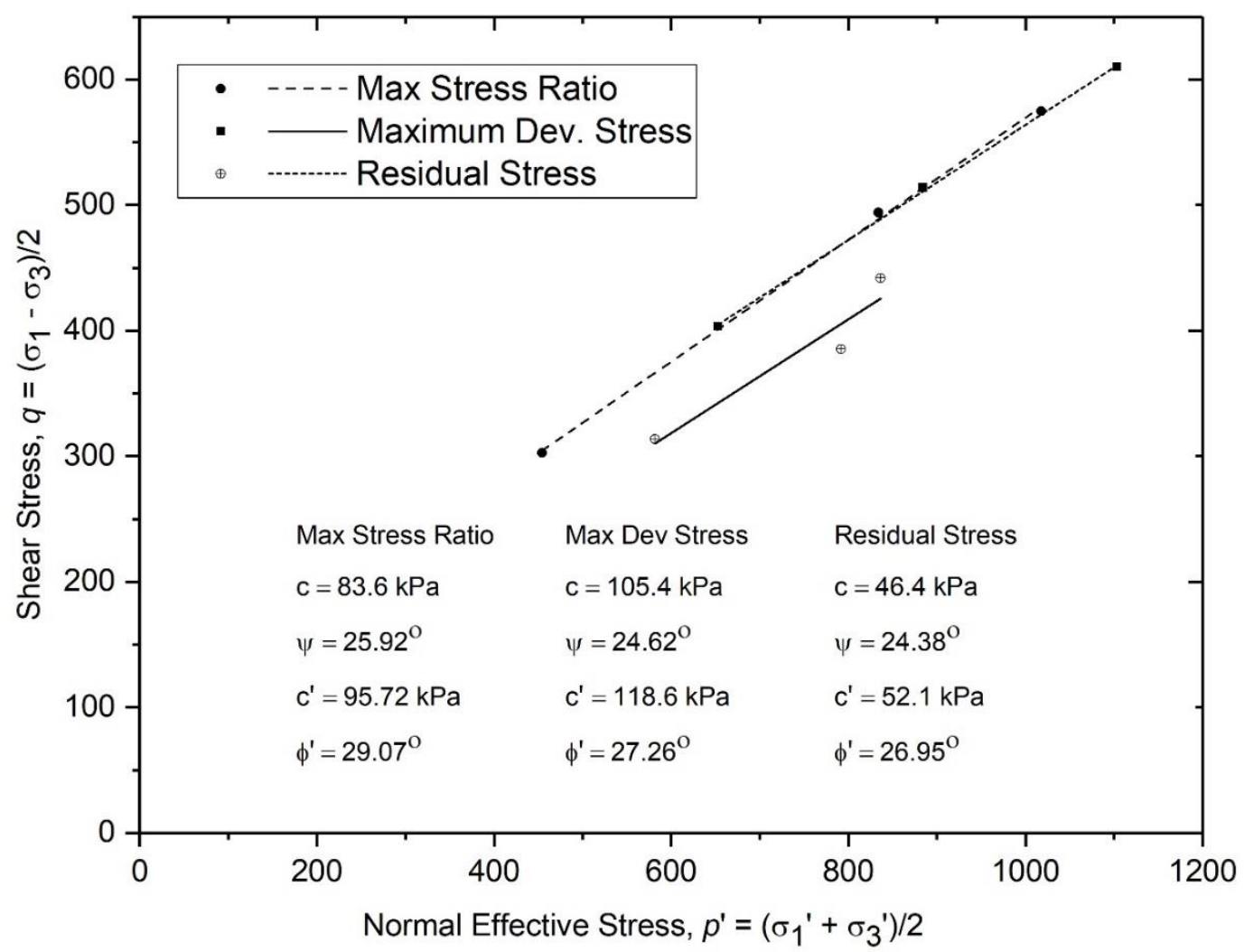

Figure 3-13 Different state of stresses with their characteristic values of Don Mills station at the depth of $28.42-29.82 m$ 


\subsubsection{Undrained Modulus Calculations}

The estimation of soil modulus is most difficult because of its heterogeneous nature. The stress strain curve is obtained from triaxial test can be used to determine the modulus. The sample is cylindrical; wrapped by impermeable membrane and confined by hydrostatic pressure. Afterward the vertical stress increased gradually and assumed that the strains exerted in soil are linearly related with the stresses applied. But in reality there is no such linearity is obtained from the test. The stress strain curve which is non-linear obtained from triaxial test is shown in figure below. Due to non-linear stress strain curve there are different modulus can obtained such as tangent, secant, and/or cyclic loading-unloading moduli. In our case the undrained shear modulus is calculated using the modulus from the stress strain curve, two points $1 / 3$ and $2 / 3$ of deviator stress chosen and slope of these two points are taken as shown in Figure 3-14 and found that the undrained modulus is $5677.9 \mathrm{kPa}$.

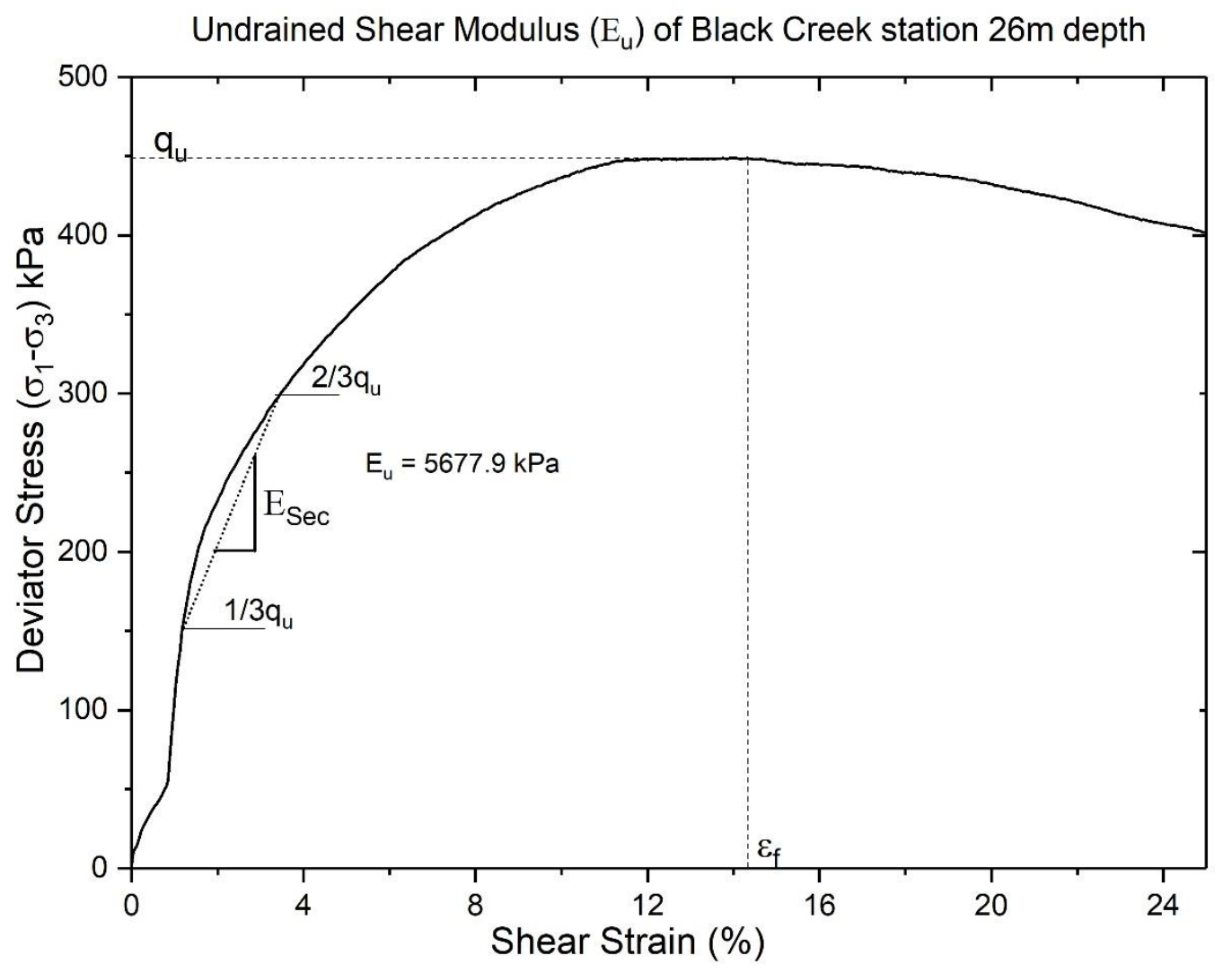

Figure 3-14 An Example of Secant modulus calculation of Black Creek Station 26m depth 


\subsection{SUMMARY}

Present chapter discusses test procedure and test results in terms of shear strength of the soil. First, the excess pore water pressure and deviator stress versus shear strain graph gives the concept of the normally consolidated soils. How the curve looks like and what are the possibilities. From the Mohr-Circle plotting the shear strength parameters can obtained and mostly similar results to that of the plots of normal effective stress versus shear stress. In addition, other factors to determine the shear failure such as maximum stress ratio and maximum deviator stress and their parameter similarities can obtain. The parameters are similar to each other in terms of the failure angle whereas the cohesion values are different. Furthermore, the undrained shear modulus of the soil is also calculated using $1 / 3^{\text {rd }}$ and $2 / 3^{\text {rd }}$ values and their slope angle. 


\section{CHAPTER 4 STATISTICAL ANALYSIS OF SHEAR STRENGTH PARAMETERS OF FINE- GRAINED GLACIAL TILLS}

\subsection{INTRODUCTION}

The soil shear strength parameters are calculated from the triaxial test raw data and analyzed statistically. A total of $174 \mathrm{CU}$ triaxial tests are taken into consideration for this analysis. All the raw data are obtained within 16 different stations from the ECLRT project. From the data, information about soil type, highest stress/strain ratios, pore pressure, radial pressure, friction angle, water content, maximum deviator stress, maximum pore pressure were obtained. These data are processed performing simple statistical analysis. The consolidation test using Oedometer was used to get overconsolidation ratio of the glacial deposits.

In glacial deposits, the history of soil sediment is important to determine the future response of applied load after the construction of any infrastructure. A soil which has never experienced an effective stress greater than presently experiencing is called normally consolidated soil. Whereas the overconsolidated soil has experienced greater effective stress in past than it is in presently experienced. In case of overconsolidated soil, the preconsolidation pressure is the maximum applied effective stress. The preconsolidation pressure can be determined in laboratory by conducting the one dimensional consolidation test.

$$
O C R=\frac{\sigma_{p c^{\prime}}}{\sigma_{v^{\prime}}}
$$

Where $\sigma_{p c}$ is preconsolidation pressure and $\sigma_{v}$ is the effective vertical stress due to current overburden. In general the OCR is always $\geq 1$. For the normally consolidated soil OCR is equal to 1. 


\subsubsection{Triaxial Tests Conducted at Don Mills Station}

In the Don Mills station 13 grainsize analysis and 13 Atterberg Limit tests were conducted. Most of the grain sizes are clay and fine silt whereas only a few soil samples contain a higher proportion of sand and gravel. The lowest liquid limit is 17 and highest is 45 whereas most of the soil have their liquid limit ranging from 27 to 35. In the Don Mills station, three sets of triaxial tests were done at different depths (20m, 23m and 29m) of borehole number DM100B. Among these 3 sets of triaxial test different confining pressures have been used. The details of depth and the confining pressure are presented Table 4-1.

Table 4-1 Different parameter used to conduct triaxial test of different depth

\begin{tabular}{|l|c|c|}
\hline $\begin{array}{l}\text { Borehole } \\
\text { Number }\end{array}$ & $\begin{array}{c}\text { Sample Number / } \\
\text { Depth }\end{array}$ & $\begin{array}{c}\text { Confining } \\
\text { Pressure }(\mathrm{kPa})\end{array}$ \\
\hline \multirow{2}{*}{ DM 100 B } & SC 17/ & 335 \\
\cline { 3 - 3 } & $28-29 \mathrm{~m}$ & 465 \\
\hline \multirow{2}{*}{ DM 100 B } & SC 12, 13 / & 735 \\
\cline { 3 - 3 } & $20-21 \mathrm{~m}$ & 285 \\
\hline \multirow{2}{*}{ DM 100 B } & SC14 / & 565 \\
\cline { 3 - 3 } & $23-25 \mathrm{~m}$ & 380 \\
\hline
\end{tabular}

From the consolidation test, it is found that the preconsolidation pressure is around 200 (Figure 41). The confining pressure applied for the triaxial test are higher than preconsolidation pressure that obtained from the Oedometer test. In this context, the soil experiences higher confining pressure that it experienced before so the overconsolidation ratio would be 1, or the sample will be normally consolidated. It can clearly observed from table 4-1 and figure 4-1 all triaxial test had done higher confining stresses and their OCR would be 1 . 


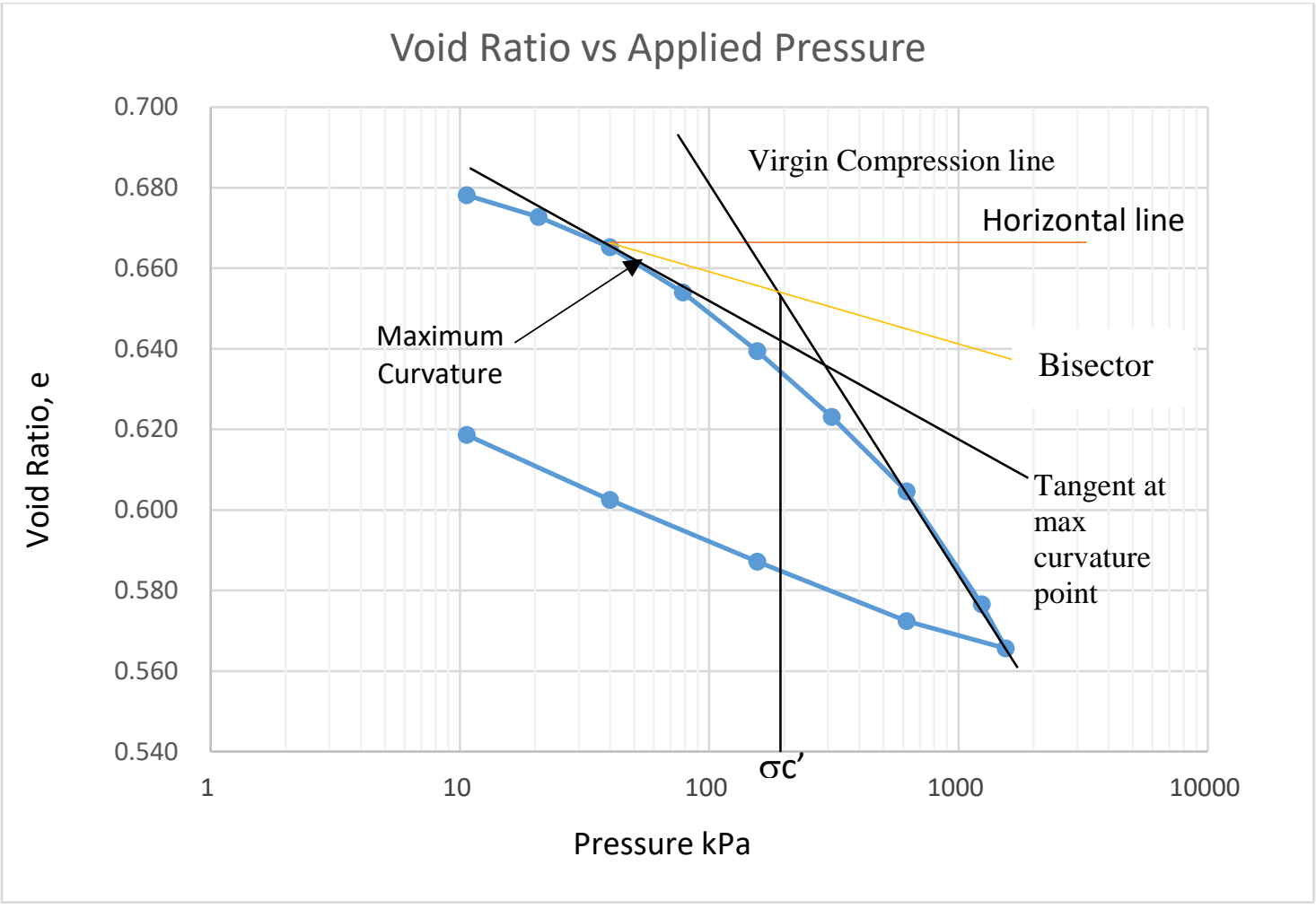

Figure 4-1 Estimation of Preconsolidation pressure at a depth 27.71m of Don Mills Station using Casagrande method

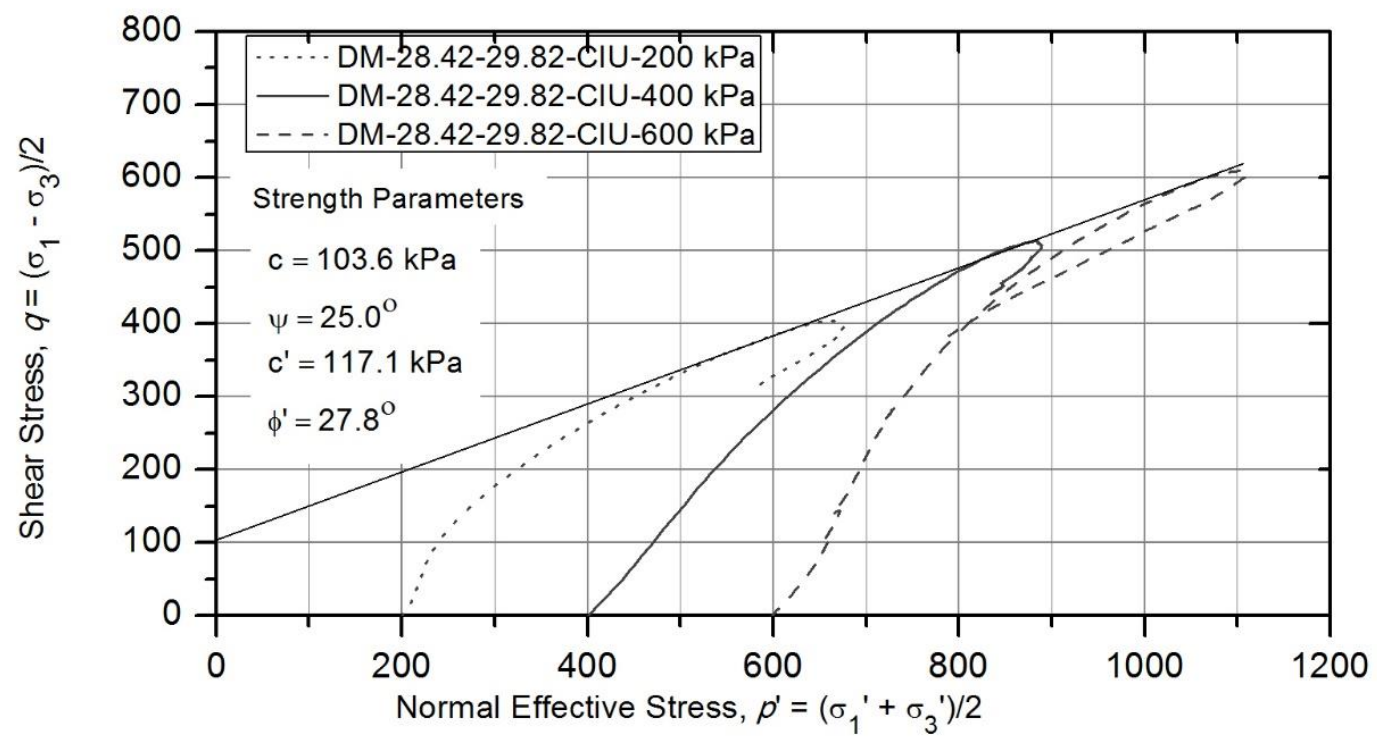

Figure 4-2 Stress Path (p’-q) curve of Don Mills station at depth of 28.42-29.82m 
From the plotting of p'-q curve (Figure 4-2) cohesion and friction of the soil are estimated to be $103.6 \mathrm{kPa}$ and 25.0 degrees whereas effective cohesion and friction are $117.1 \mathrm{kPa}$ and 27.8 degrees, respectively. The p'-q curve, figure of deviator stress and change in pore pressure vs strain of all analyses are included and the details of all other stations and tests are described on separate headings.

\subsection{STATISTICAL ANALYSIS OF FINE-GRAINED TILLS IN GTA}

The plotting of maximum stress ratio, maximum deviator stress and residual stress have similar friction angle and only the cohesion values varies a lot. All other calculated data are summarized in the table below (Table 4-2 and 4-3).

The lateral stress ratio $\mathrm{K}$ is the ratio of horizontal to vertical stresses, and the stress ratio at failure can calculate using formula

$$
K_{f}=\frac{\sigma_{h f}}{\sigma_{v f}}
$$

It is most important to know the condition at failure and relationship between the $K_{f}$ line and MohrCoulomb failure envelop. There is some variation between the failure surface that draw using $p-q$ curve and using Mohr $\tau-\sigma$ diagram. To correlate between these two lines and their intercepts there were several Mohr circle and stress paths were used. The equation of $K_{f}$ line changes to:

$q_{f=}=a+p_{f} \tan \psi$

where $\mathrm{a}=$ intercept on the q-axis in stress unit and

$\psi=$ the angle of the $\mathrm{K}_{\mathrm{f}}$ line

For the Mohr-Coulomb failure envelop the equation would be

$\tau_{f f}=\sigma_{f f} \tan \phi+c$

By rearranging equation 4-3 and 4-4 we can get

$\sin \phi=\tan \psi$ and $c=a / \cos \phi$

Using the equation 4-5 all the values were calculated and presented on Table 4-2. 
Table 4-2 Calculation of cohesion (a), friction angle ( $\psi$ ) and cohesion (c'), friction angle ( $\left.\phi^{\prime}\right)$ of soil based on the maximum stress ratio and maximum deviator stress

\begin{tabular}{|c|c|c|c|c|c|c|c|c|c|}
\hline \multirow[b]{2}{*}{ Stations } & \multirow[b]{2}{*}{ Soil Type } & \multicolumn{4}{|c|}{ Max Stress Ratio } & \multicolumn{4}{|c|}{ Max Dev Stress } \\
\hline & & $\begin{array}{c}\text { Friction } \\
\text { Angle } \\
(\psi) \\
\text { degrees }\end{array}$ & $\begin{array}{c}\text { Friction } \\
\text { Angle }\left(\phi_{c}\right) \\
\text { degrees }\end{array}$ & $\begin{array}{c}\text { Cohesion } \\
\qquad \begin{array}{c}(a) \\
\mathrm{kPa}\end{array}\end{array}$ & $\begin{array}{c}\text { Cohesion } \\
\left(\mathrm{c}^{\prime}\right) \\
\mathrm{kPa}\end{array}$ & $\begin{array}{c}\text { Friction } \\
\text { Angle } \\
(\psi) \\
\text { degrees }\end{array}$ & $\begin{array}{c}\text { Friction } \\
\text { Angle }\left(\phi_{c}\right) \\
\text { degrees }\end{array}$ & $\begin{array}{c}\text { Cohesion } \\
(a) \\
\mathrm{kPa}\end{array}$ & $\begin{array}{c}\text { Cohesio } \\
\mathrm{n}\left(\mathrm{c}^{\prime}\right) \\
\mathrm{kPa}\end{array}$ \\
\hline DM-1 & Clayey Silt & 30.20 & 35.59 & 4.79 & 5.88 & 30.20 & 35.59 & 4.79 & 5.88 \\
\hline DM-2 & Clayey Silt & 25.45 & 28.42 & 48.20 & 54.80 & 25.79 & 28.90 & 41.90 & 47.86 \\
\hline Allen-2 & Silty clay & 33.56 & 41.55 & 62.18 & 83.09 & 34.07 & 42.56 & & \\
\hline Allen-3 & Clayey Silt Till & 30.28 & 35.73 & 77.87 & 95.93 & 31.38 & 37.58 & & \\
\hline Allen-4 & Clayey Silt Till & 28.60 & 33.04 & 40.44 & 48.24 & 31.14 & 37.18 & & \\
\hline Allen-5 & Clayey Silt Till & 31.77 & 38.27 & 7.65 & 9.75 & 31.47 & 37.74 & & \\
\hline Avenue-1 & Silty Clay Till & 21.55 & 23.26 & 109.00 & 118.64 & 28.66 & 33.13 & & \\
\hline Bathurst-2 & Silty clay & 30.49 & 36.07 & 0.00 & 0.00 & 30.75 & 36.51 & 0.00 & 0.00 \\
\hline Bathurst-3 & Silty Clay Till & 28.61 & 33.06 & 3.90 & 4.65 & 25.85 & 28.97 & 17.60 & 20.12 \\
\hline Bathurst-4 & Silty clay & 26.90 & 30.48 & & & 26.07 & 29.29 & & \\
\hline Bermonsday-1 & Silty Clay Till & 27.06 & 30.72 & 24.14 & 28.08 & 27.94 & 32.03 & 14.10 & 16.63 \\
\hline Bermonsday-2 & Silty Clay Till & 21.03 & 22.61 & 6.10 & 6.61 & 20.97 & 22.53 & 3.78 & 4.09 \\
\hline Bermonsday-3 & Silty Clay Till & 19.11 & 20.27 & 11.66 & 12.43 & 18.23 & 19.23 & 14.60 & 15.46 \\
\hline Black Creek-1 & Silty Clay & 18.60 & 19.66 & 39.28 & 41.71 & 18.68 & 19.76 & 38.70 & 41.12 \\
\hline Black Creek-2 & Clayey Silt Till & 29.30 & 34.13 & 0.40 & 0.48 & 28.04 & 32.18 & & \\
\hline Black Creek-3 & Clayey Silt Till & 29.85 & 35.02 & 5.15 & 6.29 & 27.54 & 31.43 & 32.68 & 38.30 \\
\hline Black Creek-4 & Clayey Silt Till & 27.23 & 30.97 & 4.90 & 5.71 & 26.60 & 30.05 & & \\
\hline Young-4 & Clayey Silt & 27.52 & 31.39 & 79.51 & 93.14 & 26.59 & 30.03 & 19.19 & 22.17 \\
\hline Dufferin-1 & Clayey Silt Till & 29.14 & 33.89 & 114.96 & 138.49 & 27.61 & 31.53 & 159.47 & 187.08 \\
\hline Dufferin-2 & Clayey Silt Till & 30.54 & 36.16 & 99.74 & 123.54 & 29.83 & 34.98 & 111.75 & 136.39 \\
\hline Laird-1 & Silty Clay & 29.61 & 34.64 & 50.71 & 61.63 & 29.16 & 33.91 & 44.47 & 53.58 \\
\hline Laird-2 & Silty Clay & 26.86 & 30.42 & 75.28 & 87.30 & 27.31 & 31.09 & 56.02 & 65.42 \\
\hline Laird-3 & Silty Clay & 27.72 & 31.70 & 45.26 & 53.20 & 26.96 & 30.57 & 66.55 & 77.29 \\
\hline Mount Dennis-1 & Clayey Silt & 27.03 & 30.68 & & & 26.48 & 29.88 & & \\
\hline Mount Dennis-2 & Clayey Silt Till & 29.17 & 33.94 & & & 28.37 & 32.68 & & \\
\hline Mount Dennis-3 & Silty Clay & 28.85 & 33.43 & & & 27.95 & 32.05 & & \\
\hline Oakwood-1 & Silty Clay & 24.28 & 26.81 & 73.16 & 81.97 & 24.40 & 26.97 & 70.55 & 79.16 \\
\hline Oakwood-2 & Clayey Silt Till & 25.66 & 28.72 & 85.97 & 98.03 & 24.17 & 26.67 & 133.99 & 149.94 \\
\hline Oakwood-3 & Silty Clay Till & 31.92 & 38.53 & 1.20 & 1.53 & 28.44 & 32.79 & 18.70 & 22.24 \\
\hline Victoria Park-1 & Clayey Silt Till & 28.44 & 32.79 & 9.55 & 11.36 & 27.95 & 32.04 & 10.81 & 12.75 \\
\hline Victoria Park-2 & Clayey Silt Till & 28.10 & 32.27 & 9.07 & 10.73 & 27.90 & 31.97 & 9.60 & 11.32 \\
\hline
\end{tabular}




\begin{tabular}{|l|l|l|l|l|c|c|c|c|c|} 
Victoria Park-3 & Silty Clay Till & 30.07 & 35.38 & & & 29.79 & 34.92 & & \\
\hline West Port-1 & Silty Clay Till & 27.42 & 31.25 & 13.00 & 15.21 & 27.23 & 30.98 & 5.90 & 6.88 \\
\hline West Port-2 & Silty Clay Till & 29.95 & 35.18 & & & 29.14 & 33.88 & & \\
\hline West Port-3 & Silty Clay & 27.58 & 31.49 & & & 27.20 & 30.93 & & \\
\hline West Port-4 & Silty Clay Till & 28.56 & 32.98 & 5.15 & 6.14 & 28.39 & 32.71 & 6.79 & 8.07 \\
\hline Wynford-1 & Clayey Silt Till & 26.41 & 29.78 & 20.36 & 23.46 & 25.21 & 28.08 & 26.66 & 30.22 \\
\hline Wynford-2 & Silty Clay & 23.37 & 25.60 & 14.70 & 16.30 & 23.83 & 26.21 & 5.28 & 5.88 \\
\hline Wynford-3 & Silty Clay Till & 30.94 & 36.83 & & & 29.91 & 35.11 & & \\
\hline Chaplin-1 & Clay & 20.14 & 21.52 & 16.12 & 17.33 & 18.44 & 19.48 & 21.99 & 23.32 \\
\hline Chaplin-2 & Silty Clay & 23.44 & 25.69 & 68.29 & 75.78 & 25.06 & 27.87 & 36.98 & 41.83 \\
\hline Chaplin-3 & Silty Clay & 22.9 & 25 & 117.31 & 117.61 & 22.8 & 24.86 & & \\
\hline Chaplin-4 & Silty Clay & 22.88 & 24.96 & 44.61 & 49.21 & 21.69 & 23.43 & 52.63 & 57.36 \\
\hline Chaplin-5 & Silty Clay & 23.34 & 25.56 & 0.18 & 0.20 & 22.73 & 24.77 & & \\
\hline Chaplin-6 & Silty Clay & 27.37 & 31.17 & 35.04 & 40.95 & 27.39 & 31.20 & 16.54 & 19.34 \\
\hline Chaplin-7 & Clay & 27.24 & 30.99 & & & 26.88 & 30.45 & & \\
\hline Chaplin-8 & Silty Clay & 29.19 & 33.96 & & & 27.38 & 31.20 & & \\
\hline & St. Deviation & 3.81 & 5.59 & 47.05 & 52.01 & 3.58 & 5.13 & 45.10 & 51.02 \\
\hline & Max & 35.26 & 44.99 & 215.58 & 231.72 & 34.26 & 42.93 & 162.50 & 187.08 \\
\hline & Min & 18.60 & 19.66 & 0.18 & 0.20 & 18.05 & 19.02 & 1.08 & 1.28 \\
& Mean & 27.53 & 31.76 & 44.92 & 51.26 & 26.96 & 30.86 & 43.30 & 49.41 \\
\hline
\end{tabular}

Table 4-3 Calculation of cohesion (a), friction angle ( $\psi$ ) and cohesion (c'), friction angle ( $\phi$ )of soil based on the residual stress

\begin{tabular}{|l|l|c|c|c|c|}
\hline & & \multicolumn{4}{|c|}{ Residual } \\
\hline \multicolumn{1}{|c|}{ Stations } & \multicolumn{1}{|c|}{ Soil Type } & $\begin{array}{c}\text { Friction } \\
\text { Angle } \\
(\psi) \\
\text { degrees }\end{array}$ & $\begin{array}{c}\text { Friction } \\
\text { Angle } \\
\left(\phi_{\mathrm{c}}\right) \\
\text { degrees }\end{array}$ & $\begin{array}{c}\text { Cohesion } \\
(a) \\
\mathrm{kPa}\end{array}$ & $\begin{array}{c}\text { Cohesion } \\
(\mathrm{c}) \\
\mathrm{kPa}\end{array}$ \\
\hline DM-1 & Clayey Silt & 30.20 & 35.59 & 4.79 & 5.88 \\
\hline DM-2 & Clayey Silt & 27.35 & 31.15 & 2.49 & 2.91 \\
\hline DM-3 & Silty Clay & 24.38 & 26.95 & 46.45 & 52.11 \\
\hline Allen-1 & Clayey Silt Till & 29.24 & 34.04 & & \\
\hline Allen-2 & Silty clay & 30.61 & 36.28 & & \\
\hline Allen-3 & Clayey Silt Till & 29.22 & 34.01 & & \\
\hline Allen-4 & Clayey Silt Till & 29.88 & 35.06 & & \\
\hline Allen-5 & Clayey Silt Till & 30.20 & 35.58 & & \\
\hline Avenue-1 & Silty Clay Till & 28.66 & 33.13 & & \\
\hline Avenue-2 & clay & 21.13 & 22.73 & & \\
\hline Avenue-3 & Silty Clay & 21.22 & 22.64 & & \\
\hline Bathurst-1 & Silty Clay Till & 28.28 & 32.55 & 14.18 & 16.82 \\
\hline Bathurst-2 & Silty clay & 24.97 & 27.75 & & \\
\hline Bathurst-3 & Silty Clay Till & 25.19 & 28.05 & & \\
\hline Bathurst-4 & Silty clay & 19.53 & 20.78 & & \\
\hline Bermonsday-1 & Silty Clay Till & 27.74 & 31.74 & 6.96 & 8.18 \\
\hline Bermonsday-2 & Silty Clay Till & 19.97 & 21.30 & 6.16 & 6.61 \\
\hline Bermonsday-3 & Silty Clay Till & 19.54 & 20.79 & 1.80 & 1.93 \\
\hline Black Creek-1 & Silty Clay & 22.75 & 24.79 & 13.80 & 15.20 \\
\hline
\end{tabular}




\begin{tabular}{|c|c|c|c|c|c|}
\hline Black Creek-2 & Clayey Silt Till & 26.85 & 30.41 & 2.67 & 3.10 \\
\hline Black Creek-3 & Clayey Silt Till & 28.06 & 32.21 & 10.48 & 12.39 \\
\hline Black Creek-4 & Clayey Silt Till & 26.26 & 29.56 & & \\
\hline Black Creek-5 & Clayey Silt Till & 28.34 & 32.64 & & \\
\hline Black Creek-6 & Clayey Silt Till & 28.34 & 32.64 & & \\
\hline Caledonia-1 & Silty Clay & 27.78 & 31.79 & & \\
\hline Caledonia-2 & Silty Clay & 25.80 & 28.90 & & \\
\hline Young-1 & Silty Clay & 23.34 & 25.56 & & \\
\hline Young-2 & Silty Clay Till & 27.88 & 31.94 & & \\
\hline Young-3 & Clay & 19.95 & 21.28 & 18.49 & 19.84 \\
\hline Young-4 & Clayey Silt & 23.20 & 25.37 & 63.90 & 70.72 \\
\hline Dufferin-1 & Clayey Silt Till & 27.38 & 31.20 & 53.06 & 62.03 \\
\hline Dufferin-2 & Clayey Silt Till & 29.95 & 35.18 & 9.56 & 11.70 \\
\hline Laird-1 & Silty Clay & 29.19 & 33.97 & & \\
\hline Laird-2 & Silty Clay & 26.91 & 30.50 & 46.00 & 53.39 \\
\hline Laird-3 & Silty Clay & 27.17 & 30.88 & 18.42 & 21.47 \\
\hline Mount Dennis-1 & Clayey Silt & 23.78 & 26.14 & 8.76 & 9.76 \\
\hline Mount Dennis-2 & Clayey Silt Till & 27.37 & 31.17 & & \\
\hline Mount Dennis-3 & Silty Clay & 27.23 & 30.97 & & \\
\hline Oakwood-1 & Silty Clay & 26.79 & 30.33 & & \\
\hline Oakwood-2 & Clayey Silt Till & 25.10 & 27.94 & 87.51 & 99.05 \\
\hline Oakwood-3 & Silty Clay Till & 28.08 & 32.25 & 24.83 & 29.36 \\
\hline Victoria Park-1 & Clayey Silt Till & 25.56 & 28.57 & 13.64 & 15.53 \\
\hline Victoria Park-2 & Clayey Silt Till & 27.68 & 31.64 & 5.95 & 6.99 \\
\hline Victoria Park-3 & Silty Clay Till & 29.03 & 33.71 & 1.34 & 1.61 \\
\hline West Port-1 & Silty Clay Till & 27.11 & 30.80 & 4.33 & 5.04 \\
\hline West Port-2 & Silty Clay Till & 28.23 & 32.47 & & \\
\hline West Port-3 & Silty Clay & 27.02 & 30.66 & & \\
\hline West Port-4 & Silty Clay Till & 25.41 & 28.36 & 10.81 & 12.28 \\
\hline Wynford-1 & Clayey Silt Till & 23.52 & 25.80 & 40.01 & 44.44 \\
\hline Wynford-2 & Silty Clay & 20.62 & 22.10 & 23.69 & 25.57 \\
\hline Wynford-3 & Silty Clay Till & 28.67 & 33.14 & & \\
\hline Chaplin-1 & Clay & 20.23 & 21.63 & & \\
\hline Chaplin-2 & Silty Clay & 22.79 & 24.84 & & \\
\hline Chaplin-3 & Silty Clay & 23.50 & 25.90 & & \\
\hline Chaplin-4 & Silty Clay & 22.77 & 24.82 & & \\
\hline Chaplin-5 & Silty Clay & 15.29 & 15.86 & 31.22 & 32.46 \\
\hline Chaplin-6 & Silty Clay & 23.81 & 26.19 & & \\
\hline Chaplin-7 & Clay & 21.53 & 23.23 & & \\
\hline \multirow[t]{5}{*}{ Chaplin-8 } & Silty Clay & 21.21 & 22.83 & 32.85 & 35.64 \\
\hline & St. Deviation & 3.47 & 4.75 & 21.48 & 24.21 \\
\hline & Max & 30.61 & 36.28 & 87.51 & 99.05 \\
\hline & Min & 15.29 & 15.86 & 1.34 & 1.61 \\
\hline & Mean & 25.62 & 28.90 & 21.57 & 24.35 \\
\hline
\end{tabular}

In table 4-2 and 4-3, some of values are not presented because their values are not correlated or their root mean square value is too low. The friction angle $(\phi ')$ derived using the maximum deviator 
stress and the maximum stress ratio shows below in histogram plot (Figure 4-3). In both cases the values are normally distributed. But in case of friction angle $(\psi)$ they are not normally distributed.
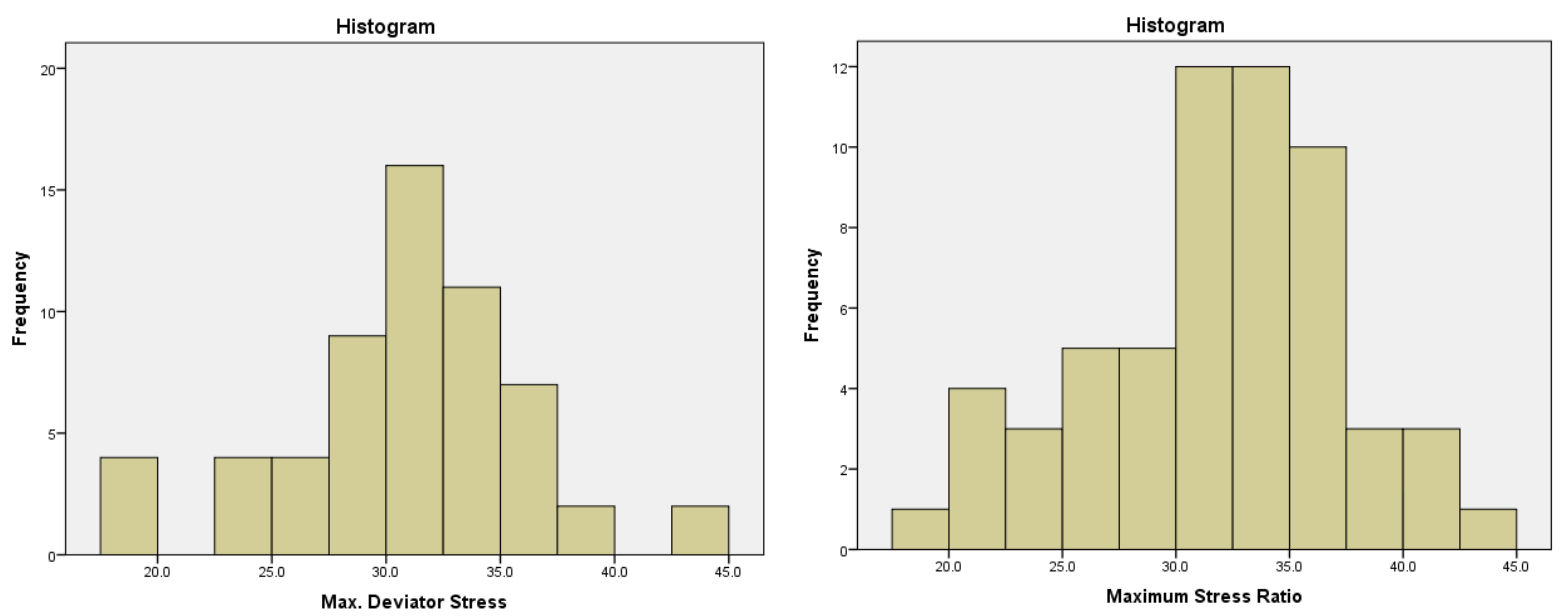

Figure 4-3 Histogram plot of friction angle ( $\left.\phi^{\prime}\right)$ based on maximum deviator stress and the maximum stress ratio

The different values of friction angle and effective friction angle of the soil are listed in table 4-4. The statistical values for mean, median, standard deviation, minimum and maximum friction angle values are presented. The mean friction angle calculated using of maximum stress ratio and the maximum deviator stress are close to each other.

Table 4-4 Descriptive statistics of friction angle and effective friction angle on different failure criteria

\begin{tabular}{|l|c|l|c|c|c|c|}
\hline & \multicolumn{2}{|c|}{ Max. Stress Ratio } & \multicolumn{2}{c|}{ Max. Deviator Stress } & \multicolumn{2}{c|}{ Residual Stress } \\
\hline Description & $\begin{array}{l}\text { Friction } \\
\text { Angle }(\psi) \\
\text { degrees }\end{array}$ & $\begin{array}{l}\text { Friction } \\
\text { Angle }\left(\phi^{\prime}\right) \\
\text { degrees }\end{array}$ & $\begin{array}{l}\text { Friction } \\
\text { Angle }(\psi) \\
\text { degrees }\end{array}$ & $\begin{array}{l}\text { Friction } \\
\text { Angle }(\phi ') \\
\text { degrees }\end{array}$ & $\begin{array}{l}\text { Friction } \\
\text { Angle }(\psi) \\
\text { degrees }\end{array}$ & $\begin{array}{l}\text { Friction } \\
\text { Angle }\left(\phi^{\prime}\right) \\
\text { degrees }\end{array}$ \\
\hline Mean & 27.53 & 31.76 & 26.96 & 30.87 & 25.63 & 28.90 \\
\hline Median & 28.27 & 32.53 & 27.46 & 31.32 & 26.91 & 30.50 \\
\hline Standard Deviation & 3.81 & 5.59 & 3.58 & 5.13 & 3.47 & 4.75 \\
\hline Sample Variance & 14.54 & 31.28 & 12.81 & 26.36 & 12.04 & 22.53 \\
\hline Range & 16.66 & 25.33 & 16.21 & 23.91 & 15.33 & 20.42 \\
\hline Minimum & 18.60 & 19.66 & 18.05 & 19.02 & 15.29 & 15.86 \\
\hline Maximum & 35.26 & 44.99 & 34.26 & 42.93 & 30.61 & 36.28 \\
Number of sample & 59 & 59 & 59 & 59 & 59 & 59 \\
\hline
\end{tabular}




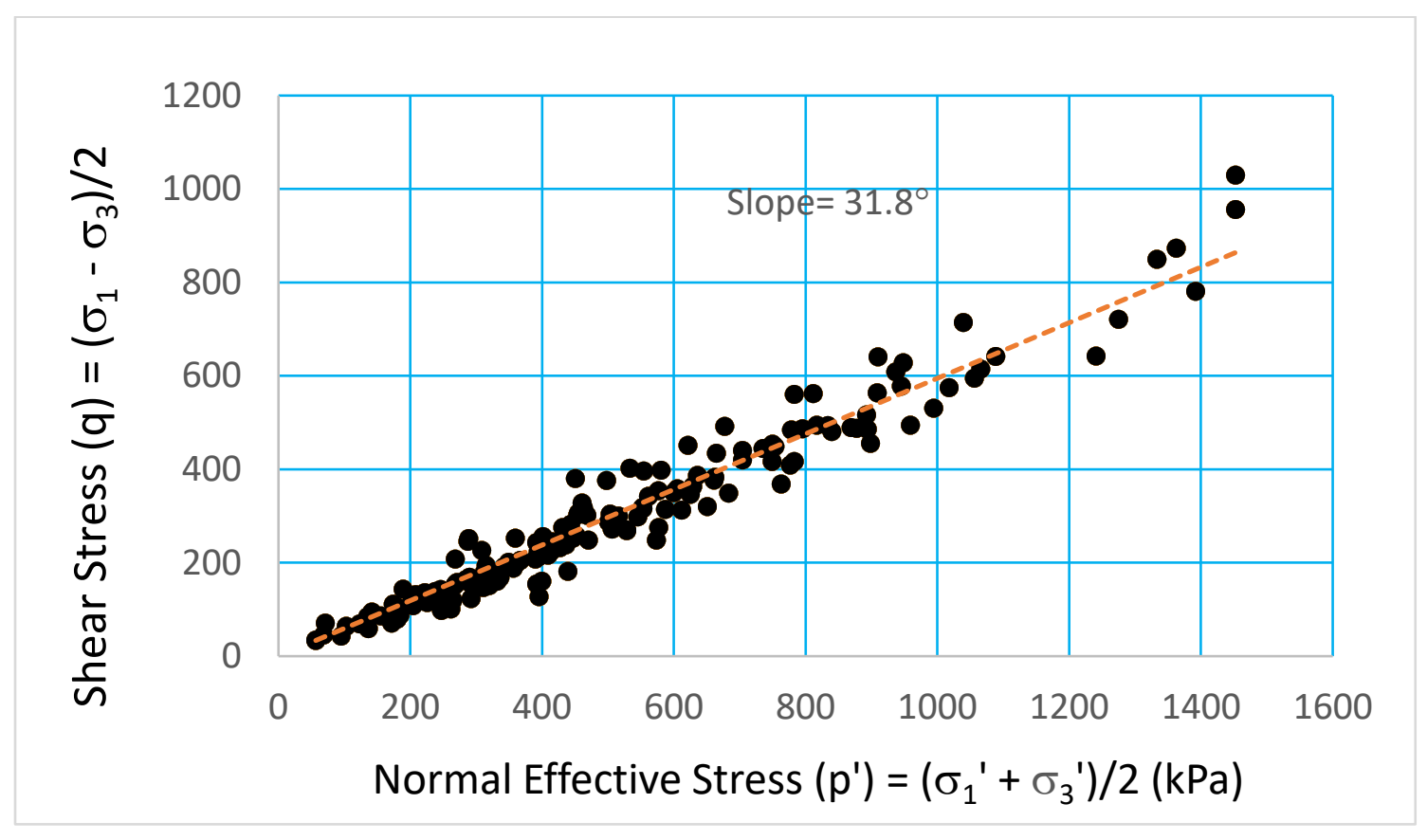

Figure 4-4 Relation between shear stress and normal effective stress at max. stress ratio

While plotting the normal effective stress and shear stress at maximum stress ratio, it gives the trend line having inclination of 31.8 degree (Figure 4-4). The lowest angle is 18.6 degrees and the highest is 41.1 degrees. There is some scatter in data at higher confining pressure, however, the deviator stress also increases proportionally.

There is outlier data point at the top which ultimately effect on the $\mathrm{R}^{2}$ value and data more close to each other if we remove the outlier. The outlier is calculated in Excel by calculating Quartile1, Quartile3, Interquartile, Upperbound and Lowerbound from data. The Upper bound (Quartile3 + $1.5 *$ Interquartile) and lower bound (Quartile $1-1.5 *$ Interquartile) are calculated. Then using False $=\mathrm{OR}(\mathrm{x}>$ Upperbound, $\mathrm{x}<$ Lowerbound $)$ to get the data comes under the range or not. If we get true then that is consider as outlier and from calculation there are 6 data points at the top upper right comes as the outlier in figure $4-4$.

For the same data set t-stat test was also carried out to check the distribution were normal or not, or the null hypothesis is accepted or rejected (Table 4-5). Here we can see the p-value have more 
than 0.0287 that means it can said rejected the null hypothesis by $97 \%$ confidence and it also reject the null intercept value and must be zero.

Table 4-5 Calculation of t-stat and other variables from regression analysis using Excel

\begin{tabular}{|l|r|r|r|r|r|r|}
\hline & Coefficients & Standard Error & \multicolumn{1}{c|}{$t$ Stat } & \multicolumn{1}{c|}{ P-value } & $\begin{array}{c}\text { Lower } \\
95 \%\end{array}$ & $\begin{array}{c}\text { Upper } \\
95 \%\end{array}$ \\
\hline Intercept & -13.544 & 6.1419 & -2.205 & 0.028 & -25.668 & -1.422 \\
\hline X Variable 1 & 0.615 & 0.010 & 58.586 & $1.5 \mathrm{E}-115$ & 0.594 & 0.635 \\
\hline
\end{tabular}

The standard error of the estimate can use to measure the accuracy of regression line in terms of prediction. The regression line minimizes the sum of squared deviations of prediction. It can be defined as

$E_{\text {est }}=\sqrt{\frac{\sum(Y-\bar{Y})^{2}}{N-2}}$

where $E_{\text {est }}$ is standard error of the estimate, $\mathrm{Y}$ is actual score and $\overline{\mathrm{Y}}$ is predicted score and $\mathrm{N}$ is the number of data.

From the calculation of estimated standard error for figure 4-4, it is computed that the mean was higher than that of the estimated error, which means the data for the linear regression was closer than from the mean average line. While plotting the error, the graph shows only random distribution, no any normal distribution. The error calculated was 47.34.

The equation 4-1 was also used to calculate the estimated standard error for data of figure 4-5 and was computed as 43.67 which was lower than that of mean value. This means the data for the linear regression is closer than that from the mean average line. The plotting of the error in histogram does not show any normal distribution. 


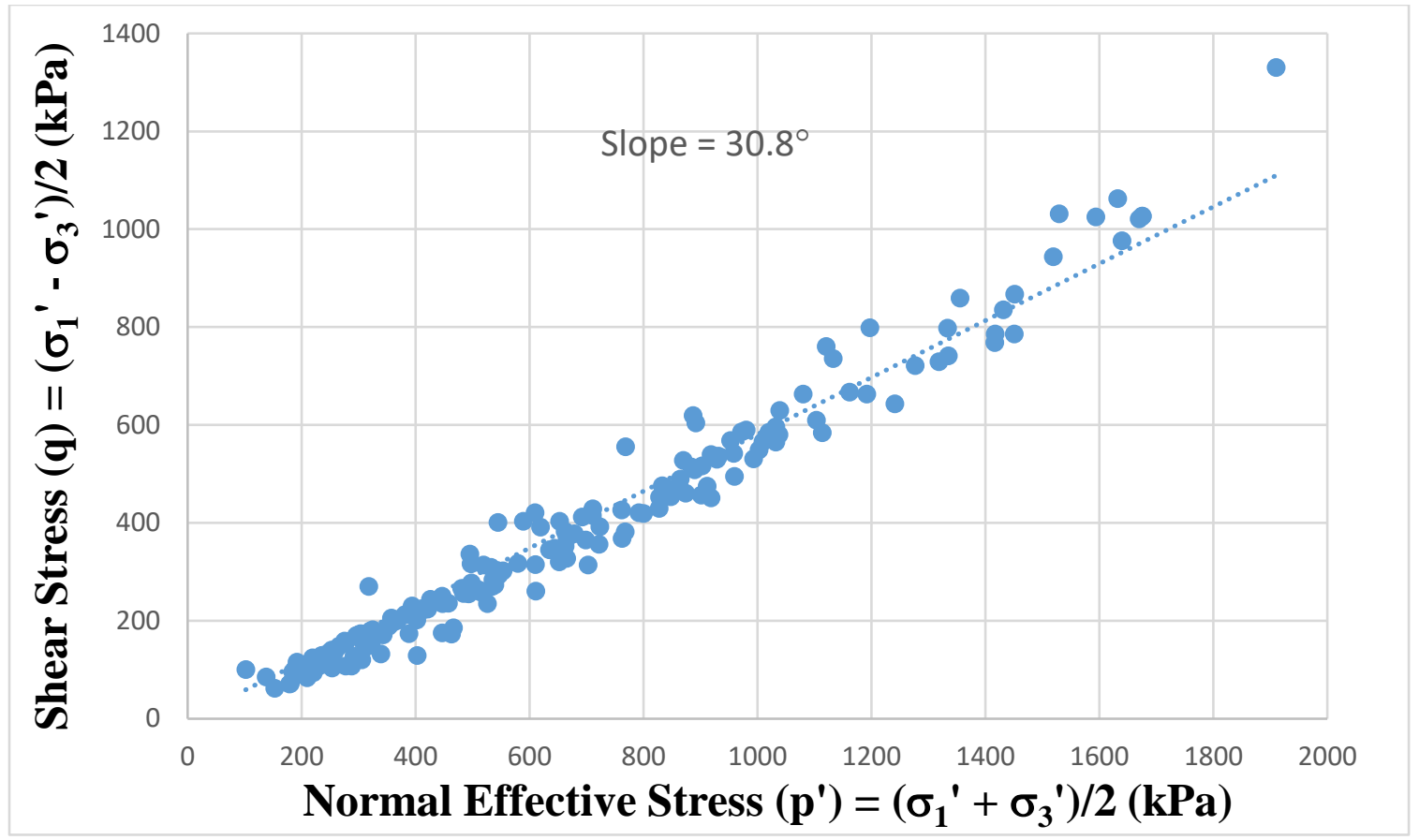

Figure 4-5 Relation between shear stress and normal effective stress at max. deviator stress

If we plot the shear stress and the normal effective stress of all soil types in terms of the maximum deviator stress then the average linear relations is about 30.15 degree and the root mean square is 0.96 which means the data are more close to each other (Figure 4-5). In this figure there is only one data belongs to an outlier and if we remove the outlier value from the plot our $\mathrm{R}^{2}$ value will increases.

\subsubsection{Soil Type and Stress Path}

The friction angle of sandy soil in a constant effective stress produces a curved failure envelop (Lee and Seed, 1967). There are all together five different types of soil and their average angle of shear failure are described separately.

While defining the peak stress difference for the OC specimens, the failure envelops deviated from $\mathrm{NC}$, but the deviation will no longer seen in case of picking the peak effective principal stress ratio. Murthy et al. (1981) conducted undrained compression tests on remolded kaolinite specimens that were isotropically consolidated at different OCR's (1 to 32). The results showed that the failure envelopes defined by the peak principal stress difference and the peak effective principal stress 
ratio lie very closely with each other in the q-p' plane regardless of stress history, where $q=\left(\sigma_{1}\right.$ $\left.\sigma_{3}\right) / 2$ and $p^{\prime}=\left(\sigma_{1}{ }^{\prime}+\sigma_{3}{ }^{\prime}\right) / 2$.

The stress path is calculated based on the highest stress ratio, their corresponding values of shear stress (q), and normal effective stress (p'). All shear and normal effective stresses are plotted (Figure 4-6 to 4-10) based on the maximum stress ratio and maximum deviator stresses for each soil types. There are five different soil types namely Silty Clay, Clayey Silt, Clay, Silty Clay Till, Clayey Silt Till and plotting of shear stress versus normal stresses are describes below (Figure 46 to $4-10)$.

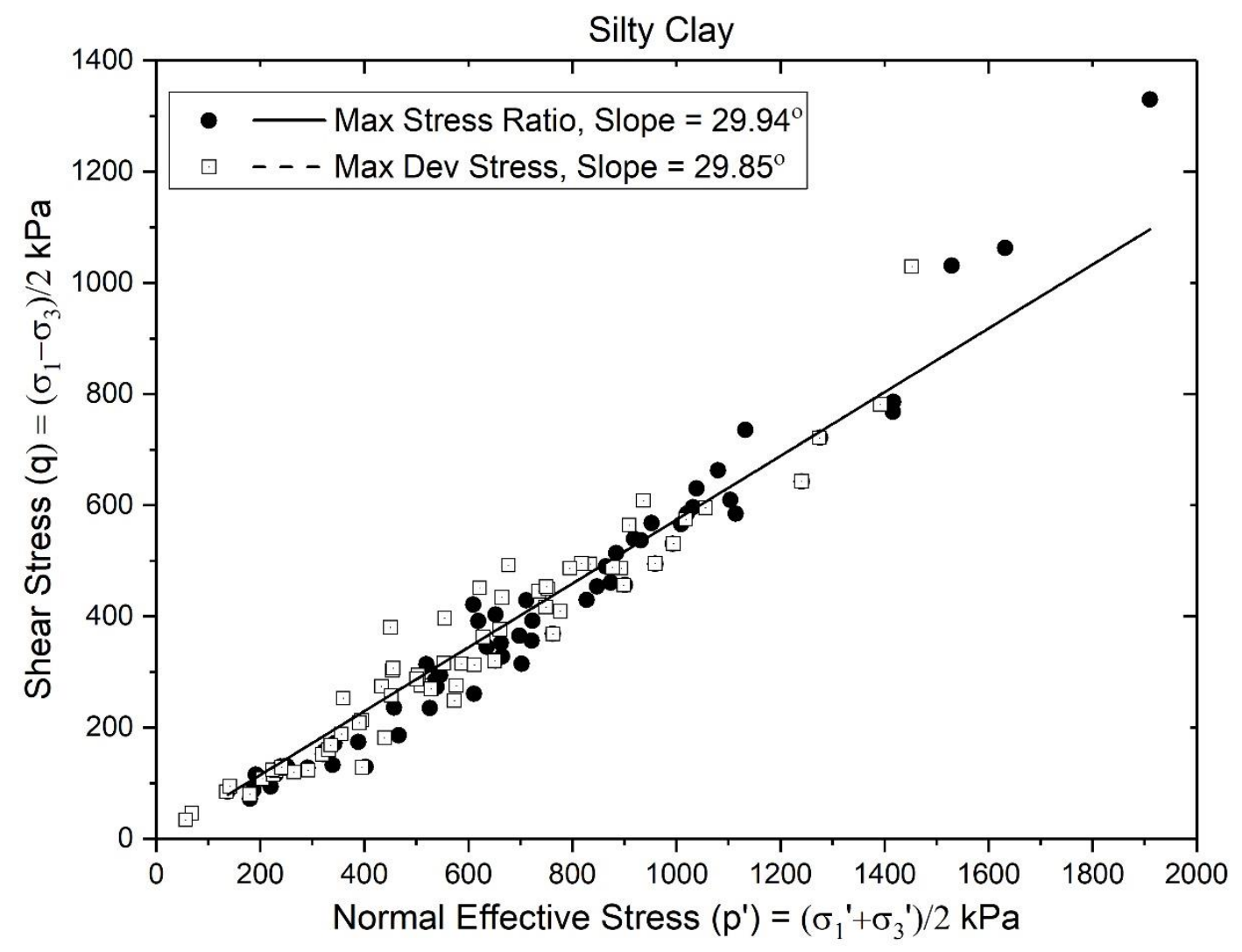

Figure 4-6 Relation between the shear stress and normal effective stress of Silty Clay

The plot of shear stress and the normal effective stress of Silty Clay shows that the slope of average linear line is about 29.94 degrees in terms of the maximum stress ratio and 29.85 degrees in terms of the maximum deviator stress. The value on maximum stress ratio is slightly higher than maximum deviator stress (Figure 4-6). 


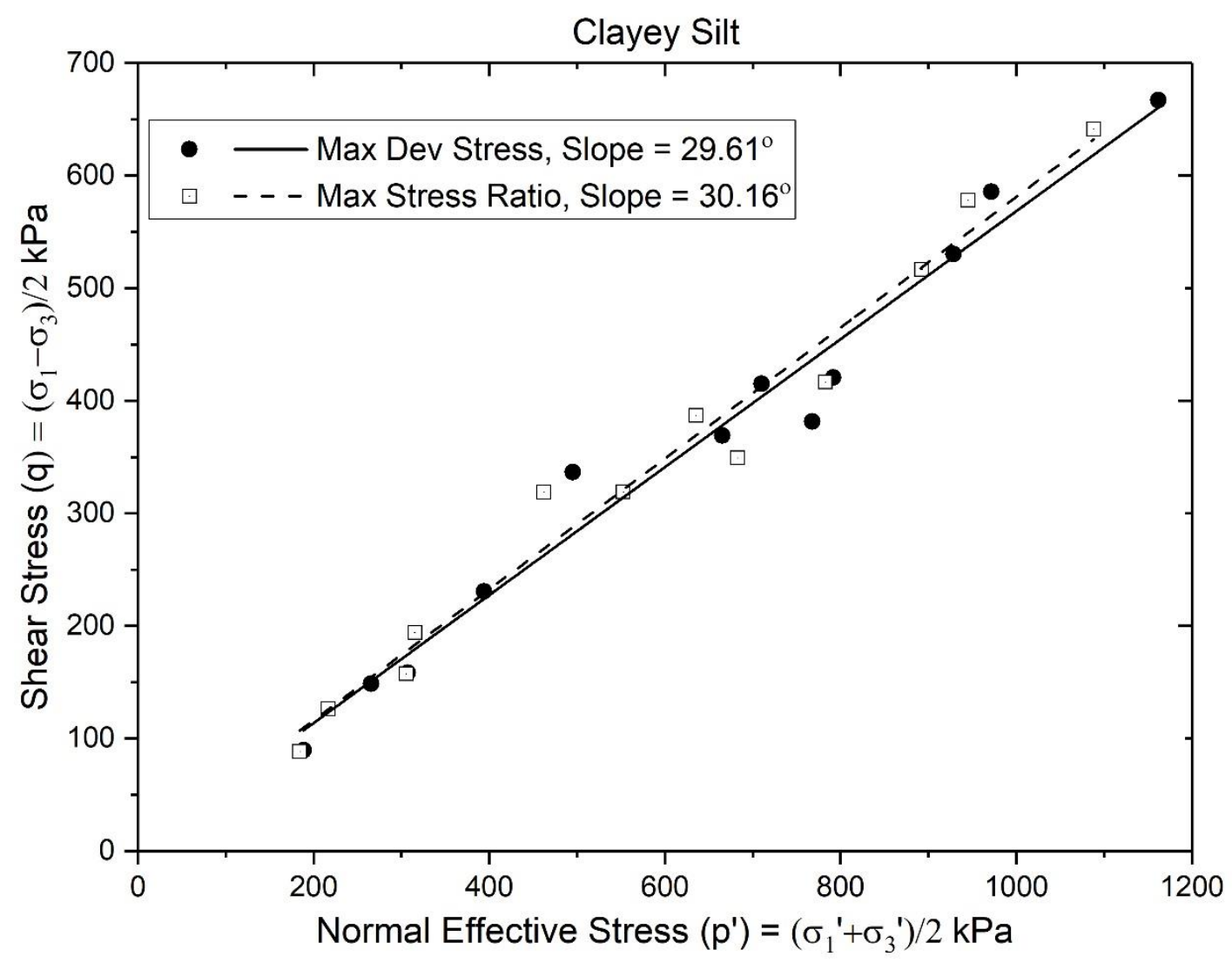

Figure 4-7 Relation between the shear stress and normal effective stress of Clayey Silt

The Clayey Silt found in the area have also similar linear relations while plotting shear stress against normal effective stress. The best fitted line shows the slope angle of 30.16 degrees on the maximum stress ratio and 29.61 degree on maximum deviator stress. The value on maximum stress ratio is higher than that of the maximum deviator stress (Figure 4-7). 


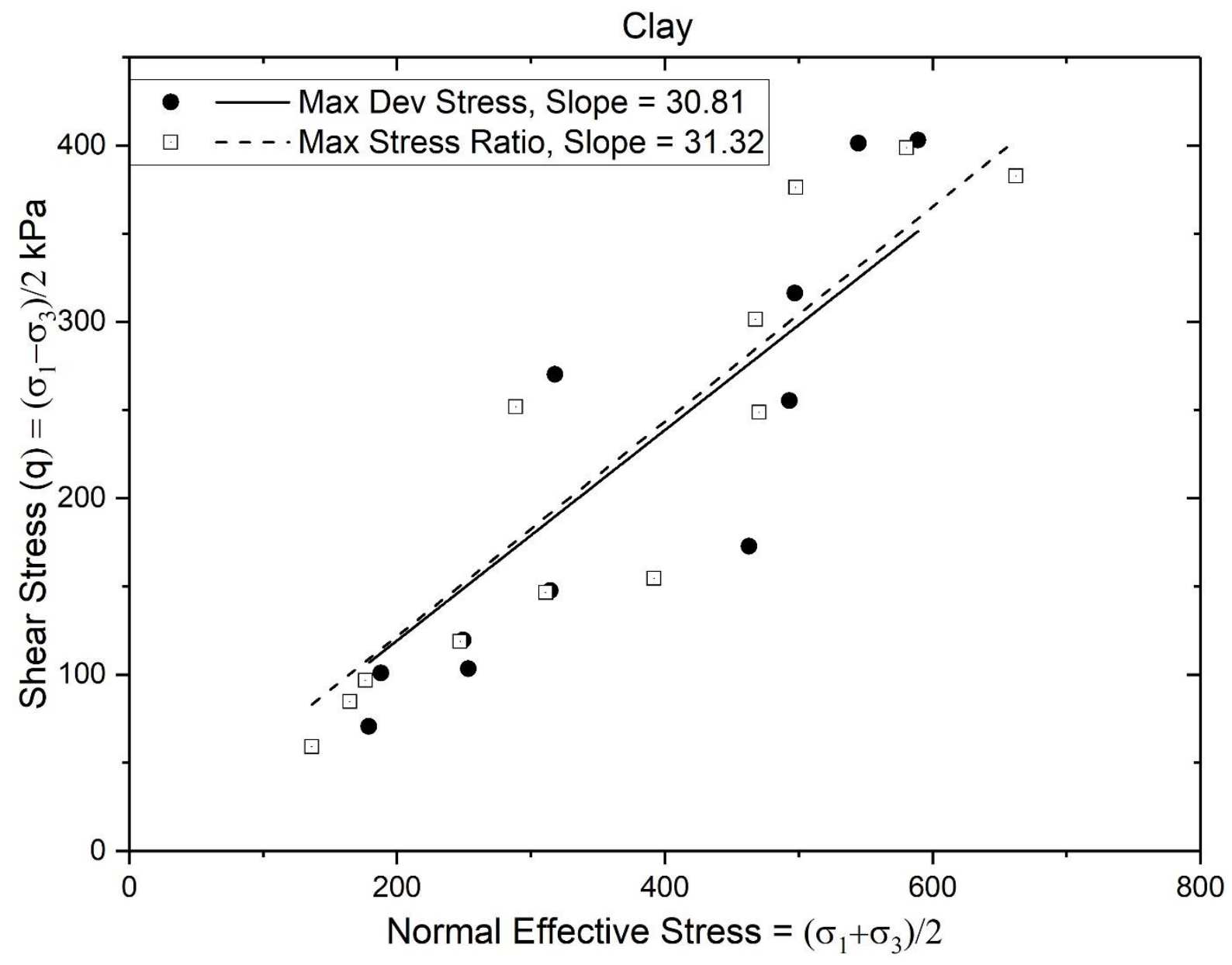

Figure 4-8 Relation between the shear stress and normal effective stress of Clay

The Clay soil is different from other soil types and there are more scatter in values. The best fitted line shows the linear relationships having slope angle of 31.32 degree on maximum stress ratio and 30.81 on maximum deviator stress. The slope angle value based on the maximum stress ratio is higher than that from the maximum deviator stress method (Figure 4-8). 


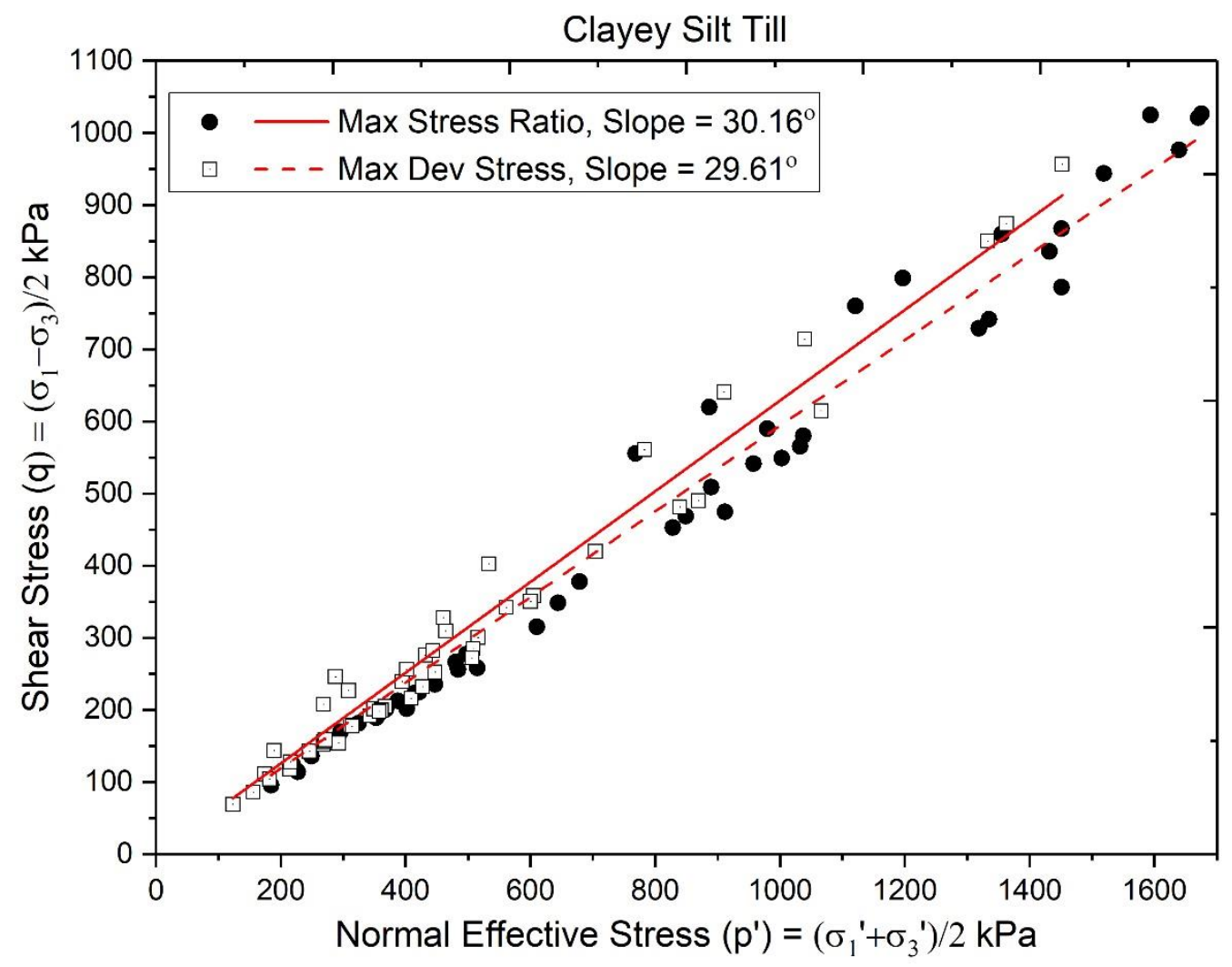

Figure 4-9 Relation between the shear stress and normal effective stress of Clayey Silt Till

The another soil type is Clayey Silt Till and the normal effective stress and shear stress plot shows more similarity to the best fitted line having a slope about 30.16 degrees on the maximum stress ratio and 29.61 degrees when plotted the maximum deviator stresses. The best fitted line slope on the maximum stress ratio is higher than plot of the maximum deviator stress (Figure 4-9). 


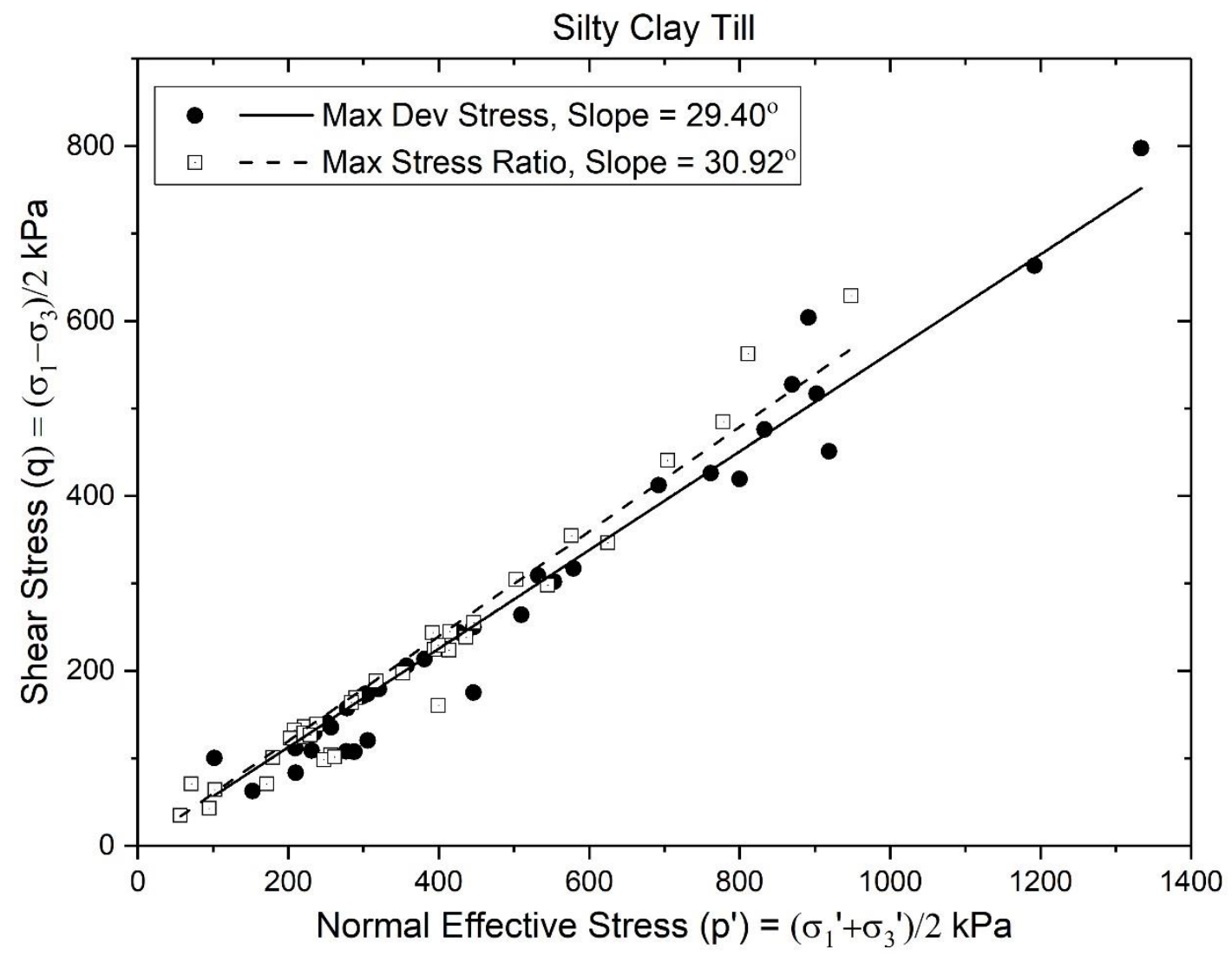

Figure 4-10 Relation between the shear stress and normal effective stress of Silty Clay Till

The plotting of soil type Silty Clay Till have little bit scatter data. The slope of trend line is about 30.92 degrees on the maximum stress ratio whereas the slope of trend line on the maximum deviator stress is 29.40 degrees (Figure 4-10).

The failure criteria based on the maximum deviator stress and the maximum stress ratio have some similar relations on each soil types. The slope of the trend line on maximum stress ratio is always higher slope angle of trend line over maximum deviator stress (Figure 4-11). 


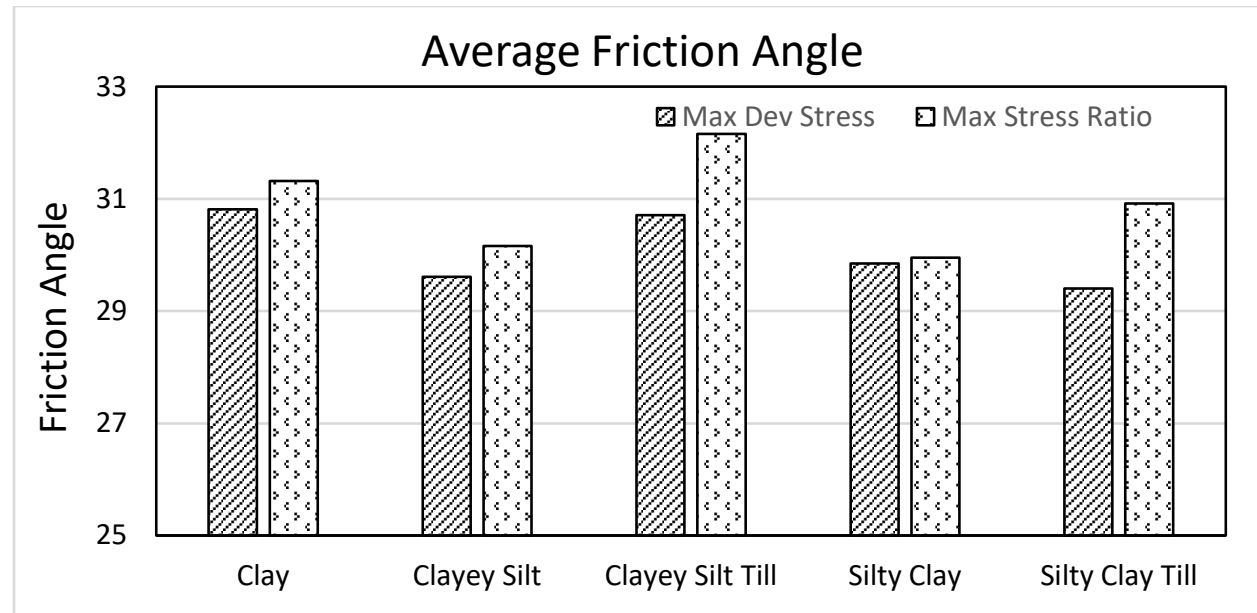

Figure 4-11 Comparison of the shear stress and normal effective stress based on maximum deviator stress and maximum stress ratio

\subsubsection{Soil Depth and Shear Angle}

There are many core samples collected during the construction of LRT. The depth of the soil sampling ranges as shallow as $3 \mathrm{~m}$ to as deep as $40 \mathrm{~m}$ below the ground level. During the triaxial test the soil samples were sheared while applying the deviator stress. The angle of shear failure determination is based on the applied stresses (vertical and horizontal). The shear values ranges from 18.6 to 35.2 degrees with average is about 27.5 degrees. The variation of shear angle is also dependent on the soil type.

It is assumed that the shear angle increases with the increase in depth. But in case of the fine grained tills of GTA, no such relationship was obtained from the triaxial test data. The reason for this is due to the fact that the sample depth is relatively small compared to its preconsolidation pressure.

\subsubsection{Soil Type and Friction Angle}

The friction angles are calculated based on the value of shear stress and the normal effective stress at the highest stress ratio $\left(\sigma_{1}{ }^{\prime} / \sigma_{3}{ }^{\prime}\right)$. The values ranges from 18.6 to 35.2 and also differs in each soil type (Figure 4-12).

Clayey Silt has a low variation in the friction angle which ranges from 25.4 to 30.2 degrees with the median value of 27.5 degrees. Silty Clay have a large variation from 18.6 to 33.5 degrees 
whereas the median value is 27 degrees. The corresponding values for different types of finegrained tills in the GTA are listed in Table 4-6.

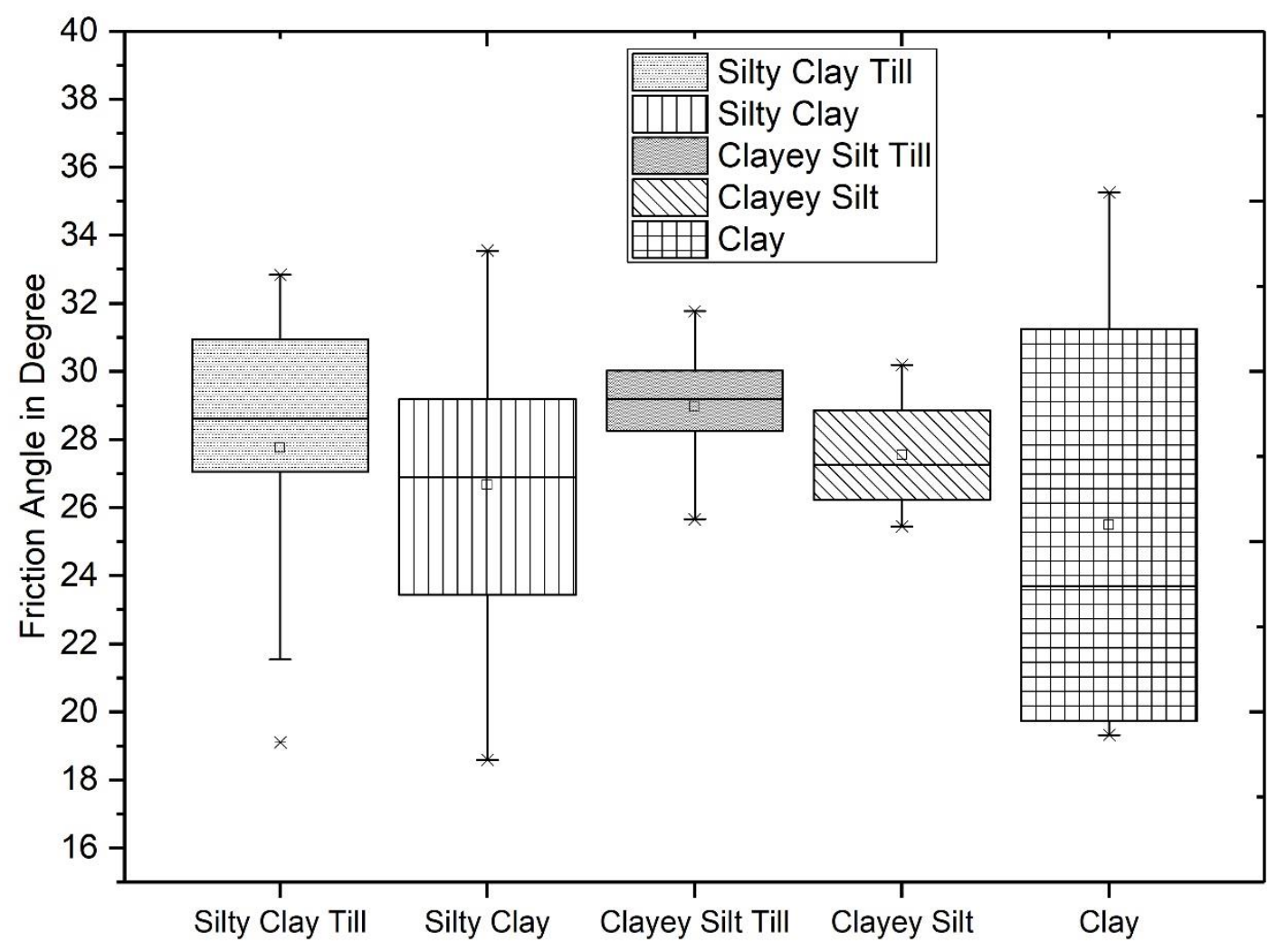

Figure 4-12 Soil type and friction angle relation

The figure 4-12 shows the variation in the data. The lower point indicates lowest value and the upper point is highest value, if we consider the friction angle of Silty Clay Till the lower value is 19.1 and the highest value is 32.8 degrees. The box completely short in case of Clayey Silt Till indicates that the overall friction angle have high degree of agreement but in case of Clay the box is much higher that means there is wide variation in friction angle. The lower level of box is the first quartile and the upper level is 3rd quartile. The line at the middle of box represents median of the data. The point inside the box represents the mean value. The horizontal width of the box has no any meanings. The statistical description of the soil are presented below in table 4-6. 
Table 4-6 The statistical description of different soil types

\begin{tabular}{|c|c|c|c|c|c|c|c|c|c|c|}
\hline Soil Type & \multicolumn{2}{|c|}{ Clay } & \multicolumn{2}{|c|}{ Clayey Silt } & \multicolumn{2}{|c|}{ Clayey Silt Till } & \multicolumn{2}{|c|}{ Silty Clay } & \multicolumn{2}{|c|}{ Silty Clay Till } \\
\hline Description & $\begin{array}{l}\text { Friction } \\
\text { Angle } \\
(\psi) \\
\text { degrees }\end{array}$ & $\begin{array}{c}\text { Friction } \\
\text { Angle } \\
\left(\phi^{\prime}\right) \\
\text { degrees }\end{array}$ & $\begin{array}{c}\text { Friction } \\
\text { Angle } \\
(\psi) \\
\text { degrees }\end{array}$ & $\begin{array}{c}\text { Friction } \\
\text { Angle } \\
\left(\phi^{\prime}\right) \\
\text { degrees }\end{array}$ & $\begin{array}{c}\text { Friction } \\
\text { Angle } \\
(\psi) \\
\text { degrees }\end{array}$ & $\begin{array}{c}\text { Friction } \\
\text { Angle } \\
\left(\phi^{\prime}\right) \\
\text { degrees }\end{array}$ & $\begin{array}{c}\text { Friction } \\
\text { Angle } \\
(\psi) \\
\text { degrees }\end{array}$ & $\begin{array}{c}\text { Friction } \\
\text { Angle } \\
\left(\phi^{\prime}\right) \\
\text { degrees }\end{array}$ & $\begin{array}{c}\text { Friction } \\
\text { Angle } \\
(\psi) \\
\text { degrees }\end{array}$ & $\begin{array}{c}\text { Friction } \\
\text { Angle } \\
\left(\phi^{\prime}\right) \\
\text { degrees }\end{array}$ \\
\hline Mean & 25.49 & 31.62 & 27.55 & 33.00 & 28.98 & 31.32 & 26.67 & 31.68 & 27.75 & 30.00 \\
\hline Median & 23.69 & 32.68 & 27.27 & 32.89 & 29.20 & 31.28 & 26.90 & 33.24 & 28.61 & 30.48 \\
\hline Standard Dev. & 7.42 & 6.80 & 1.97 & 0.70 & 1.57 & 8.96 & 3.93 & 4.59 & 4.47 & 7.69 \\
\hline Range & 15.93 & 15.92 & 4.75 & 1.67 & 6.11 & 11.02 & 14.96 & 15.53 & 13.74 & 25.33 \\
\hline Minimum & 19.33 & 22.61 & 25.45 & 32.27 & 25.66 & 30.53 & 18.60 & 21.52 & 19.11 & 19.66 \\
\hline Maximum & 35.26 & 38.53 & 30.20 & 33.94 & 31.77 & 41.55 & 33.56 & 37.05 & 32.84 & 44.99 \\
\hline
\end{tabular}

\subsubsection{Shear Bands}

Shear bands were observed in most of the tests. Sometimes they were extended only about halfway and sometimes the samples were failed as a bulge failure without forming a shear band. Samples with high clay contents are more likely show the bulging failure mode. The development of the shear band in triaxial test of clay sample has not been reported (Ramanatha Iyer, 1975; Georgiannou and Burland, 2001). The clear shear bands are observed in most sandy soil specimens. The surface mostly irregular (not a planner) but some are shown in almost planner surface. These shear planes are found in different inclinations having wide range among different tests. Photographs in Figure 4-13 show that the shear bands propagate to different direction and have some relation with the soil layering or the weakest direction or sometimes follow the drainage direction. 


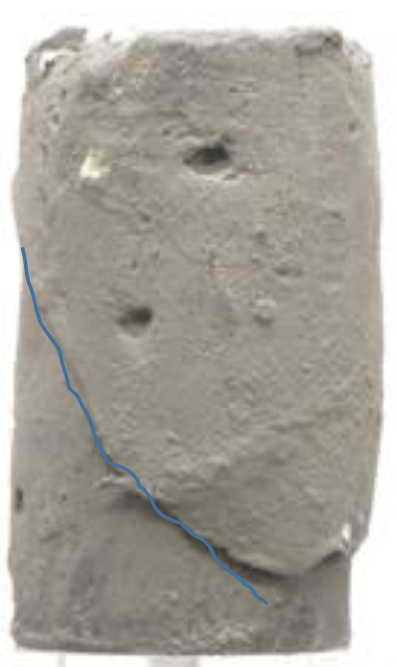

$\operatorname{SC} 4 \mathrm{~B} / 4 \mathrm{~A}-1$

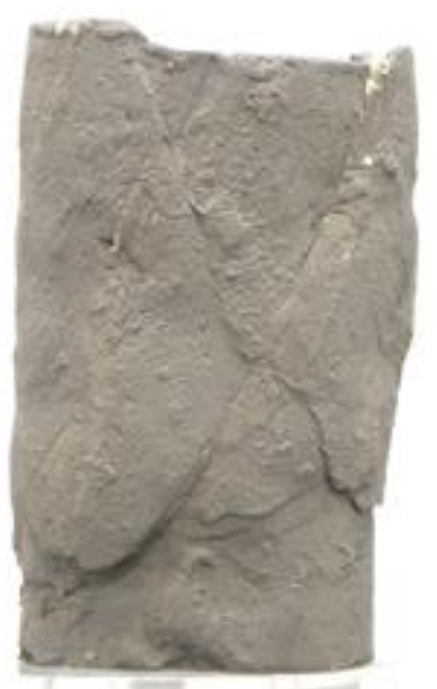

$\mathrm{SC} 4 \mathrm{~B} / 4 \mathrm{~A}-2$

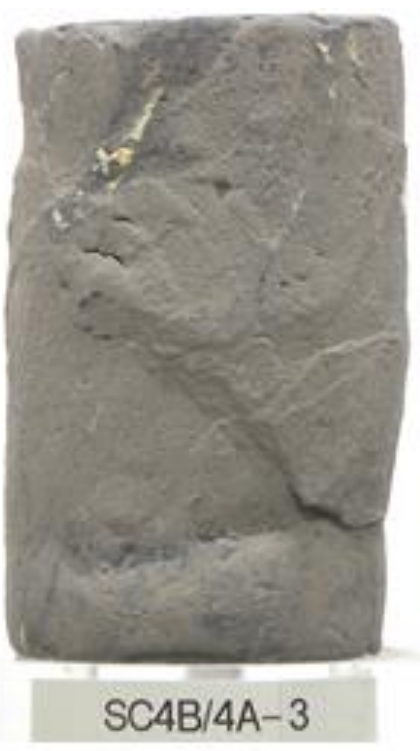

SC4B/4A-3

Figure 4-13 The triaxial test result showing different angle of failure in Allen station ( SPL, 2013)

\subsubsection{Undrained Shear Modulus (Eu)}

The undrained shear modulus can estimated with the stress ratio and the strain during shearing. It can estimate in laboratory tests directly by triaxial test and indirectly by Oedometer test.

The strain response by the soil sample depends on the soil characteristics. The undrained shear modulus is calculated using the secant modulus method. In this study, two points at the $1 / 3$ and $2 / 3$ peak stress values are used to calculate the secant modulus. For the calculation of undrained shear modulus the value of strain at the 50 percentile of deviator stresses are taken. Table 4-7 shows the undrained shear moduli of fine-grained soils in the GTA. There is wide variation in the undrained shear modulus in different types of soil and are presented below (Figure 4-14). The calculated maximum and minimum undrained shear moduli are $167059.2 \mathrm{kPa}$ and $1526.02 \mathrm{kPa}$ respectively. The undrained Modulus of all soil type is presented in Table 4-7below. 
Table 4-7 Undrained shear modulus of different soils $(\mathrm{kPa})$

\begin{tabular}{|c|c|c|c|c|c|}
\hline Soil type & $\begin{array}{l}\text { Undrained } \\
\text { Modulus } \\
(\mathrm{kPa})\end{array}$ & Soil type & $\begin{array}{l}\text { Undrained } \\
\text { Modulus } \\
(\mathrm{kPa})\end{array}$ & Soil type & $\begin{array}{l}\text { Undrained } \\
\text { Modulus } \\
(\mathrm{kPa})\end{array}$ \\
\hline Clay & 41783.97 & Clayey Silt Till & 10401.36 & Silty Clay & 38714.37 \\
\hline Clay & 70426.80 & Clayey Silt Till & 26863.31 & Silty Clay & 18049.05 \\
\hline Clay & 107905.56 & Clayey Silt Till & 11319.28 & Silty Clay & 14288.68 \\
\hline Clay & 61289.13 & Clayey Silt Till & 49739.03 & Silty Clay & 19393.20 \\
\hline Clay & 63206.99 & Clayey Silt Till & 20872.99 & Silty Clay & 5227.63 \\
\hline Clay & 119544.90 & Clayey Silt Till & 9044.02 & Silty Clay & 8758.41 \\
\hline Clay & 10902.95 & Clayey Silt Till & 15649.58 & Silty Clay & 30896.64 \\
\hline Clay & 18594.46 & Clayey Silt Till & 17713.30 & Silty Clay & 28438.34 \\
\hline Clay & 38522.45 & Clayey Silt Till & 10448.16 & Silty Clay & 31070.02 \\
\hline Clay & 11175.47 & Clayey Silt Till & 14794.86 & Silty Clay & 39912.62 \\
\hline Clay & 13577.96 & Clayey Silt Till & 27649.89 & Silty Clay & 22981.53 \\
\hline Clay & 21032.49 & Clayey Silt Till & 3369.53 & Silty Clay & 17760.90 \\
\hline Clayey Silt & 2982.74 & Clayey Silt Till & 3553.71 & Silty Clay & 33801.37 \\
\hline Clayey Silt & 41314.20 & Clayey Silt Till & 6390.84 & Silty Clay & 74947.62 \\
\hline Clayey Silt & 75209.61 & Silty Clay & 46004.75 & Silty Clay & 149051.44 \\
\hline Clayey Silt & 15944.15 & Silty Clay & 81434.85 & Silty Clay & 100309.50 \\
\hline Clayey Silt & 33162.83 & Silty Clay & 77781.13 & Silty clay & 130500.09 \\
\hline Clayey Silt & 40382.06 & Silty clay & 48621.53 & Silty clay & 60935.46 \\
\hline Clayey Silt & 76078.36 & Silty clay & 102426.64 & Silty clay & 77003.02 \\
\hline Clayey Silt & 97643.34 & Silty clay & 108343.10 & Silty clay & 62668.45 \\
\hline Clayey Silt & 324834.20 & Silty Clay & 19675.77 & Silty clay & 50657.83 \\
\hline Clayey Silt & 8453.66 & Silty Clay & 13891.00 & Silty clay & 113411.17 \\
\hline Clayey Silt & 61076.83 & Silty Clay & 21724.27 & Silty Clay Till & 20624.74 \\
\hline Clayey Silt & 8113.44 & Silty Clay & 32933.64 & Silty Clay Till & 137829.86 \\
\hline Clayey Silt till & 10109.15 & Silty Clay & 38206.00 & Silty Clay Till & 167059.24 \\
\hline Clayey Silt till & 19894.93 & Silty Clay & 50334.96 & Silty Clay Till & 28641.72 \\
\hline Clayey Silt till & 30876.83 & Silty Clay & 3548.09 & Silty Clay Till & 17659.10 \\
\hline Clayey Silt till & 40767.50 & Silty Clay & 36052.18 & Silty Clay Till & 33577.03 \\
\hline Clayey Silt till & 120297.00 & Silty Clay & 42480.48 & Silty Clay Till & 14060.86 \\
\hline Clayey Silt till & 28389.72 & Silty Clay & 3316.07 & Silty Clay Till & 21217.56 \\
\hline Clayey Silt till & 28078.86 & Silty Clay & 26303.90 & Silty Clay Till & 24499.49 \\
\hline Clayey Silt till & 68602.39 & Silty Clay & 2102.35 & Silty Clay Till & 3979.98 \\
\hline Clayey Silt till & 11110.84 & Silty Clay & 56611.39 & Silty Clay Till & 8196.56 \\
\hline Clayey Silt till & 40663.03 & Silty Clay & 57721.42 & Silty Clay Till & 10832.43 \\
\hline Clayey Silt till & 48496.73 & Silty Clay & 64053.54 & Silty Clay Till & 3598.27 \\
\hline Clayey Silt till & 12778.02 & Silty Clay & 19696.35 & Silty Clay Till & 7380.58 \\
\hline Clayey Silt Till & 1526.03 & Silty Clay & 61479.46 & Silty Clay Till & 13102.47 \\
\hline
\end{tabular}




\begin{tabular}{|l|l|l|l|l|l|} 
Clayey Silt Till & 4622.62 & Silty Clay & 47927.87 & Silty Clay Till & 1616.30 \\
\hline Clayey Silt Till & 5677.95 & Silty Clay & 48203.17 & Silty Clay Till & 21800.65 \\
\hline Clayey Silt Till & 4907.73 & Silty Clay & 50140.00 & Silty Clay Till & 43877.33 \\
\hline Clayey Silt Till & 10751.05 & Silty Clay & 45278.26 & Silty Clay Till & 5744.34 \\
\hline Clayey Silt Till & 13020.11 & Silty Clay & 3852.17 & Silty Clay Till & 14002.31 \\
\hline Clayey Silt Till & 3572.64 & Silty Clay & 7303.82 & Silty Clay Till & 62644.01 \\
\hline Clayey Silt Till & 4585.24 & Silty Clay & 9889.48 & Silty Clay Till & 4866.59 \\
\hline Clayey Silt Till & 7689.63 & Silty Clay & 39194.11 & Silty Clay Till & 6470.40 \\
\hline Clayey Silt Till & 8720.56 & Silty Clay & 25267.15 & Silty Clay Till & 7068.05 \\
\hline Clayey Silt Till & 19409.05 & Silty Clay & 65680.34 & Silty Clay Till & 3333.62 \\
\hline Clayey Silt Till & 11385.09 & Silty Clay & 5421.70 & Silty Clay Till & 10973.44 \\
\hline Clayey Silt Till & 6667.38 & Silty Clay & 8449.93 & Silty Clay Till & 8679.47 \\
\hline Clayey Silt Till & 17857.88 & Silty Clay & 4925.59 & Silty Clay Till & 2913.83 \\
\hline Clayey Silt Till & 24910.32 & Silty Clay & 2243.29 & Silty Clay Till & 6539.69 \\
\hline Clayey Silt Till & 57445.77 & Silty Clay & 9058.47 & Silty Clay Till & 18063.92 \\
\hline Clayey Silt Till & 83977.52 & Silty Clay & 10626.23 & Silty Clay Till & 7828.31 \\
\hline Clayey Silt Till & 158152.18 & Silty Clay & 21959.56 & Silty Clay Till & 41133.78 \\
\hline Clayey Silt Till & 31199.55 & Silty Clay & 21012.88 & Silty Clay Till & 20507.96 \\
\hline Clayey Silt Till & 54964.28 & Silty Clay & 43301.75 & Silty Clay Till & 4280.75 \\
\hline Clayey Silt Till & 87677.56 & Silty Clay & 21912.63 & Silty Clay Till & 10300.69 \\
\hline Clayey Silt Till & 7580.84 & Silty Clay & 20003.74 & Silty Clay Till & 22259.57 \\
\hline
\end{tabular}

The statistical analysis of undrained shear modulus values for different types of soil are listed in Table 4-7 and the plotting of those modulus with respect to the soil type is found in Figure 4-13.

Table 4-8 Statistics evaluation of undrained shear modulus of different types of soils

\begin{tabular}{|l|c|c|c|c|c|}
\hline $\begin{array}{c}\text { Undrained } \\
\text { Modulus, (kPa) }\end{array}$ & Clay & Clayey Silt & Clayey Silt till & Silty Clay & Silty Clay Till \\
\hline Minimum & 10902.95 & 2982.74 & 1526.03 & 2102.35 & 1616.30 \\
\hline Maximum & 119544.90 & 97643.34 & 158152.18 & 149051.44 & 167059.24 \\
\hline Average & 55588.47 & 49918.34 & 28462.62 & 41419.17 & 24489.26 \\
\hline
\end{tabular}

The Table 4-8 above shows the variation in modulus according to the soil types and their higher and lower values along with the mean. All the soil type have large variation in the minimum and maximum values and the average values for Clayey Silt and the Silty Clay have more close to each other and also the average value of Silty Clay Till and Clayey Silt Till have similar. The clay have large variation and also the mean modulus is higher than other types of soil. 


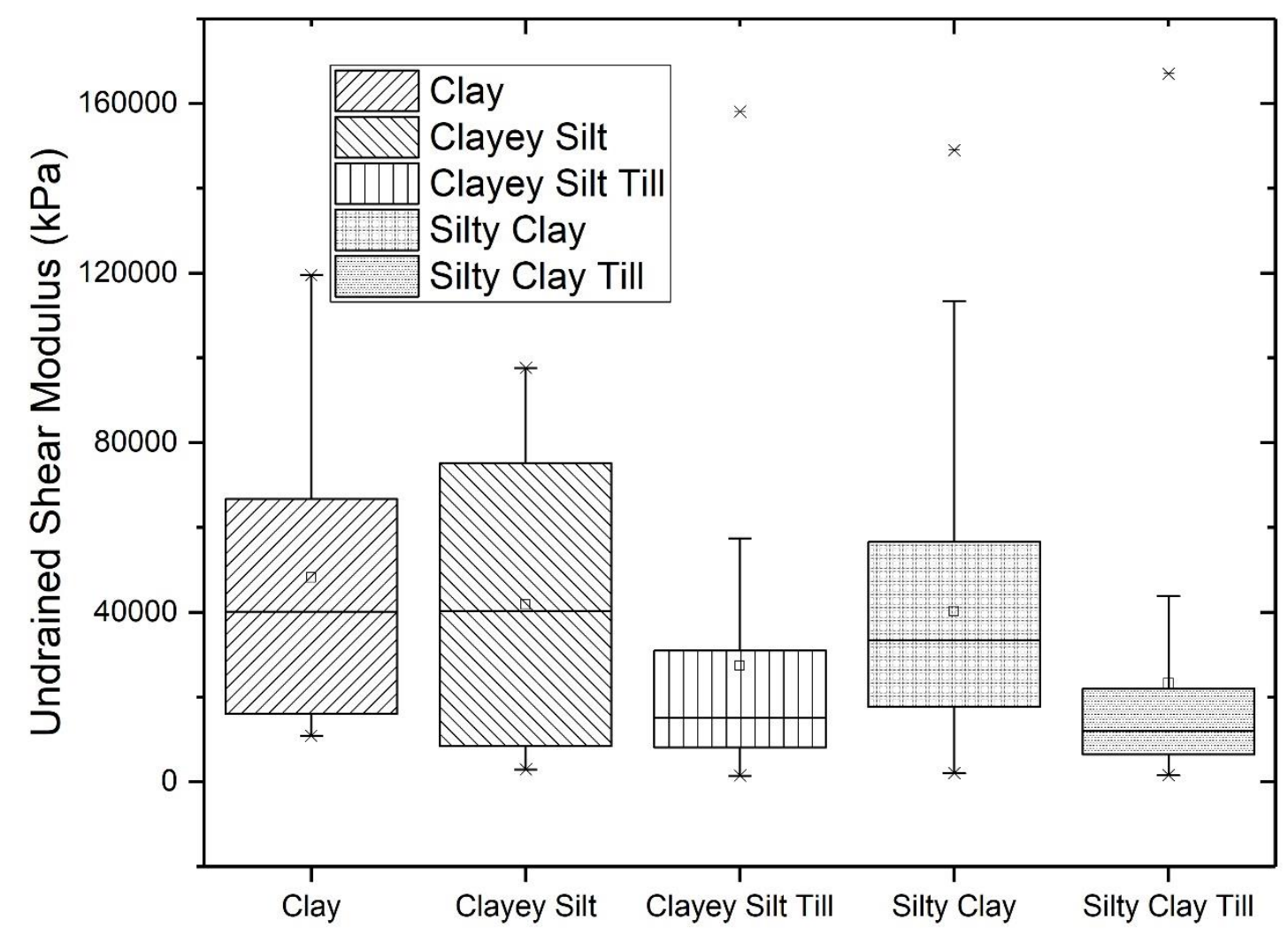

Figure 4-14 The undrained shear modulus of different types of soil from GTA

The undrained soil modulus of clay is highly variable and this is due to the moisture content and the grain orientation. The lower water content on soil is stiffer and that will ultimately effect the undrained modulus of the soil. Not only the Clay, other soil types have large variation in undrained modulus ranging from 2MPa to $167 \mathrm{MPa}$. It can be observed that Clayey Silt Till and Silty Clay Tills overall modulus have higher level of agreement if we exclude some of outliers (highest values) from the data. The Clayey Silt have its $50 \%$ of the distribution is close to the mean value of the undrained modulus.

\subsubsection{Over Consolidation Ratio (OCR)}

The glacial deposits of GTA are usually overconsolidated and therefore the OCR values are greater than 1. In fact it is assumed that the presence of overburden during the deposition gives impacts on the upper part of soil showing highly overconsolidation ratio and their preconsolidation pressure 
can be approximated multiplying by the specific weight of thickness of ice sheet. However, it is difficult to determine consolidation state of glacial till.

Settlement of the soil material is one of the most important parameter for the construction of any structure in geotechnical engineering. Both rate and amount of settlement need to consider while constructing any structure. The excess settlement would lead other consequences, like broken utilities and/or appearances of cracks in the building. Whereas the fast settlement rate is more dangerous and have less time to address corrective measures.

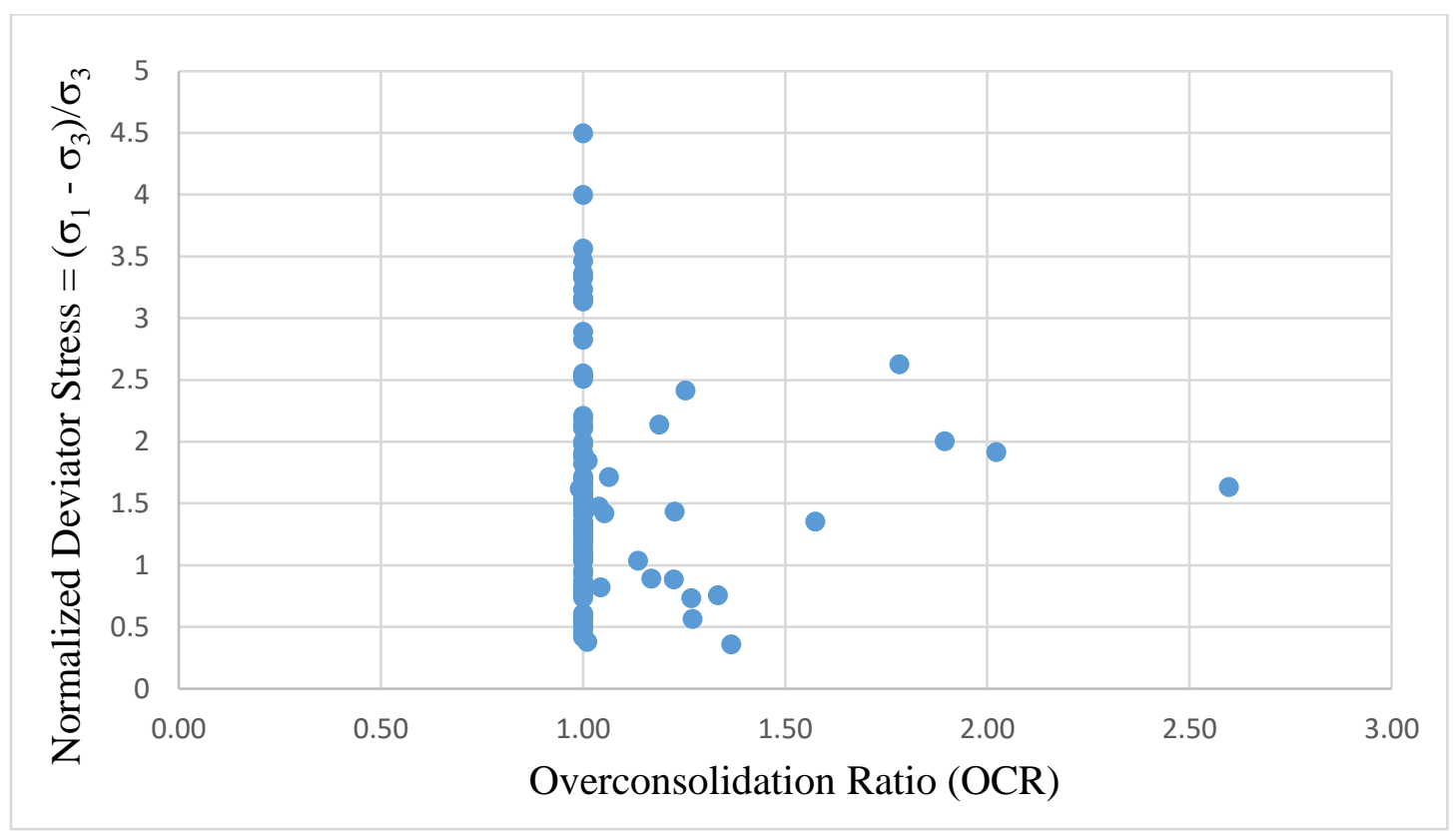

Figure 4-15 Relationship between OCR and the normalized deviator stress of GTA

The triaxial test and the one dimensional consolidation test conducted in different LRT stations are compiled and the overconsolidation ratio is calculated. In most of the case the confining pressure is higher than the preconsolidation pressure estimated from the Oedometer tests. In this case the overconsolidation value 1 is used. Otherwise, the OCR is calculated as the ratio of preconsolidation over the confining pressure during sample consolidation stage. The normalized deviator stress, $\left(\sigma_{1}-\sigma_{3}\right) / \sigma_{3}$ is presented against the OCR, shown in Figure 4-15. There is no clear trend that can be observed from this relationship. 


\subsection{STATISTICAL METHOD}

The investigation primarily depends on the sample size which ultimately effect on the content, representativeness, and accuracy. The statistical analysis of test results (descriptive statistics) and estimation from sample to population (deductive statistic) allow verification of the survey results. If the statistical methods are applied the probability should not exceed 5\% of limit state even in worse case. In this regards the estimation of mean of the set of geotechnical parameters corresponds with mean of $95 \%$ confidence level. Sometimes the local failure cannot be excluded and estimation should be done cautiously with lower value corresponding 5\% fractile.

\subsubsection{Descriptive Statistics}

The descriptive statistics is used to describe the data set or sample of it. The descriptive statistics is the heart (meaningful and useful) of all quantitative analysis. Primarily it can divide into central tendency and variability measurement. The mean, median and mode are measures the central tendency and the standard deviation or variance, the minimum and maximum variables, the kurtosis and skewness are the measure of variability.

The soil properties also show compliance on the normal distribution and are favorable to every linear combination of normally distributed values. So the summation of two or more normally distributed parameters within a linear relationship, the resultant would be distributed normally. If the number of sample is $n$ and $x_{i}$ is distribution function then the normal distribution of arithmetical mean:

$\bar{x}=\left(\sum x i\right) / n$

and the standard deviation: $\quad \sqrt{\frac{1}{n-1} \sum_{i=1}^{n}(x i-\bar{x}) 2}$

The most commonly used distribution is normal or log normal distribution and their compliance is already satisfied. On the other hand, depending on the soil parameter more complex distributions could be used to analyze, such as the Gumbel distribution or Weibull distribution and gives better compliance on the derived values. In geotechnical investigation most of the analyses are confined in these two simple distributions and the compliance of distribution are verified either by visually or using the test of goodness of fit. 
Table 4-9 Showing the descriptive statistics of the data for triaxial test

\begin{tabular}{|l|c|c|c|c|c|c|}
\hline & $\begin{array}{c}\text { Water } \\
\text { content } \\
(\%)\end{array}$ & $\begin{array}{c}\text { WL } \\
(\%)\end{array}$ & $\begin{array}{c}\text { WP } \\
(\%)\end{array}$ & $\begin{array}{c}\text { Unit } \\
\text { Weight } \\
\mathrm{kN} / \mathrm{m}^{3}\end{array}$ & $\begin{array}{c}\text { Friction } \\
\text { angle (max } \\
\text { Dev Stress) } \\
\text { degrees }\end{array}$ & $\begin{array}{c}\text { Friction angle } \\
\text { (max stress } \\
\text { ratio) degrees }\end{array}$ \\
\hline Mean & 17.72 & 28.03 & 16.97 & 21.65 & 26.96 & 27.53 \\
\hline Standard Error & 0.89 & 1.41 & 0.71 & 0.19 & 0.47 & 0.50 \\
\hline Median & 14.70 & 25.00 & 16.00 & 22.20 & 27.46 & 28.27 \\
\hline Mode & 11.90 & 20.00 & 22.00 & 23.20 & \#N/A & \#N/A \\
\hline Standard Deviation & 6.84 & 10.86 & 5.43 & 1.45 & 3.58 & 3.81 \\
\hline Sample Variance & 46.78 & 117.85 & 29.54 & 2.11 & 12.81 & 14.54 \\
\hline Range & 25.60 & 53.00 & 23.00 & 5.60 & 16.21 & 16.66 \\
\hline Number of Data Point & 59 & 59 & 59 & 59 & 58 & 58 \\
\hline Minimum & 7.70 & 16.00 & 9.00 & 18.40 & 18.05 & 18.60 \\
\hline Maximum & 33.30 & 69.00 & 32.00 & 24.00 & 34.26 & 35.26 \\
\hline Count & 59 & 59 & 59 & 59 & 59 & 59 \\
\hline Confidence Level (95\%) & 1.78 & 2.83 & 1.42 & 0.38 & 0.94 & 1.00 \\
\hline
\end{tabular}

The table 4-9 summarizes all five different types of parameter of glacial till of GTA. The minimum and maximum value gives the range. The mean is the average of the total data points. The minimum and maximum values are representing the values and used to find range. The confidence level gives how much the variation in the data and if the value is lower than this value will be lower, higher the value of confidence level means there are wide variation in the values. The mode is the repetitive value in the sample. 


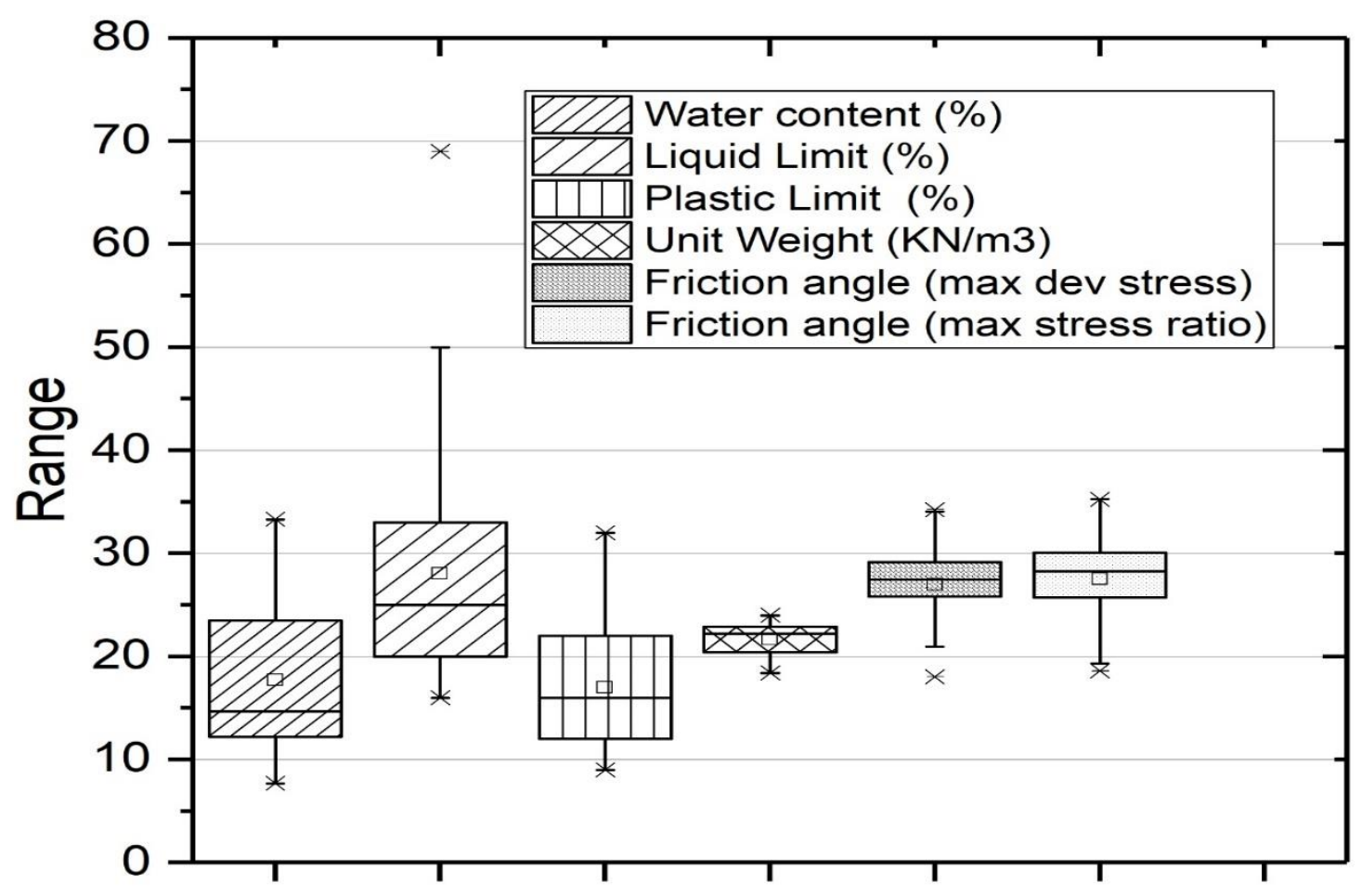

Figure 4-16 Various parameter of the soil and their range

From the Figure 4-16, it is observed that the soil have different range of various parameters. The water content and liquid limit have wide range, whereas the plastic limit have relatively low range. Although there are different soil types found in the area with very less variation in their unit weights. The friction angle have little wide variation than that of unit weight and ranges from 18 degrees to 34 degrees.

\subsubsection{Test of Goodness of Fit to Normality}

The test of goodness of fit measures how well the observed distribution fitted with the actual distribution. If both distribution gives almost same or visually fitted, then the tested distribution has higher fitting. There are different methods for the analysis of test of goodness of fit. The widely used methods for test of goodness are; the chi-square, the Kolmogorov-Smirnov (or K-S), the Shapiro-Wilk and the Anderson-Darling (or A-D) methods. Any one of these methods can be used to validate the specified distribution model and if two or more distributions are more acceptable then the same test may be used to determine higher acceptable model. The chi-square test of 
goodness of fit is primarily use for the categorical data whereas the Shapiro-Wilk and the Kolmogorov-Smirnov can use for continuous data.

The Shapiro-Wilk normality test was evaluated through visual methods. This normality test is generally most powerful test in case of sample size less than 50 (Razali and Wah, 2011). Although our case the sample size is higher than 50 we use Shapiro-Wilk method to test the normality. In this method the distribution was investigated through histogram, Q-Q plots and box plots. The normal distribution is termed when the distribution is equal to a Gaussian distribution.

Figure 4-17 compares different parameter and their significance level using Shapiro-Wilk method of analysis. A significance level is set higher than 5\% indicates that the sample is normally distributed, whereas the lower than $5 \%$ shows the hypothesis is not normally distributed.

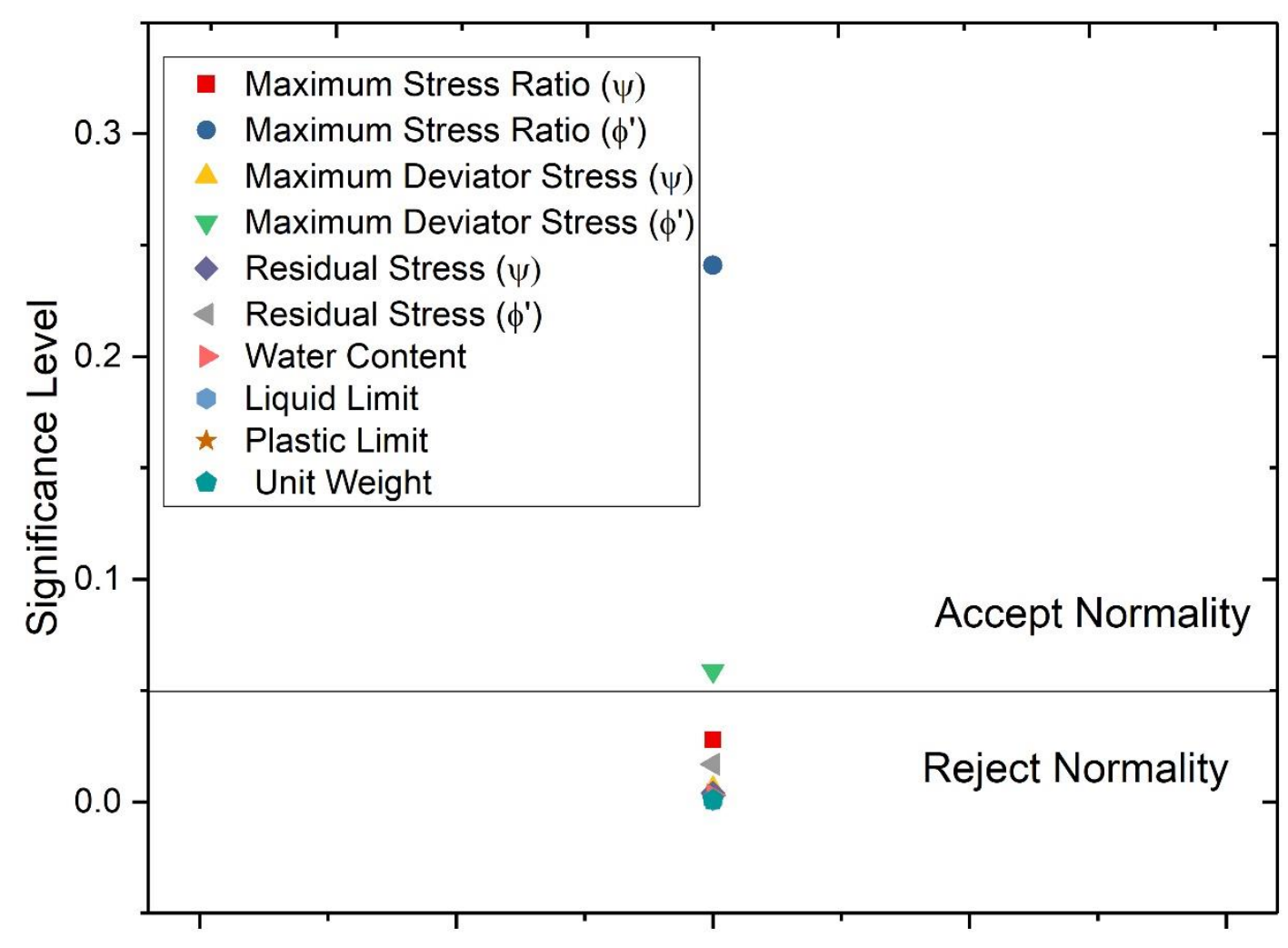

Figure 4-17 Significance level for various parameter of the soil according to Shapiro-Wilk test 
Figure 4-17 shows that only 2 parameter the friction angle $\left(\phi^{\prime}\right)$ on both maximum stress ratio and maximum deviator stress are normally distributed, whereas all other parameter do not show any normal distribution. The line value 0.05 separates weather the data are normally distributed or not as we set the significance level 95\%. The values above this line represents the data are normally distributed whereas lower than 0.05 value do not show normal distribution.

\subsection{SUMMARY}

There are 59 sets of triaxial tests were conducted and different parameters were calculated and analyzed statistically. The soil type and the stress path analysis gives the slope angle always higher in maximum stress ratio for all soil types. The relation of shear strength with the soil depth does not show any relations. The soil type and the friction angle in soil type Clayey Silt Till and Clayey Silt have less variation whereas other 3 soil types have wide variation. The undrained shear modulus is depends on the elasticity or stiffness of the soil and analysis shows that there is wide range.

The unit weight have very less variation whereas the liquid limit of soil have large variation. The friction angle in terms of maximum deviator stress and based on maximum stress ratio have similar range. From this statistical analysis, we can see how much the variation in the properties of soil. This variation can be used to estimate possible uncertainties in the soil. The goodness of fit in terms of friction angle $\left(\phi^{\prime}\right)$ shows normal distribution in both the case of maximum stress ratio and maximum deviator stress, whereas all other parameter including; liquid limit, plastic limit, unit weight, and friction angle $(\psi)$ from maximum stress ratio, maximum deviator stress and residual stress does not follow normal distribution. 


\section{CHAPTER 5 SUMMARY AND CONCLUSION}

\subsection{SUMMARY}

There is no any correlation of different failure criteria have been carried out in fine grained soil of GTA. In present study, I compared two soil failure criteria on triaxial test i.e. maximum deviator stress and the maximum deviator stress. The raw data of triaxial tests have been processed to study the shear strength parameters of fine-grained tills in the GTA. The soils of the GTA were deposited by glacier activities. Initially, this area was covered by thick ice experiencing heavy stress loading states. Due to melting down of ice sheet, the area is now at stress relax stage and the behavior of soil is uncertain. In most of the cases, the shear strength and present overburden stress does not show any correlation. Due to the nature of the deposit the soils at GTA have large inhomogeneity, so it should be considered and take caution while dealing the soil and its properties. The large variation in the grain sizes also a clear indicator of soil inhomogeneity. Different soil types have different characteristics in response of different geotechnical parameters. The soil type, soil depth, shear angle, friction angle, undrained shear modulus and overconsolidation ratio is also differ due to spatial variability and past stress history. There are different failure criterion including residual stress, maximum stress ratio and maximum deviator stress have been calculated and presented. Based on the test results, the following conclusions can be drawn.

\subsection{CONCLUSION}

From the soil sample analysis using triaxial test data have many conclusions can derive. There are five different fine grained soil types in the study area based on the TTC classification; they are Clay, Silty Clay, Clayey Silt, Silty Clay Till, and Clayey Silt Till.

The different failure criteria, the maximum stress ratio, the maximum deviator stress, or the residual stress methods are close to each other in terms of calculation of friction angle, whereas the cohesion has wide differences. The friction angle calculated using the maximum stress ratio method ranges from 18.6 to 35.26 degrees. The mean and standard deviation of friction angle are 27.45 and 3.83 respectively. While considering the maximum deviator stress method the value ranges from 18.5 to 34.26 degree and their mean value is 26.93 and standard deviation is 3.56 . These data are not normally distributed. 
The relation between the shear stress and normal effective stress at the maximum stress ratio shows the best fit line has an average 31.8 degrees inclination, whereas the plotting by maximum deviator stress method shows the slope is 30.8 degrees. The best fit line from the maximum stress ratio and the maximum deviator stress of each soil type shows the slope angle is always higher in maximum stress ratio.

The range of shear angle values varies in different soil types. Clayey Silt till and Clayey Silt have very less variation and ranges from 26 to 32 and 26 to 31 respectively, whereas a large variation was observed in the friction angle of other 3 type of soils.

It is supposed that the increasing depth will also effect on the shear angle of the soil below ground but in case of GTA and our calculation the soil depth and the shear angle does not show any correlation. It may be due to low stress variation in this study compared to the magnitude of preconsolidation pressure. It may also be due to glacial retreat and advances. After the melting of ice the behavior of soil changes and may not show any relations.

The undrained shear modulus is one of the major properties of the soil and the failure strain indicates the soil's stiffness or dilatency. There is a wide variation in undrained shear modulus in different soil types ranging from $1.526 \mathrm{MPa}$ to $167 \mathrm{MPa}$ with an average value of $34 \mathrm{MPa}$. The mean of the undrained modulus is $33.785 \mathrm{MPa}$ and standard deviation is $33.774 \mathrm{MPa}$. Normal distribution is not observed in these data.

It is observed that soil is overconsolidated in most cases through the observation of the development of excess pore pressure and deviator stress during shearing.

\subsection{LIMITATION OF THIS RESEARCH}

Present study have some limitations. The number of sampling is one of the limitations. The limited number of data cannot use to derive any conclusions which may apply for the future study. As the test data were obtained from secondary source there is also uncertainty on test procedures. The most important limitation is the complex behavior of the soil. 


\subsection{FUTURE RESEARCH}

This study achieves its scope by calculating the soil shear strength and analyzing it statistically. However, a more comprehensive study will require supporting the result of this study.

1. The correlation with the other factors involves large uncertainties as presented by many researchers. Therefore other parameter should use to calculate shear strength is still needed another study.

2. The shear strength can also analyzed using finite element analysis as a part of future research.

3. The method of determination of failure on the soil needs more study and can be part of future research.

4. The correlation of field stress condition and the confining pressure used for the triaxial test analysis should be taken consideration for future research, as this is most important to obtain overconsolidation ratio. 


\section{REFERENCES}

ASTM D 2488-00 (2000), Standard Practice for Description and Identification of Soils (VisualManual Procedure), ASTM International, West Conshohocken

Baecher, G. B. and J. T. Christian (2003). Reliability and statistics in geotechnical engineering, New York: John Wiley \& Sons.

Baker, C.L., Lahti, L.R., and Roumbanis, D.C. (1998), Urban Geology of Toronto and surrounding area. Urban Geology of Canadian Cities. Edited by: P.F. Karrow, 42, 323-352.

Boone, S. J., Shirlaw, J.N. et al. (1996), Boulder assessment report for TTC Sheppard Subway, Golder associates report no: S-GIR3-R. Toronto.

DiMaggio, J., Saad, T., Allen T., Christopher, B. R., Dimillio, A., Goble, G., Passe P., Shike, T. \& Person, G. (1999), Geotechnical engineering practices in Canada and Europe. Report FHWAPL-99-O, Federal Highway Administration (FHWA), Washington.

Eyles, N., M. Meriano, J. Boyce.(1998), Ground water Modelling and Urban Planning: A Joint University of Toronto/City of Scarborough Initiative, Phase 1 Report: Hydrogeology of The City of Scarborough and The Surrounding Rouge River-Highland Creek Watershed Area. Draft, January 1998.

Fredlund, D.G., N. R. Morgenstern, and R. A. Widger, (1978), Shear strength of unsaturated soils. Canadian Geotech Journal 15: 313-321

GDS, Introduction to triaxial testing by Dr. Sean Rees, www.gdsinstruments.com

Georgiannou, V.N., Burland, J.B., (2001), A laboratory study of post-rupture strength. Géotechnique 51 (8), 665-675

Green, R. \& Becker, D. (2001), National report on limit state design in geotechnical engineering: Canada. Geotechnical News, 19(3): 47-55.

Goble, G. (1999), Geotechnical related development and implementation of load and resistance factor design (LRFD) methods. NCHRP Synthesis 276, Transportation Research Board, Washington. 
Henkel, D. J. (1959), The Relationship between the strength, pore-water pressure, and volume change characteristics of saturated clays. Geotechnique, 9(3): 119-135.

Karrow, P.F. (1967), Pleistocene geology of the Scarborough area. Ontario department of mines, Geological reports 46

Karrow, P.F. and White, O.L. (1998), Urban geology of Canadian cities, Geological association of Canada, GAC special paper 42

Laifa Cao, Scott Peaker \& Shaheen Ahmad (2015), Engineering characteristic of glacial tills in GTA, Geo Quebec, September 20-23, Quebec

Lee, K. L. \& Seed, H. B. (1967), Drained strength characteristics of sands. J. Soil Mech. Fdns Div. Am. Sot. Civ. Engrs 93, SM6, 117-141.

Manzari, M., Drevininkas, A., Olshansky, D. and Galaa, A. (2014), Behavioral modelling of Toronto glacial soils and implementation in numerical modeling. 67th Canadian Geotechnical Conference, Geo Regina.

Mayne, P. W., (1985), A review of undrained strength in direct simple shear, Soils and Foundations, Vol. 25, No. 3, 64-72

Ministry of Transportation Ontario (1992), Ontario Highway Bridge Design Code and Commentary (OHBDC3), 3rd Ed., Downsview, Ontario

Murthy, K., Sridharan, A. and Nagaraj, T.S. (1981), Shear strength behavior of overconsolidated clays. Soils and Foundations, Japanese Society of Soil Mechanics and Foundation Engineering, 21(2): 73-83.

Parry, R. H. G. and Nadarajah, V. (1973), Observation on laboratory prepared, lightly overconsolidated specimens of kaolin. Geotechnique, 24(3): 345-358.

Ramanatha Iyer, T.S. (1975), The behavior of Drammen plastic clay under low effective stresses, Canadian Geotechnical Journal, 12(1): 70-83. 
Razali, N. M. and Wah, Y. B. (2011), Power comparisons of Shapiro-Wilk, Kolmogorov-Smirnov, Lilliefors and Anderson-Darling tests, Journal of Statistical Modeling and Analytics, 2(1): 21-33.

Roscoe, K. H., Schofield, A. N., and Wroth, C. P. (1958), On the yielding of soils. Geotechnique, 8(1): 22-53.

Roscoe K. H. and Burland J. B. (1968), On the generalized stress-strain behavior of 'wet' clay, Engineering Plasticity (edited by J. Heyman and F.A. Leckie), Cambridge University Press: 535609.

Sharpe D.R., (1980), Quaternary Geology of Toronto and Surrounding Area; Ontario Geological Survey Preliminary Map P. 2204, Geological Series.

Sharpe, D.R., Barnett, P. J. et al. (1999). Regional Geological Mapping of Oak Ridges Moraine Greater Toronto Area -Southern Ontario, in current research 1999-E, Geological Survey of Canada, pp 123-136.

Simons, N. E. (1960b), Comprehensive investigation of the shear strength of an undisturbed Drammen clay. Proc. ASCE Research Conf. on Shear Strength of Cohesive Soils, Boulder, Co, pp 727-743.

Skempton, A. W., (1948b), “The Geotechnical Properties of a Deep Stratum of Post-Glacial Clay at Gosport", Proceedings of the second International Conference on Soil Mechanics and Foundation Engineering, Rotterdam, Volume 1, June performed an unconsolidated undrained test1948, pp 145-150.

Skempton, A.W. (1954), The pore pressure coefficients A and B. Geotechnique 4:143-147.

SPL Consultants Limited., (2013), Geo-Engineering Factual Data Report For Pre-Afp Design Don Mills Station Metrolinx, Rapid Transit Implementation With Metrolinx Toronto, Ontario, 243p.

Bishop, A.W. (1954), The use of pore pressure coefficients in practice. Geotechnique 4:148-152.

Symes M J Gens A Hight D W (1984), Undrained anisotropy and principal stress rotation in saturated sand Geotechnique 34, No. 1, pp 11-27 
Terzaghi, K (1920), Old Earth Pressure Theories, and New Test Results, Engineering NewsRecord, vol. 85, n. 14, pp. 632-637

Terzaghi, K. and Peck, R.B. (1967), Soil mechanics in engineering practice, second edition, John Wiley and Sons, New York, 729p.

Terzaghi, K., Peck, R. and Mesri, G. (1996), Soil Mechanics in Engineering Practice, Wiley \& Sons.

Tsai, J. I. (1985), Three-dimensional behavior of remolded overconsolidated clay, Ph.D. thesis University of California at Los Angeles. 